\title{
UPSTREAM PASSAGE, SPAWNING, AND STOCK IDENTIFICATION OF FALL CHINOOK SALMON IN THE SNAKE RIVER, 1992
}

Annual Report FY 92-93

Edited by

H. Lee Blankenship and Glen W. Mendel Washington Department of Fisheries

\author{
Prepared for \\ U.S. Department of Energy \\ Bonneville Power Administration \\ Division of Fish and Wildlife \\ P.O. Box 3621 \\ Portland, Oregon 97208-3621
}

Project No. 92-046

Contract No. DE-BI 79-92 BP60415

December 1993 


\section{TABLE OF CONTENTS}

TABI E OF CONTENTS $\ldots \ldots \ldots \ldots \ldots \ldots \ldots \ldots \ldots \ldots \ldots \ldots$ ii

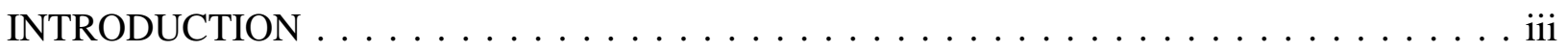
CHAPTER ONE UPSTREAM PASSAGE AND SPAWNING OF FALL CHINOOK SALMON IN THE S N A K E R I V E R . . . . . . . . . . . . . . . . . . . . . . . . . 1

CHAPTER 2

STOCK IDENTIFICATION OF SNAKE RIVER FALL CHINOOK SALMON . . . 62 


\section{INTRODUCTION}

Intensive monitoring of returning Snake River fall chinook salmon has been a coordinated effort over the last several years. The cooperating entities were the Washington Department of Fisheries (WDF), Oregon Department of Fish and Wildlife, Vez Perce Tribe (NPT), Idaho Power Company (IPC), U.S. Fish and Wildlife Service (USFWS), National Marine Fisheries Service (NMFS), U.S. Army Corps of Engineers, and Columbia River Inter-Tribal Fish Commission. Bonneville Power Administration (BPA) has provided funds and coordination activities. In addition, the Lower Snake River Fish and Wildlife Compensation Program (LSRCP) collected and analyzed genetic data which described the genetic relationships of Lyons Ferry Hatchery (LFH) fall chinook and mid-Columbia upriver bright fall chinook through 1990 (Bugert et al. 1990).

When these fish were petitioned for listing under the Endangered Species Act (ESA), three major questions were left unanswered:

1. What is the fate of 50 percent of the adults that have not been accounted for each year between the counting windows at the first dam on the lower Snake River, Ice Harbor Dam (IHR) and when they were counted as they passed the fourth dam, Lower Granite (LGR)? Potential reasons for this discrepancy include fallback at dams, spawning in the lower Snake River, or pre-spawning mortality.

3. Why do redd counts (observed by helicopter survey) on the spawning grounds above LGR in recent years average only one redd per 8.5 adults passing the dam? As with dam counts, questions remain regarding the accountability of salmon upstream of LGR, and the possibility of deep-water spawning and/or differential spatial spawning distribution between wild fish and hatchery strays.

3. What is the stock composition or genetic profile of returning adults and their offspring above LGR, and how much hatchery straying is occurring?

A study was designed in 1991 by WDF, in cooperation with the USFWS and Idaho Cooperative Fish and Wildlife Research Unit (ICFWRU) to answer these questions. Funding was provided that year by the NMFS, LSRCP, and WDF. Bonneville Power Administration provided funding the second year. This report describes the activities and results obtained during 1992.

Two separate but coordinated methodologies were used in this study. These methodologies included radio telemetry to address the questions (one and two) of salmon disposition and accountability while stock identification techniques were used to address the question regarding stock composition.

We arranged this annual report into two self-contained chapters entitled:

1) Upstream Passage and Spawning of Fall Chinook Salmon in the Snake River

2) Stock Identification of Snake River Fall Chinook Salmon 


\title{
CHAPTER ONE
}

\section{UPSTREAM PASSAGE AND SPAWNING OF FALL CHINOOK SALMON IN THE SNAKE RIVER}

\author{
by \\ Glen Mendel \\ Deborah Milks \\ Michelle Clizer \\ Robert Bugert
}

\author{
Washington Department of Fisheries \\ Salmon Culture Division \\ Olympia, Washington 98504-3 154
}

December 1993 


\section{Acknowledgements}

This project is truly a cooperative effort with several other projects. We thank the many individuals that assisted us with this study.

We thank Dr. Ted Bjornn, Rudy Ringe, Joel Hunt, Ken Tolotti, Pat Keniry, Marc Petersen, and other members of the University of Idaho, ICFWRU. They provided over 400,000 records of relocations at their fixed-site receivers, and ICFWRU personnel assisted us by tagging salmon at Ice Harbor Dam. Their cooperation and assistance benefitted this project and made completion of our tasks much easier. Their assistance is very much appreciated.

We thank Jerry Harmon, Neil Paasch, Ken Thomas, and Ken McIntyre (NMFS) for their valuable assistance trapping and tagging fall chinook salmon for us at Lower Granite Dam.

They were extremely cooperative and accommodated our needs.

Phil Groves and Chris Randolph of Idaho Power Company assisted by providing funding for several helicopter flights for redd counts and radio telemetry. We appreciate their contributions to this project.

Billy Connors, Aaron Garcia, and others at the USFWS Fishery Resource Office assisted with radio tracking by providing funding for cooperative flights and assisting us during boat tracking efforts. They also assisted with carcass and radio tag recovery.

We wish to specifically thank Steve Reed, Skyrunners Corporation, and Jim Pope, Sr., Valley Helicopter, for providing many safe, productive telemetry flights.

We appreciate the assistance of Lance Ross, Jerry Dedloff, Greg Fullerton, Christine Knostman, Homer Colson, Mike Varney, Bill Massey, Mark Lambert, Byron Wenning, Mike Deitchler, and Brian Sass (WDF) for assisting with various tasks such as trapping, hauling, tracking, tagging, record keeping, or data entry. We also acknowledge all those individuals and organizations that returned tags and data to us.

Lee Blankenship, WDF, provided recoveries of radio tagged fish and assisted us by handling the reward system and other aspects of this study.

We thank Debbie Watkins and the Bonneville Power Administration for funding this project in 1992. We also thank Dan Herrig and Edouard Crateau, USFWS, LSRCP Office for providing funding in 1991 that initiated this three year project. Dennis Rondorff, USFWS, assisted with original development of the study plan. Debbie Watkins, Joe Krakker, Howard Fuss, Ross Fuller and Andy Appleby critically reviewed a draft of this report. 
A B S T R A C T. . . . . . . . . . . . . . . . . . . . . iii

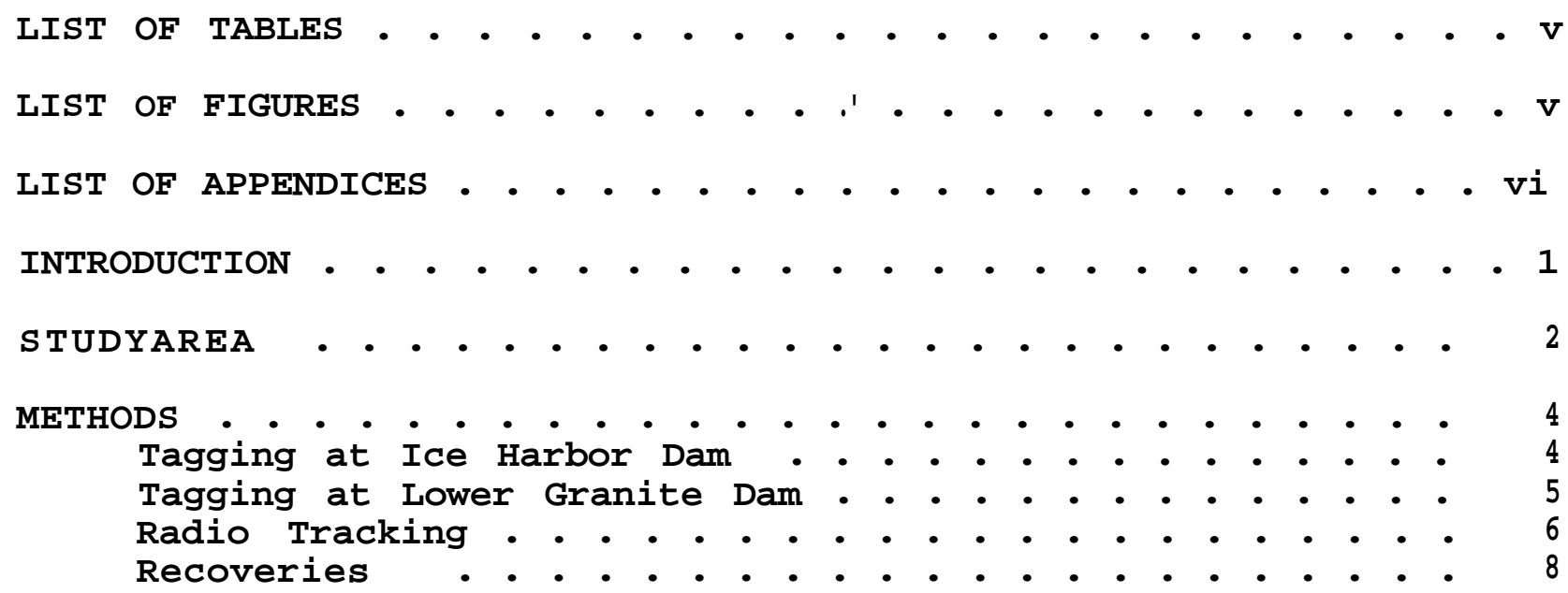

RESULTS and DISCUSSION . . . . . . . . . . . . . . . . . . . $\quad$. 8

Salmon Tagged at Ice Harbor Dam . . . . . . . . . . . . 8

Tagging efforts . . . . . . . . . . . . . . . . 8

Fish movements . . . . . . . . . . . . . . 9

Fallback . . . . . . . . . . . . . . 15

Interdam losses . • . . . . . . . . . . . . 17

Salmon Tagged at Lower Granite Dam . . . . . . . . . . 18

Tagging efforts . . . . . . . . . . . . . 18

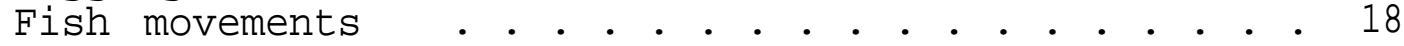

Radio Tagged Salmon From all Releases . . . . . . . . . 19

Interdam Losses Upstream of LGR Dam . • . . . . . 19

Spawning • • • • • • • • • • • • • • • • • • • • . 20

Fall back by radio tagged salmon . . . . . . . . 21

Loss of Tags . • . . . . . . . . . . . . . 22

CONCLUSIONS . . . . . . . . . . . . . . . . . . . . . . . . . 24

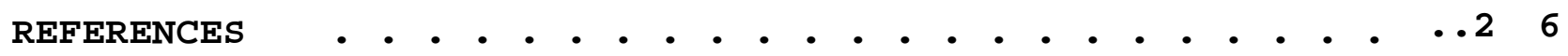

APPENDICES . . . . . . . . . . . . . . . . . . . . . . . 28 


\section{ABSTRACT}

This report summarizes our activities and results for the second year (1992) of a three year study. A summary of our 1991 activities and results was reported previously (Mendel et al. 1992). The goals of our study were as follows: 1) to determine the source(s) of interdam losses of adult fall chinook salmon between Ice Harbor Dam (IHR) and Lower Granite Dam (LGR), as well as upstream of LGR; 2) identify spawning locations upstream of LGR for calibration of aerial redd surveys, and to assist with redd habitat mapping and carcass recovery (for genetic stock profile analysis).

Radio telemetry was used as our method of addressing project goals. Unmarked (not adipose clipped) adult fall chinook salmon were trapped and radio tagged at IHR and LGR dams as they ascended the snake River during their spawning migration. We used aerial and ground mobile radio tracking to determine the movements of these fish.

A total of 96 fall chinook salmon were radio tagged and released near IHR Dam. Fifty-three fish were released down stream of IHR at Hood Park (RR 3.7) and forty-three fish were released upstream of IHR at Charbonneau Park (RK 18.3). Three of these radio tagged fish were never relocated ( $1 \mathrm{HPK}, 2 \mathrm{CHAR}$ ), while 93 fish were radio tracked, or recovered. Fifty-eight (62.4\%) of the salmon were upstream of IHR Dam sometime after being radio tagged. The other 35 (37.6\%) fish we tracked descended the Snake River and moved to the Columbia or Yakima rivers. Seventeen of the 58 radio tagged salmon upstream of IHR crossed LGR, and another 10 fish entered Lyons Ferry Hatchery.

Several other fish fell back at Snake River dams and descended to the Columbia River. Fall back by radio tagged salmon was common at all Snake River dams. Fall back was also documented for untagged fall chinook salmon at LGR and Little Goose (LGO) dams on the Snake River (unpublished data from the Corps of Engineers and the University of Idaho).

We were able to account for 50\% of the radio tagged salmon between IHR and LGR using summation methods that we commonly use to account for untagged fall chinook salmon. We were able to document with radio telemetry that $62.1 \%$ of the salmon that we could not account for with the standard summation method had fallen back at IHR Dam and descended to the Columbia or Yakima rivers. Several other fish were last located within the reservoirs. We were unable to determine the fate of these "lost" fish.

An additional twenty fall chinook salmon were radio tagged and released at the adult trap at LGR Dam. We were able to obtain at least some relocations of all 20 radio tagged salmon. 
Six of these fish fell back at LGR, another two fish were "lost" at the dam or in the reservoir. Twelve other fish-were relocated in the Clearwater, Salmon, Grande Ronde or upper Snake rivers.

We examined movements of all radio tagged salmon upstream of LGR Dam. That provided us with a sample of 17 radio tagged fish tagged at IHR and 20 tagged at LGR. We estimate a combined fall back rate at LGR of 37.1\% (13 fish). Another 10.8-13.5\% were "LOST" or prespawning mortalities. We identified two potential spawning locations that would not have been detected from the aerial spawning surveys. One site was upstream of Troy on the Grande Ronde River and the other was in the upper Snake River.

The adult-per-redd ratio upstream of LGR was 8.2 in 1992, similar to the average for previous years. However, if we reduce the number of adult salmon counted past LGR by $35 \%$ to account for fall back at the dam, and reduced that by another $10.8 \%$ for "lost" fish, we obtain an estimate of 4.7 adults-per-redd.

Although fall back at dams was common, we were unable to positively determine the routes of descent. However, we believe that most fish fell back through the turbine intakes. Estimates of survival were 86.2-94\% for fish falling back through dams.

We believe there is evidence that movements of our radio tagged salmon represent the movements of untagged fall chinook salmon. Based on the recovery of a tagged salmon, we recommend that spawning surveys be extended upstream of Troy on the Grande Ronde River. Most importantly, we find that ladder counts of fall chinook salmon passing IHR and LGR dams provide inflated estimates of the number of this federally listed (threatened) salmon available to spawn within the snake River Basin. 


\section{LIST OF TABLES}

Page

Table 1. Summary of fall back events at lower snake River dams by radio tagged fall chinook salmon, 1992. Data are presented to indicate those fall backs that occurred prior to the date spawning is likely to have occurred (prior to 1 November; early spawning season). We are uncertain whether fish falling back at a dam after 31 October spawned prior to falling back. • . • 23

\section{LIST OF FIGURES}

Figure 1. General study area and locations of landmarks used in this fall chinook radio telemetry study, 1992 (inset regional map courtesy of Aaron Garcia, USFWS,

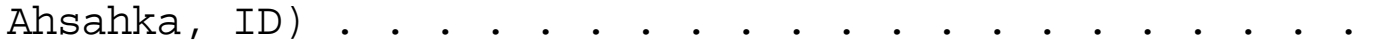

Figure 2. Fall chinook salmon run timing at Ice Harbor Dam with the distribution of salmon radio tagged,

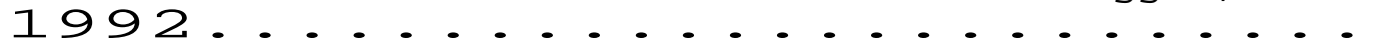

Figure 3. Numbers of radio tagged fall chinook salmon (from 96 fish released near IHR Dam) at various points in the Snake and Columbia River, 1992. Numbers in parentheses are fish that were "lost" in the reservoir or entered Lyons Ferry Hatchery (10 fish), without crossing the next dam upstream (For example, $58 \mathrm{fish}$ crossed IHR Dam, 14 fish fell back and two were lost, so 42 fish crossed LMO Dam). . . . . . . . . . . . .

Figure 4. An example of a raldio tagged salmon (chan. 1/45) that fell back after crossing LMO Dam to the Columbia

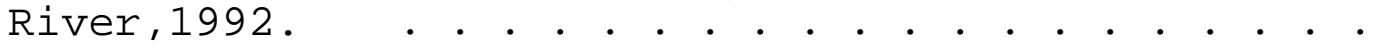

Figure 5. Movements of one of the radio tagged fall chinook salmon (chan. 2/4) that apparently spawned in the Tucannon River, 1992. . . . . . . . . . . . .

Figure 6. An example of move:ments of a radio tagged fall chinook salmon (ch. 2/45) that fell back twice at

Figure 7. Movements of a radio tagged fall chinook salmon (chan. 3/20) tagged and released near IHR Dam that crossed LGR Dam before falling back and entering Lyons Ferry Hatchery, 1992. . . . . . . . . . . . . . . . . 
Figure 8. Movements of a radio tagged fall chinook salmon (chan. 1/28) tagged and released near IHR Dam passed upstream of LGR Dam before falling back at all four lower Snake River dams. It was recovered in the sport catch in the forebay of McNary Dam on 9 October, 1992. . . 3

Figure 9. Movements of a radio tagged fall chinook salmon (chan. 2/32) that apparently did not attempt to cross IHR Dam after release, 1992. . . . . . . . . . . . .

Figure 10. Movements of a radio tagged fall chinook salmon (chan. 1/22) that demonstrates some of the wandering movements observed between the Columbia River and IHR Dam, 1992. . . . . . . . . . . . . . . . 16

Figure 11. Movements of a radio tagged fall chinook salmon (chan. 1/30) released at LGR Dam that fell back twice at LGR Dam and remained in the tailrace, 1992. . . . . 18

Figure 12. Apparent distribution of radio tagged fall chinook salmon upstream of LGR Dam in 1992. Seventeen salmon were tagged at IHR (numbers followed by asterisk) and 20 were tagged at LGR. All fish in the Snake (upstream of the Clearwater River), Grande Ronde, and Clearwater rivers apparently spawned, except two fish (one in the clearwater, and one in the lower Salmon River).

\section{LIST OF APPENDICES}

\section{AP P END I XA}

AP P END I XB

AP P ENDIXC

AP P END I XD 


\section{INTRODUCTION}

Washington Department of Fisheries (WDF) personnel annually monitor returns of fall chinook salmon to the Snake River to assess progress toward the Lower Snake River Compensation Program (LSRCP) goal of returning 18,300 adult hatchery fall chinook salmon annually to the Snake River. Over several years we noticed that approximately half the fall chinook salmon counted past Ice Harbor Dam (IHR) could not be accounted for at upstream locations (Mendel et al. 1992). We are able to obtain counts of fall chinook salmon upstream of IHR from three sources: 1) Lyons Ferry Salmon Hatchery, 2) Lower Granite Dam (LGR), or 3) spawning escapement estimates in the major tributaries (Tucannon and Palouse rivers) between IHR and LGR. We also noticed over several years that many adult fall chinook salmon could not be accounted for upstream of LGR based on cooperative redd surveys conducted by several agencies and organizations. An average adult-per-redd ratio of 8.5:1 has been estimated over several years in the late 1980's and early 1990's (Mendel et al. 1992). Disparity of salmon counts between IHR and LGR, or upstream of LGR, may be due to; 1) fall back at IHR or LGR, 2) prespawning mortality, 3) interception in jack fall chinook salmon or steelhead sport fisheries, 4) spawning in tailraces of the lower Snake River dams, or 5) an inability to detect all redds upstream of LGR Dam (Mendel et al. 1992).

Therefore, we initiated this radio telemetry study in 1991, in an effort to determine the fate of *tmissingl' fish upstream of IHR and LGR. This study is a cooperative effort with the Idaho Cooperative Fish and Wildlife Research Unit (ICFWRU) at the University of Idaho. Personnel from the ICFWRU are conducting radio telemetry studies involving spring and summer chinook salmon and steelhead in the Snake River Drainage (Bjornn et al. 1992). They assisted us by implanting radio transmitters in fall chinook salmon. We assisted them by trapping steelhead at IHR Dam, while we trapped fall chinook salmon, as well as assisting them with tagging and radio telemetry of steelhead. They provided us a substantial amount of telemetry data from their fixed-site tracking stations and mobile tracking efforts. Our radio telemetry study was also strongly interconnected with our broodstock trapping efforts for Lyons Ferry Hatchery (Mendel et al. 1992b). Several other studies were associated with our radio telemetry efforts as well. The U.S. Fish and Wildlife Service (USFWS) Fishery Resource Office at Ahsahka, Idaho, was attempting to identify and map spawning habitat for fall chinook salmon in the Snake River upstream of LGR Dam (Connor et al. 1993). Other WDF personnel (Blankenship 1993) recovered fall chinook salmon carcasses for genetic analyses and baseline stock identification. Idaho Power Company (IPC) personnel studied fall chinook salmon spawning locations and the effects of various water releases from Hells Canyon Dam (Groves 1993). Personnel from the Nez Perce Tribe and the Oregon Department of Fish and Wildlife (ODFW) 
provided flight time and assistance in locating radio tagged fall chinook salmon upstream of LGR. All of these projects were interrelated and required substantial coordination.

Briefly, the goals of our radio telemetry study were as follows (See Mendel et al. 1992 for a more detailed discussion) :

1 ) Determine the source(s) of interdam losses between IHR and LGR, and upstream of LGR.

2) Identify spawning locations upstream of LGR to assist with the following; calibration of aerial redd surveys, redd habitat mapping, salmon carcass recovery for genetic analyses, and correction of estimated adult-per-redd ratios.

This report summarizes our radio telemetry activities as well as our results and conclusions for the contract period of 1 July 1992 to 30 June 1993. This is the second year of a three year study. Further analysis of these data may be included in subsequent reports.

\section{STUDY AREA}

Initially our study area consisted of the area from the mouth of the Snake River (RK 0.0) upstream to Hells Canyon Dam (RK 397.4) the lower Clearwater River, and the lower Grande Ronde River (Figure 1). However, in 1991 we adjusted the study area to include at least that portion of the Columbia River from just downstream of McNary Dam (RK 469.8) to Priest Rapids Dam (RK 638.3). In 1992 we added the following river segments to our study area: 1) the Columbia River from McNary Dam to just below Irrigon Fish Hatchery (RK 450.5), 2) the Yakima River upstream from its mouth to Wapato Dam (RK 171.5), and the lower Salmon River (Riggins to the mouth). Common landmarks and river kilometers (RK) used in this report are listed in Appendix A.

The study area included free-flowing river segments upstream of Pasco on the Columbia River (i.e. the "Hanford Reach**), in the lower Clearwater, Salmon, and Grande Ronde rivers, portions of the Yakima and Umatilla rivers, upstream of Asotin in the Snake River, and the lower Imnaha River. Reservoirs comprised most of the remaining river segments in the snake and Columbia rivers. Short portions of the rivers below each dam retain water velocities and other characteristics similar to free-flowing river conditions. 

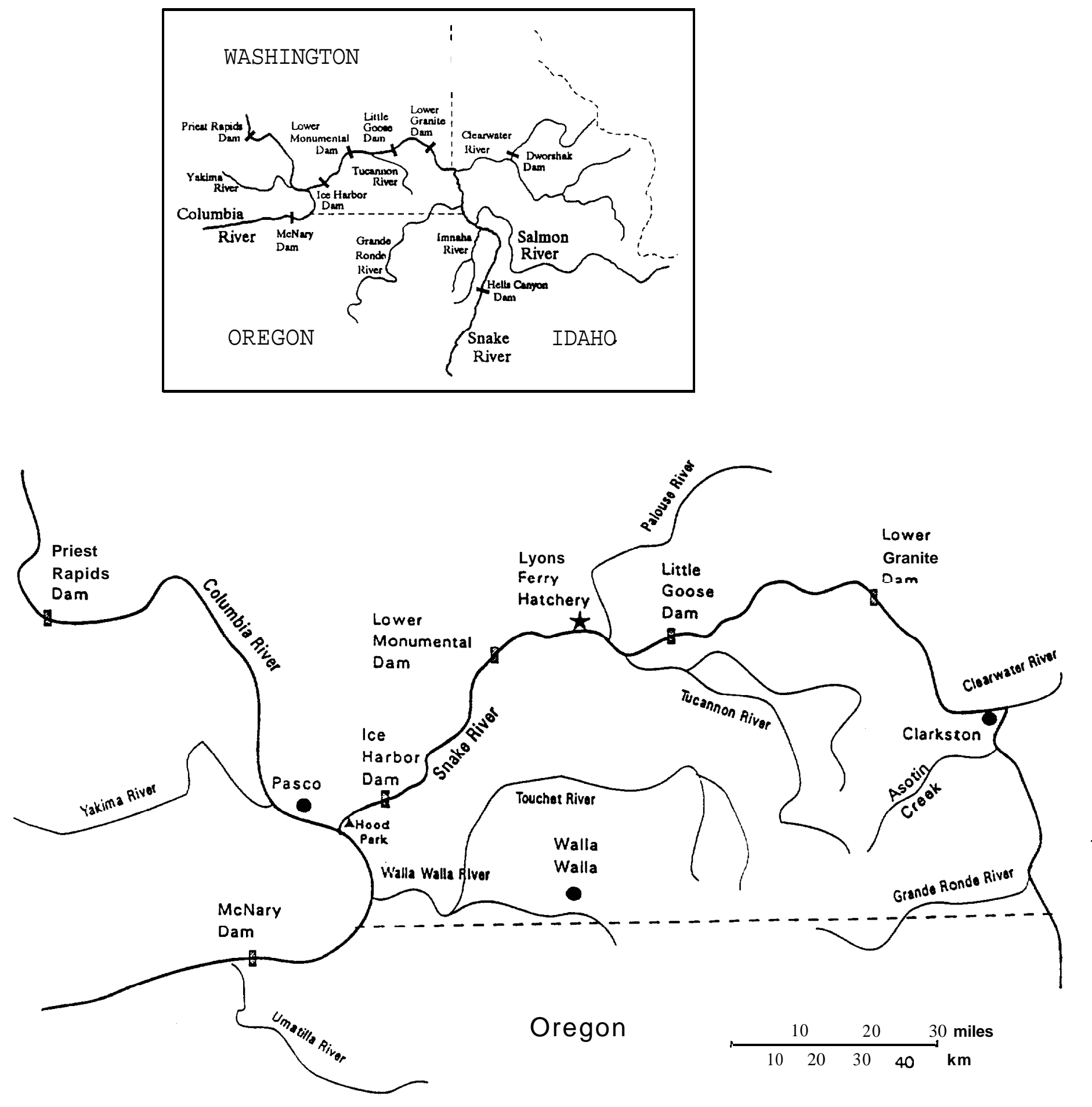

Figure 1. General study area and locations of landmarks used in this fall chinook radio telemetry study, 1992 (inset regional map courtesy of Aaron Garcia, USFWS, Ahsahka, ID). 
METHODS

Tagging at Ice Harbor Dam (IHR)

We captured fall chinook salmon in a floating trap in the upstream portion of the south shore fish ladder at IHR Dam from 31 August to 31 October 1992. The trap was operated seven days per week during daylight hours (0600-1900 hrs). We trapped salmon for broodstock for Lyons Ferry Hatchery (adipose clipped fish only) or for radio tagging (unclipped fish). Salmon were trapped for radio tagging after they were viewed through a submerged chamber in the fish trap and retained in a submerged holding pen. Details concerning fish trapping have been previously described (Mendel et al. 1992c, 1993a, 1993b, Bjornn et al. 1992).

The lower portion of the fish holding pen was constructed of sheet metal with a canvas sleeve attached to a hole in the bottom. This allowed fish to remain in water at all times and to be loaded into the transport tank without being handled. The holding tank was lifted with a crane so fish could be loaded into a $1,135 \mathrm{~L}$ tank mounted on a truck or trailer. A dilute solution of MS 222 was added to the oxygenated water in the tank. No more than 10 salmon were loaded into the truck for each tagging session, although salmon were often loaded together with steelhead.

We intended to radio tag 90 unmarked fall chinook salmon at IHR in 1992. An additional 20-30 salmon were to be radio tagged and released at LGR to increase the sample size of radio tagged salmon expected upstream of LGR.

Salmon captured for radio tagging at IHR Dam were transported to Hood Park (12.4 $\mathrm{km}$ downstream of the dam), or Charbonneau Park (2.2 km upstream of the dam). Fish were individually netted from the tank truck and placed into a $113 \mathrm{~L}$ trough with oxygenated water containing enough MS 222 to fully anesthetize them for tagging. Only salmon with a fork length greater than $65 \mathrm{~cm}$ were radio tagged because of the size of the radio transmitters (reduced in 1992 to $80 \mathrm{~mm} \times 15 \mathrm{~mm}$ ). Each fish received a uniquely numbered jaw tag attached to its left mandible. The jaw tag was attached to enable us to obtain recovery data from these fish should the fish be recaptured, or the transmitter be regurgitated. A blank-wire, or coded-wire tag was injected into the muscle just below the dorsal fin to activate the adult trap in the fish ladder at LGR (which uses a metal detector). Radio transmitters were implanted into the esophagus and stomach (inserted through the mouth to be held in place by the sphincter muscle at the top of the esophagus). After insertion, the transmitter antenna emerged from the mouth and was bent at the edge of the mouth to allow it to trail behind 
the fish's head. Fork length, sex, general condition, jaw tag number, radio frequency, and numeric code (unique to each frequency/channel) were recorded for each fish tagged. Scale samples were taken to determine fish age and provide some indication of origin. Tagged fish were individually carried in a transport bag (to calm the fish and ease transport) to a recovery pen in the river. They remained within the pen until they recovered and escaped into the river. After release the recovery pen was checked for regurgitated transmitters or jaw tags that had detached. We used recovered tags on other fall chinook salmon and adjusted our records.

We used radio transmitters and receivers manufactured by Lotek Engineering Inc., of Newmarket, Ontario, Canada. We selected this equipment because it enabled us to track large numbers of fish that could be individually identified. Also, these transmitters were compatible with the ICFWRU telemetry study equipment which enabled us to track fall chinook salmon with transmitters at ICFWRU fixed-site receiver stations. Transmitters emitted a digitally coded signal at 149 Mhz every 5 seconds. The receiver interpreted these coded signals as a unique numeric code for each frequency/channel. Up to $50 \mathrm{fish}$ with unique codes could be tracked on each frequency/channel in 1992. At least a $10 \mathrm{Khz}$ separation between each transmitter on the same channel was used to minimize overlap of signals. Upon reception of a signal from one of our transmitters the receiver produced a "chirp" sound that was not duplicated by extraneous interference. If the signal was strong enough for the code to log, the receiver would display the channel, unique numeric code, power level of the signal, date, time, and antenna number. All data were recorded manually, or stored automatically in one of eight memory banks in the receiver.

Each transmitter contained an externally visible note that listed the frequency, channel, numeric code, and notice of a reward for returning the tags to WDF at a listed address. Jaw tags also had "Reward" and our address printed on them. These notices were our effort to recover transmitters and jaw tags from the public.

\section{Tagging at Lower Granite Dam (LGR)}

We requested National Marine Fisheries Service (NMFS) personnel to assist us by capturing and radio tagging 20-30 unmarked (no wire attached and adipose fin intact) adult fall chinook salmon at the adult trap in the south shore fish ladder at LGR (see Mendel et al. 1993 for additional information regarding trapping activities at Lower Granite Dam in 1992). Our request to NMFS for inclusion of known hatchery fall chinook salmon in our radio tagged group was denied because of Endangered Species (ESA) concerns regarding hatchery fish escaping upstream of LGR Dam. Trapping occurred in conjunction with broodstock 
collection for Lyons Ferry Hatchery (Mendel et al. 1993b) . Salmon were trapped from 8 September until 4 December at LGR, but salmon were radio tagged from 14 september until 3 November. Some unclipped salmon were captured when random samples of fish were directed into the trap for scale sampling steelhead. We captured a few additional unclipped fall chinook salmon by watching the fish enter the chute near the metal detectors and then sending a false signal to the detector to open the gate into the trap.

Captured fall chinook salmon were netted out of the trap and anesthetized in a trough containing 220 L of water and MS 222 . They were measured (fork length), examined for marks, radio tagged, jaw tagged, coded-wire tagged, scale sampled, and released into the fish ladder upstream of the trap. Tagged salmon were able to recover in an isolated, quiet area in the ladder before continuing their migration upstream. A barrier prevented them from descending downstream in the ladder and returning to the tailrace of the dam. Transmitters implanted at LGR as well as other equipment, tagging, and data recording procedures were similar to those used at IHR.

\section{Radio Tracking}

Receivers were set to scan for coded transmitters (implanted at IHR or LGR) every six seconds to accommodate the 5 second signal interval, and to minimize total time taken to scan all channels. All transmitters implanted at IHR or LGR were on three channels in the receiver.

Salmon were radio tracked using several methods. Personnel from the ICFWRU had deployed numerous fixed-site receiver and instantaneous scanning digital signal processor (DSP) stations to monitor salmon and steelhead movements throughout the snake River drainage (Bjornn et al. 1992, Mendel et al. 1992). Fixed-site receivers were installed 0.5 to $2.0 \mathrm{~km}$ downstream of each of the four lower snake River dams, at various locations at each dam, and near the mouths of major tributaries. Each receiver monitored multiple yagi or underwater antennas to provide adequate coverage to detect migration of tagged fish past the dams and at river tributaries. In 1992, additional antennas monitored fishway entrances and the collection channel along the tailrace deck at all four snake River dams. Personnel from the ICFWRU graciously provided us with relocation data for fall chinook salmon obtained at their fixed-site receivers or during mobile tracking.

WDF personnel employed mobile radio tracking to relocate tagged fall chinook salmon. Pickup trucks were modified to accommodate the four element yagi antennas (manufactured by Cushcraft) needed to receive the 149 Mhz transmitter signals. Modified pickup trucks were used by both WDF and ICFWRU personnel 
for mobile radio tracking in areas away from the fixed-site receivers, or to supplement tracking from fixed-site receivers. Additionally, boats were occasionally used for mobile tracking. We closely coordinated our mobile tracking efforts with ICFWRU personnel to avoid duplication and data gaps.

Our primary means of tracking involved aerial surveys using a Cessna 172 fixed-wing aircraft in the larger river canyons. A Hiller helicopter was used in the narrow canyons to relocate radio tagged salmon. A four element antenna was attached parallel to the fuselage along the wing strut, pointing forward and down at a 30 degree angle, on the Cessna aircraft. The same four element yagi antenna, or a whip or "H" antenna, was attached to the leading edge of a landing support on the helicopter. The yagi antenna was oriented towards the front of the helicopter with the elements perpendicular to the river. Receiver gain had to be set between 60-80 to minimize engine interference in the receiver and allow the transmitter code to log on the receiver. Fixed-wing aircraft flew at altitudes of approximately $33-213 \mathrm{~m}$ and air speeds of 100-129 km/hr while tracking along the reservoirs.

Flights over reservoirs sometimes consisted of tracking while traveling upstream, about one third of the width of the river out from shore, and then tracking while going downstream near the other shoreline, to enable us to adequately cover the wide expanse of the reservoirs. Tracking by helicopter was limited to the narrow canyons and consisted of low level flights (8-150 $\mathrm{m}$ altitude) and air speeds of $8-80 \mathrm{~km} / \mathrm{hr}$. We conducted aerial radio tracking from Wanapum Dam (upstream of Priest Rapids Dam) to downstream of Irrigon Hatchery (below McNary Dam) along the mid Columbia River. We also surveyed from the mouth of the Yakima River to Wapato Dam (RR 171.5). Other areas surveyed included the following (from the river mouths): 1) the snake River to Hells Canyon Dam, 2) the Clearwater River to the south fork of the Clearwater River (RR 120.2), 3) the lower Grande Ronde River to Troy (RR 72.9), 4) the lower Salmon River to the town of Riggins (approximately RK 139), 5) the lower Imnaha River to above Cow Creek (Rk 6.1), 6) the lower Tucannon to Marengo Bridge (RK 39.9), 7) the Palouse River to Palouse Falls

(approximately RK 1l), and 8) occasionally along portions of the Walla Walla and Touchet rivers (for steelhead and salmon). We attempted to conduct aerial telemetry surveys of the snake and mid Columbia rivers at least every two weeks from 18 september until 23 December. However, poor weather forced cancellation or rescheduling of some of our flights. Weekly helicopter flights were conducted on the Snake River upstream of Asotin from 16 October until 12 December (except for the week of 20 November). 


\section{Recoveries}

We were able to recapture radio tagged salmon at LGR because metal in the radio or the coded-wire tag in the fish's back activated the trap gate. Recapture at the trap provided a valuable means to verify passage at the dam, to examine the condition of the fish, and determine presence or absence of the radio transmitter. Additionally, adult salmonids returning downstream were occasionally captured and examined at juvenile fish bypass separators at Little Goose Dam (LGO) and LGR by Corps of Engineers personnel.

We recaptured radio tagged salmon as voluntary returns at Lyons Ferry Hatchery on the Snake River (RK 95), or at Priest Rapids Fish Hatchery (RK 635.6) immediately below Priest Rapids Dam on the mid Columbia River. An additional salmon was recovered during broodstock collection by the Yakima Indian Nation at the Marion Drain Trap (RR 138.4) on the Yakima River. Personnel from WDF also searched for salmon carcasses with radio tags while conducting spawning surveys along the lower Tucannon and Palouse rivers (Mendel et al. 1993b), and along the Hanford Reach of the mid Columbia River. Additional recoveries came from WDF carcass recovery efforts above Lower Granite Reservoir

(Blankenship 1993) and in mid Columbia River sport fisheries.

\section{RESULTS and DISCUSSION}

\section{Salmon Tagged at Ice Harbor Dam}

\section{Tagging efforts}

Personnel from the ICFWRU assisted us by radio tagging fall chinook salmon at IHR. We attempted to radio tag fall chinook salmon throughout the duration of the run (Figure 2), but warm water temperatures limited our tagging efforts in early

September. Also, radio and spaghetti tagging of large numbers of steelhead by the ICFWRU personnel occasionally precluded our trapping and tagging of fall chinook salmon for the following reasons: 1) a lack of available personnel and equipment, or 2) disturbance in the fish ladder caused by removing steelhead for tagging kept salmon from entering the trap.

A total of 96 fall chinook salmon were radio tagged near IHR Dam in 1992 (Appendix B). This total includes 43 radio tagged salmon that were released at Charbonneau Park (CHAR), upstream of IHR and 53 fish released below IHR, at Hood Park (HPK). We alternated at different intervals between the two release locations to be as random as possible regarding release site used on a particular day. 


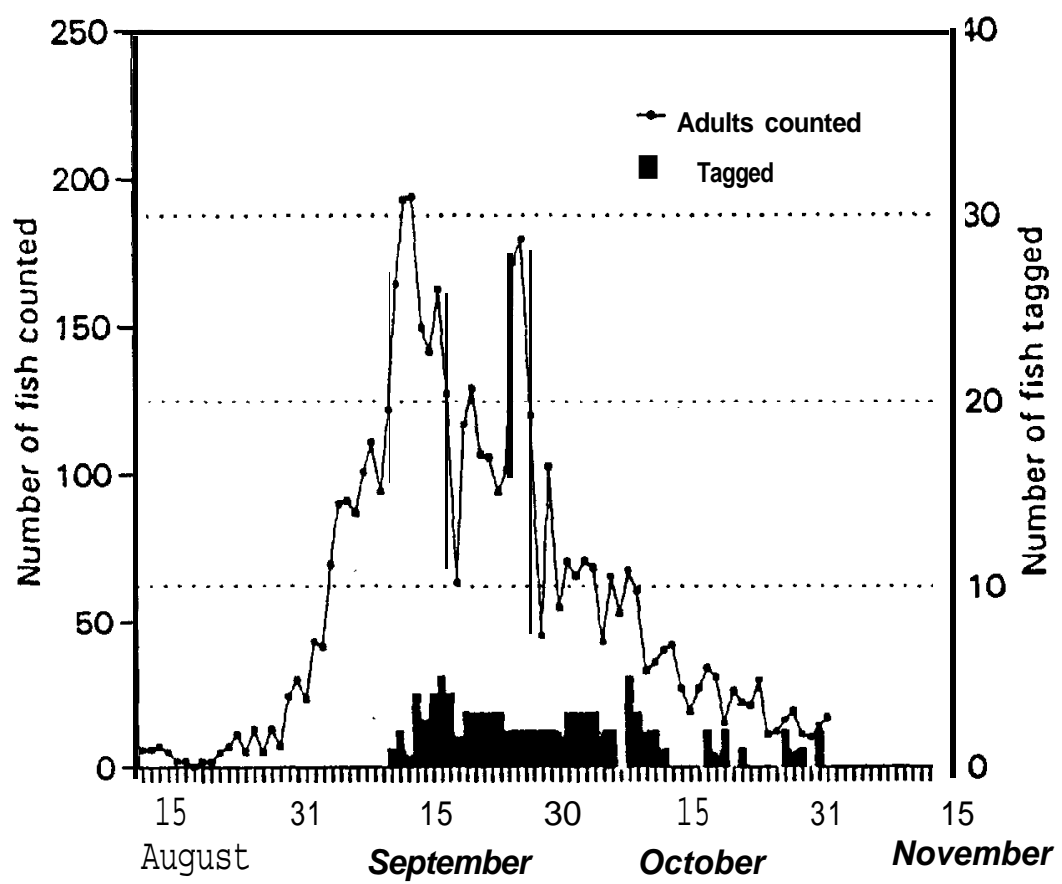

Figure 2. Fall chinook salmon run timing at Ice Harbor Dam with the distribution of salmon radio tagged, 1992 .

Tagging may have caused the mortality of one fish. This fish was recovered 13 days after tagging by an angler along the Columbia River, near Kennewick. External examination of the fish indicated it appeared to be in good condition, but it was not examined internally.

\section{Fish movements}

Initial movements of salmon after tagging were compiled into four categories: 1) no data, 2) upstream migration past the next dam, 3) upstream migration, but did not pass the next dam before moving downstream, and 4) immediate downstream movement after the fish was tagged and released (Appendix C).

Three ( 1 HPK and 2 CHAR fish) of the 96 radio tagged fish ( $3.1 \%)$ were never relocated after release. Therefore, we have relocation data for 93 fish (96.9\%; 52 HPK and 41 CHAR releases).

Of the radio tagged salmon we were able to relocate from our HPK release, 17 fish (32.7\%) apparently crossed IHR Dam immediately after release, or after some initial downstream movements (Appendices $\mathrm{C}$ and D). An additional $16 \mathrm{HPK}$ fish (30.8\%) initially moved upstream to IHR Dam (and possibly crossed, but could not be verified) then turned around and descended the Snake River. Two of these fish were last located below IHR Dam while the others descended to the Columbia River or its tributaries. The remaining 19 salmon released at HPK initially returned to the Columbia River after release. Only two of these fish are known to have reascended the snake River (as far upstream as IHR Dam). 
Thirteen (31.7\%) of the fish released at CHAR moved downstream over IHR (fell back) soon after release. Four of these fish recrossed IHR Dam, but only three of them remained upstream of the dam and crossed the next dam upstream (Lower Monumental Dam - LMO Dam). Another five (12.2\%) fish released at CHAR moved upstream towards LMO Dam, but they fell back at IHR Dam without having crossed LMO. One of these five fish later returned from the Columbia River and recrossed IHR. It moved upriver as far as the Tucannon River before descending to LMO Dam, where it was lost. Therefore, 18 salmon initially fell back at IHR before crossing LMO Dam, but four of these fish reascended IHR and crossed LMO Dam (14 net fall backs). An additional 22 (53.7\%) of the tagged fish released at CHAR initially moved upstream and crossed LMO.

A total of 42 radio tagged salmon are known to have crossed LMO Dam (16 from HPK and 26 from CHAR - Fig. 3). Ten of the fish upstream of LMO entered and spawned at Lyons Ferry Hatchery (LFH) // while another three fish were last located near there. Three fish fell back at LMO Dam and descended below IHR Dam (Figure 4). Two fish apparently spawned in the Tucannon River (Figure 5). Another four fish were last located in the reservoir. One of these fish was actually last located at the top of the ladder at Little Goose Dam (LGO Dam), but we can't confirm that it crossed the dam.

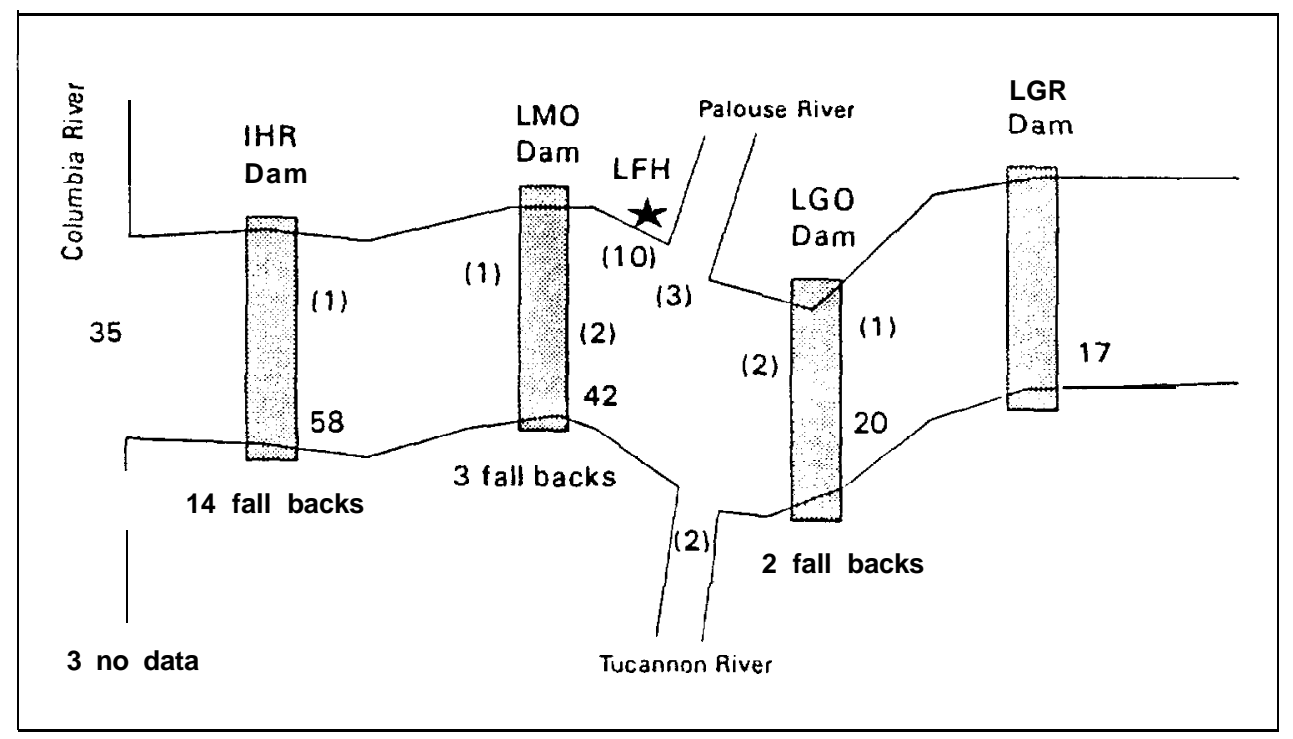

Figure 3. Numbers of radio tagged fall chinook salmon (from 96 fish released near IHR Dam) at various points in the Snake and Columbia River, 1992. Numbers in parentheses are fish that were "lost" in the reservoir or entered Lyons Ferry Hatchery (10 fish), without crossing the next dam upstream (For example, 58 fish crossed IHR Dam, 14 fish fell back and two were lost, so 42 fish crossed LMO Dam). 


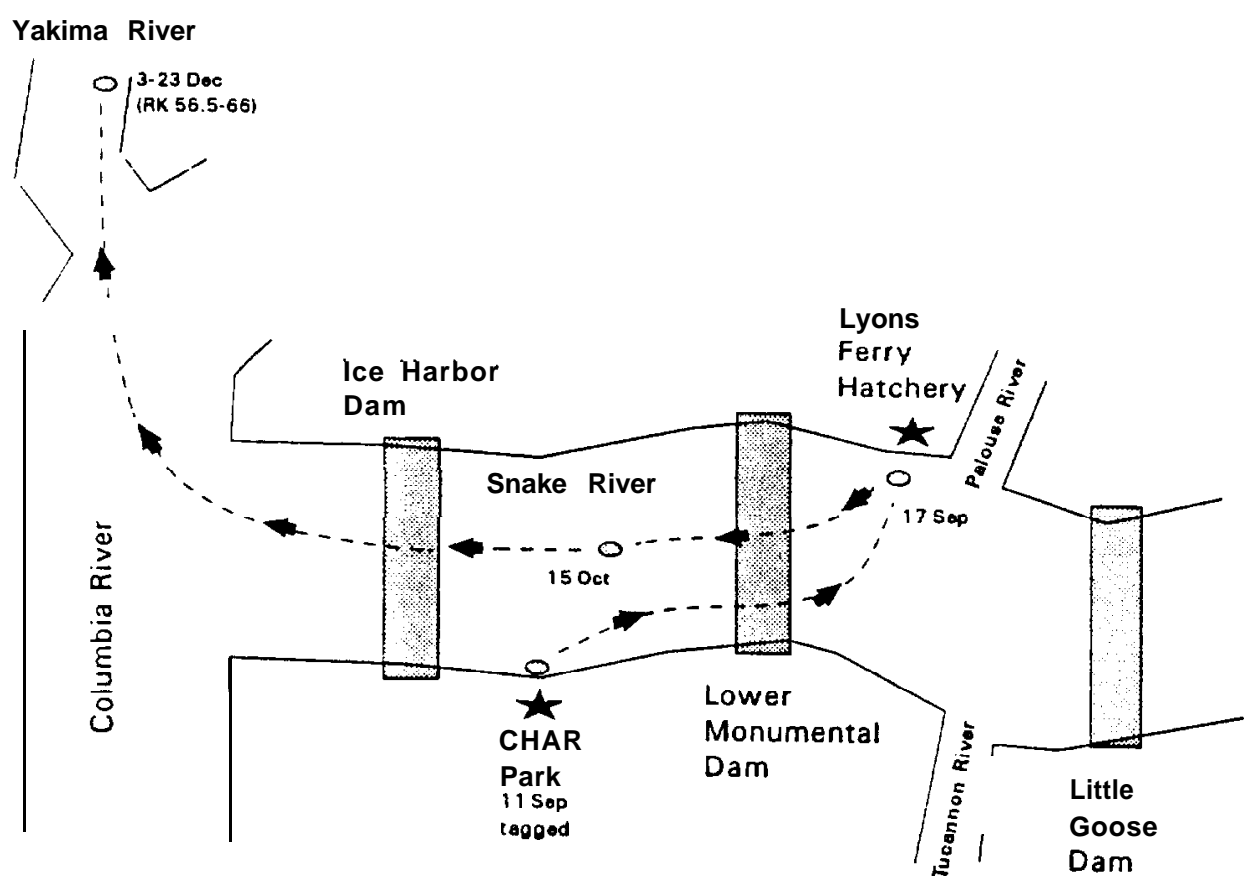

Figure 4. An example of a radio tagged salmon (chan.1/45) that fell back after crossing LMO Dam to the Columbia River, 1992.

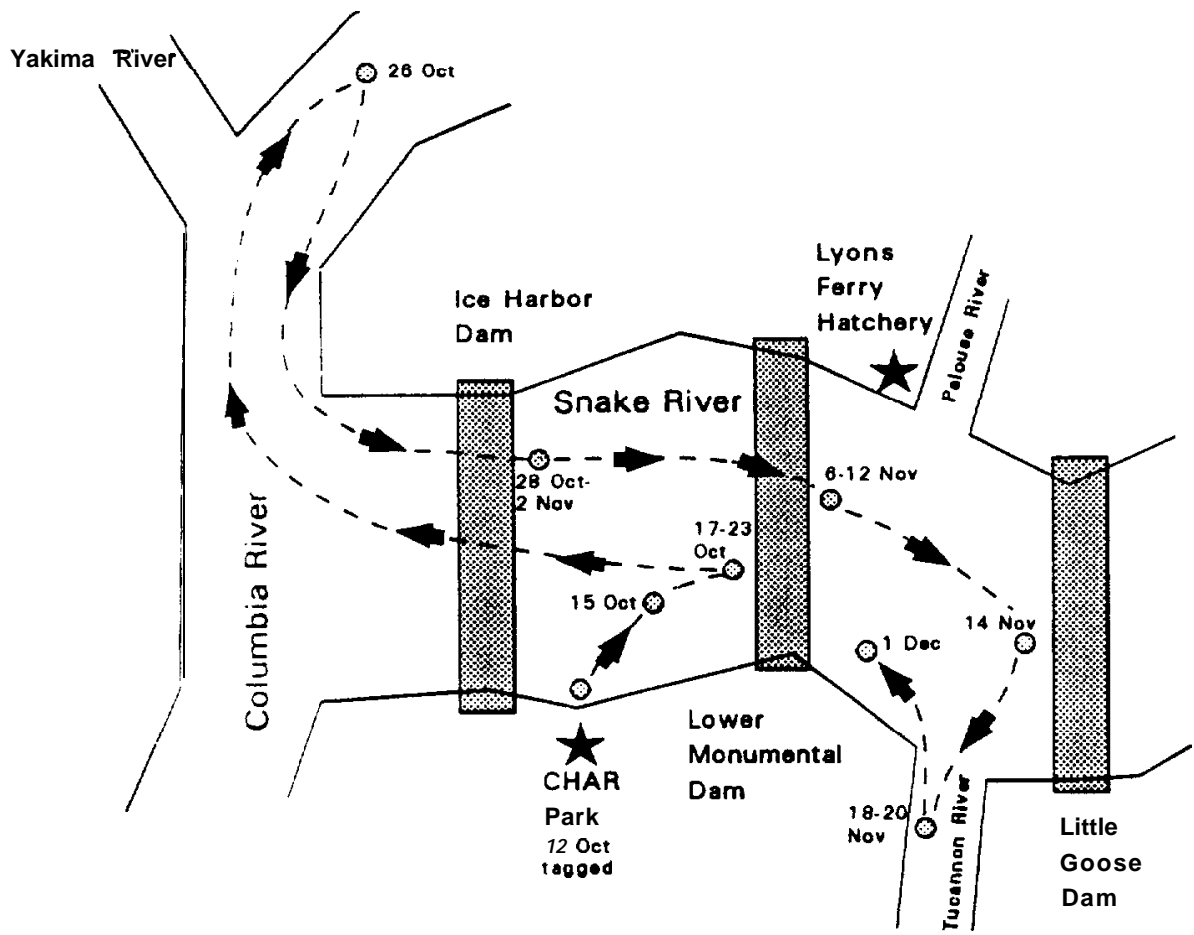

Figure 5. Movements of one of the radio tagged fall chinook salmon (chan. 2/4) that apparently spawned in the Tucannon River, 1992 . 
We have evidence that some additional fish may have crossed IHR Dam (HPK fish) or LMO Dam (CHAR fish). However, we cannot confirm their passage and fall back because of gaps in the data at the dams caused by long receiver scan times. Other detection problems occurred as well. For example, radio signals were not detected by fixed-site receivers at LMO Dam for 25 of 42 salmon (59.5\%) known to have crossed that dam.

Twenty radio tagged fall chinook salmon are known to have crossed LGO Dam. TwO fish fell back at LGO. One of these fish travelled upstream to the base of LGR, returned downriver (fell back at LGO Dam) to near Lyons Ferry $F H$, returned upstream to the base of LGR, and then fell back to below LMo Dam (Figure 6). The other fish travelled upstream as far as the base of LGR and then fell back to near Lyons Ferry FH. Another fish was last located in LGO reservoir.

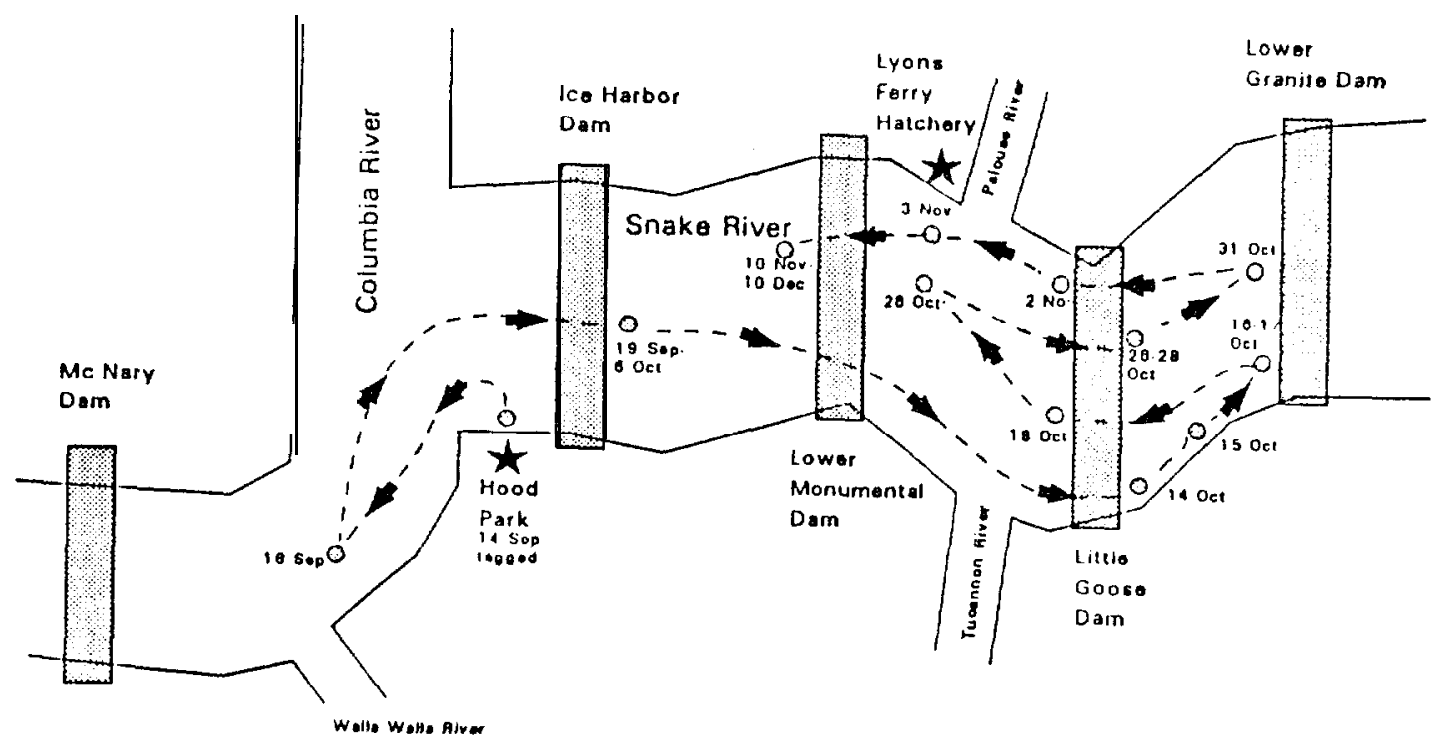

Figure 6. Movements of a radio tagged fall chinook salmon (chan. 2/45) that fell back twice at LGO Dam, 1992.

A total of 17 ( 6 HPK, 11 CHAR) tagged fall chinook salmon from IHR crossed LGR Dam. Seven (41.2\%) of these fish fell back at LGR. Three of these fish (1 HPK, 2 CHAR) fell back and entered Lyons Ferry Hatchery (Figure 7) and two other fish (HPK) fell back over LGR Dam several times. One of these fish fell back at LGR 3 times (chan. 1/46). Another fish (CHAR) regurgitated its tag in the adult trap at LGR. One fish released at CHAR fell back to the Columbia River where it was caught prior to spawning in the sport fishery in the McNary Dam forebay (Figure 8). Another CHAR fish fell back to LMO Dam forebay. Nine fish tagged at IHR Dam ( 3 HPK, 6 CHAR) remained above LGR Dam and apparently spawned in 1992 . 


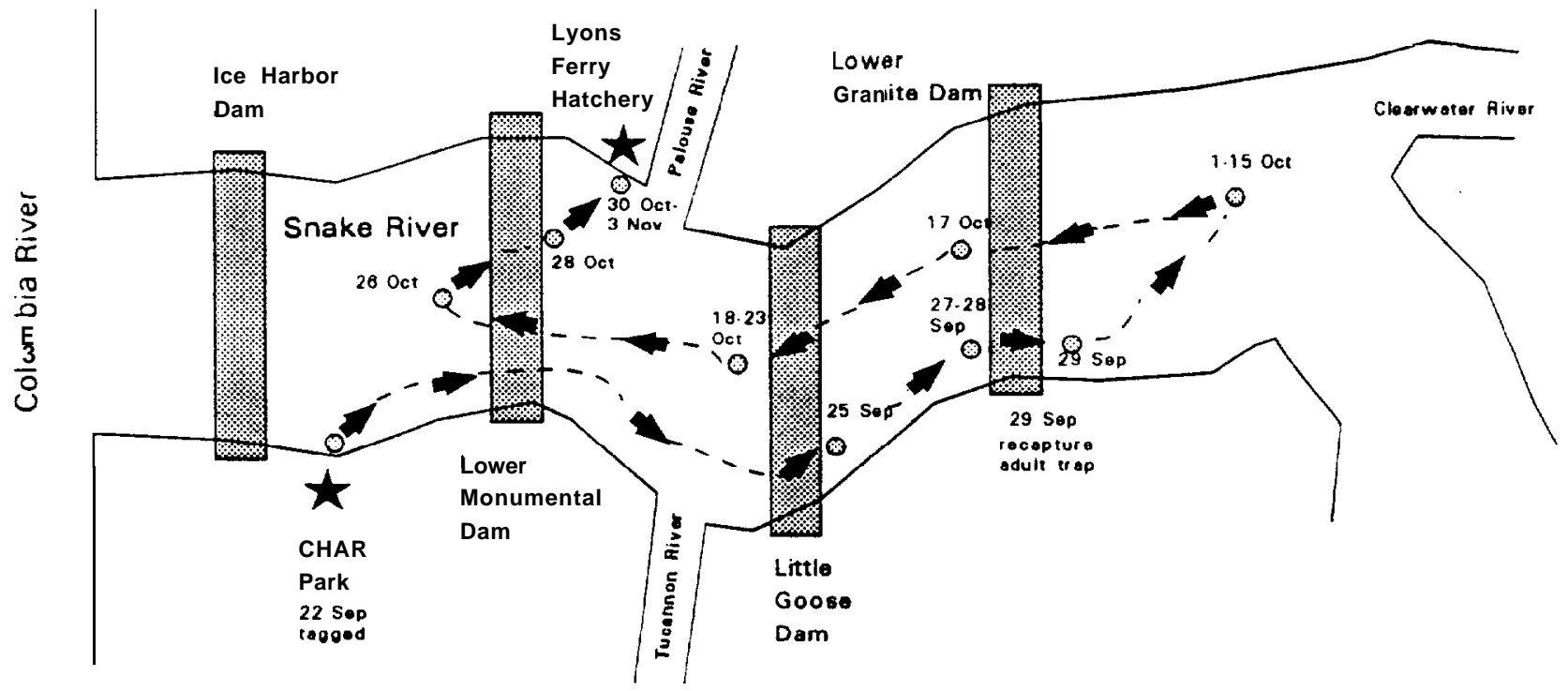

Figure 7. Movements of a radio tagged fall chinook salmon (chan. 3/20) tagged and released near IHR Dam that crossed LGR Dam before falling back and entering Lyons Ferry Hatchery, 1992.

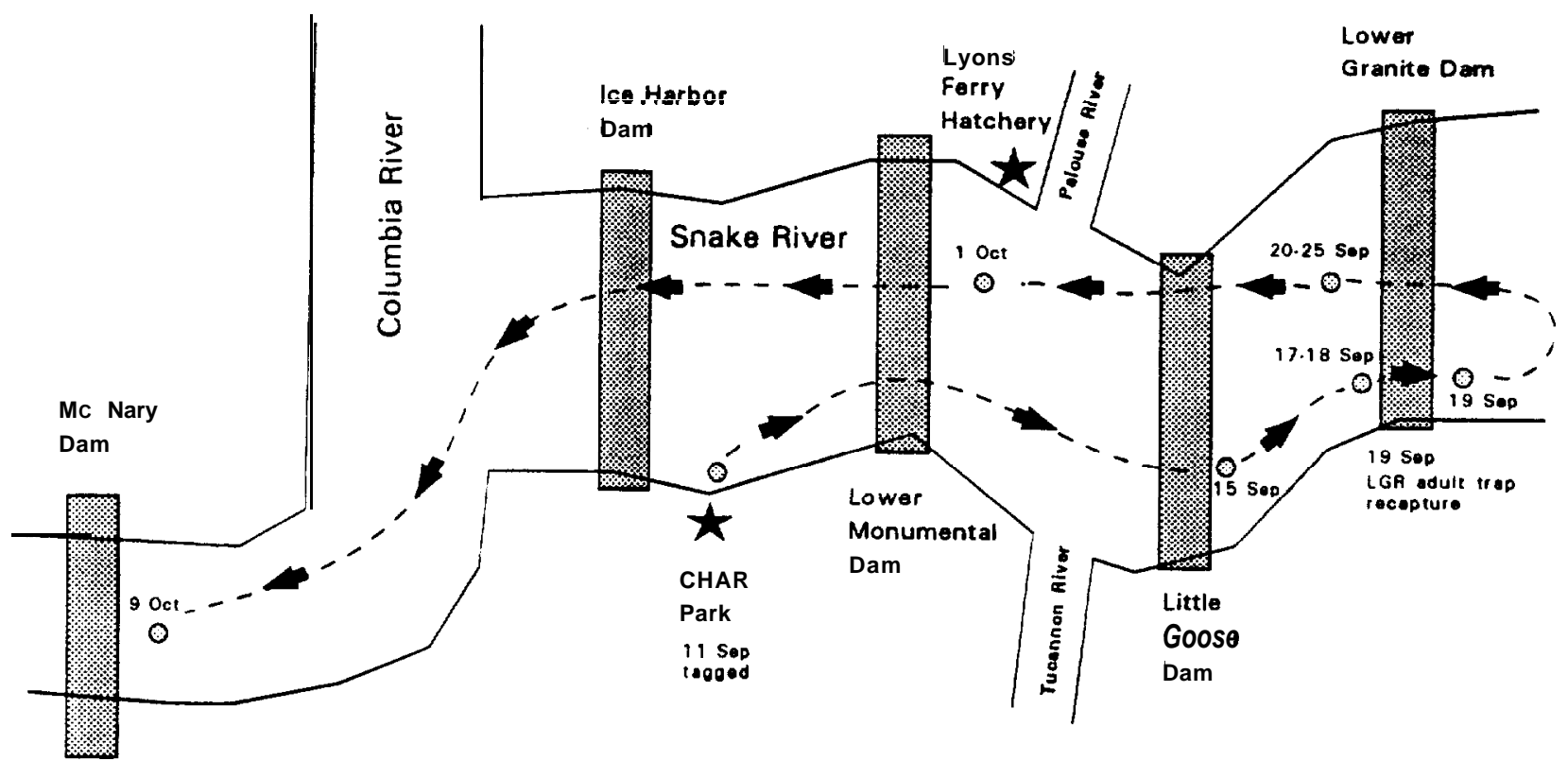

Figure 8. Movements of a radio tagged fall chinook salmon (chan. 1/28) tagged and released near IHR Dam passed upstream of LGR Dam before falling back at all four lower snake River dams. It was recovered in the sport catch in the forebay of McNary Dam on 9 October, 1992. 
Our results show some interesting migration behaviors by fall chinook salmon in 1992. The most obvious observation is that approximately 50\% (46 of 93) of the salmon that we were able to radio track were last found outside the Snake River drainage, primarily in the Columbia and Yakima rivers. Twenty-four salmon

(17 HPK, 7 CHAR) were last located in the Columbia River (mostly in the Hanford Reach) and another 22 fish (15 HPK, 7 CHAR) were found in the Yakima River (see Appendices C and D for tracking summaries). Of the 52 trackable fish released at HPK, about 62\% were last located outside the Snake River drainage, as were 34\% of the 41 trackable fish released at CHAR.

We documented that tagged salmon did not cross lower snake River dams at the same rates. As in 1991, many salmon remained near IHR Dam for long periods of time, and in some cases they moved to the Columbia River before returning to the dam. The average amount of time for salmon to pass IHR Dam was 10.4 days $(\mathrm{SD}=9.8$, range=1-38 days, $\mathrm{n}=18 \mathrm{fish})$ in 1992. Average passage durations at other lower snake River dams were 2.3 days at LMO $\operatorname{Dam}(\mathrm{SD}=2.0$, range $=1-7, \mathrm{n}=17), 3.2$ days at LGO Dam $(\mathrm{SD}=5.4$, range $=1-19, \mathrm{n}=20)$, and 2.7 days at LGR Dam $(S D=2.0$, range $=1-8$, $\mathrm{n}=17$ ). These results are similar to our observations in 1991, except at LGR Dam where passage times were much faster in 1992 . We used the difference between the first and last dates each fish was received by any antenna at a dam (uninterrupted by relocations elsewhere, or fall back), to determine passage times. We made no attempt to determine actual elapsed time (hrs or minutes) from the downstream receiver to the upstream receiver, or antenna at the exit of the ladder, as a measure of passage time (as was calculated by the ICFWRU for spring/summer chinook salmon and steelhead) for the following reasons: 1) some fish were not received at all antennas, 2) we could not always determine actual ladder exit time, and 3) some fish remained near the upper or lower portion of the dam for extended periods. We believe that the full duration of time a fish spent at a particular dam may be a better comparative measure of fish passage at lower Snake River dams than elapsed time from the downstream antenna to the top of the ladder. We may further examine dam passage duration by fall chinook salmon in subsequent reports.

We did not attempt to document migration rates through the lower Snake River, but we did note that fixed-site receivers often documented movements of fish from one dam to another in less than one day. We are unsure these data are complete enough to determine actual migration rates, and our sample size is relatively small.

As was noted in 1991 (Mendel et al. 1992) many fish appeared to wander back and forth between dams, or to fall back at dams in 1992. Few tagged salmon appeared to migrate directly upstream to their spawning location without at least some downstream 
movements. Some fish appeared to move directly to the Columbia River (Figure 9) while others wandered back and forth between the Columbia River and IHR Dam (Figure 10). Other tagged salmon travelled upstream into the free flowing portion of the Snake River before returning downstream through several dams (Figures 4 and 8 ).

Radio telemetry has enabled us to examine the behavior of salmon that eventually entered Lyons Ferry Hatchery (LFH). As in 1991, over 80\% (10 of 12: 2 HPK, 8 CHAR) of the radio tagged salmon recovered at LFH in 1992 (after release from IHR Dam) had gone as far upstream as LGO Dam before they entered the hatchery (includes 2 CHAR fish that crossed LGR Dam before entering LFH. Note : five salmon radio tagged at LGR also returned to LFH). Many fish moved back and forth between LMO Dam, LFH and LGO Dam several times before entering the hatchery. These movements are similar to observations we made in 1991 (Mendel et al. 1992). In 1992, a radio tagged salmon (HPK) went up the Columbia River into the Hanford Reach before returning to the Snake River and into LFH (chan. 2/6). Radio tagged salmon entering LFH did not contain coded-wire tags so we are unable to determine their origin.

\section{$\underline{\text { Fall back }}$}

Fall back of radio tagged fall chinook salmon was documented at all lower snake River dams each of the last two years (Table 1). Eighteen tagged salmon (CHAR) fell back at IHR Dam in 1992 prior to crossing LMO Dam. Twenty-three fall back events occurred at IHR Dam during the fall season by twenty-two individual fall chinook salmon. We documented fall back at LMO Dam ( 6 fall backs: 1 HPK, 5 CHAR), LGO Dam ( 8 fall backs by 7 salmon: 3 HPK, 4 CHAR), and LGR Dam (9 fall backs by 7 salmon: 3 HPK, 4 CHAR) by a total of 12 different fish. Some individual fish fell back multiple times at lower snake River dams in 1992. One fish (CHAR, chan. 3/15) fell back twice at IHR Dam. Another fish (HPK, chan 2/45) fell back twice at LGO Dam (figure 6), and another salmon fell back three times at LGR Dam (HPK, chan. 1/46). A total of seven tagged salmon from IHR fell back at LGR Dam: two fish (HPK) were last located below LGR Dam, four other fish ( 1 HPK, 3 CHAR) also fell back at LGO Dam and either entered LFH ( 1 HPK and 1 CHAR) or were last located in LMO reservoir, and one fish (CHAR) fell back over all four of the lower snake River dams. This fish was recovered in the Columbia $\mathrm{R}$. sport fishery in the McNary Dam forebay (Figure 8). Overall, we documented 46 total fall backs past snake River dams by 30 different fish from the HPK and CHAR releases. 


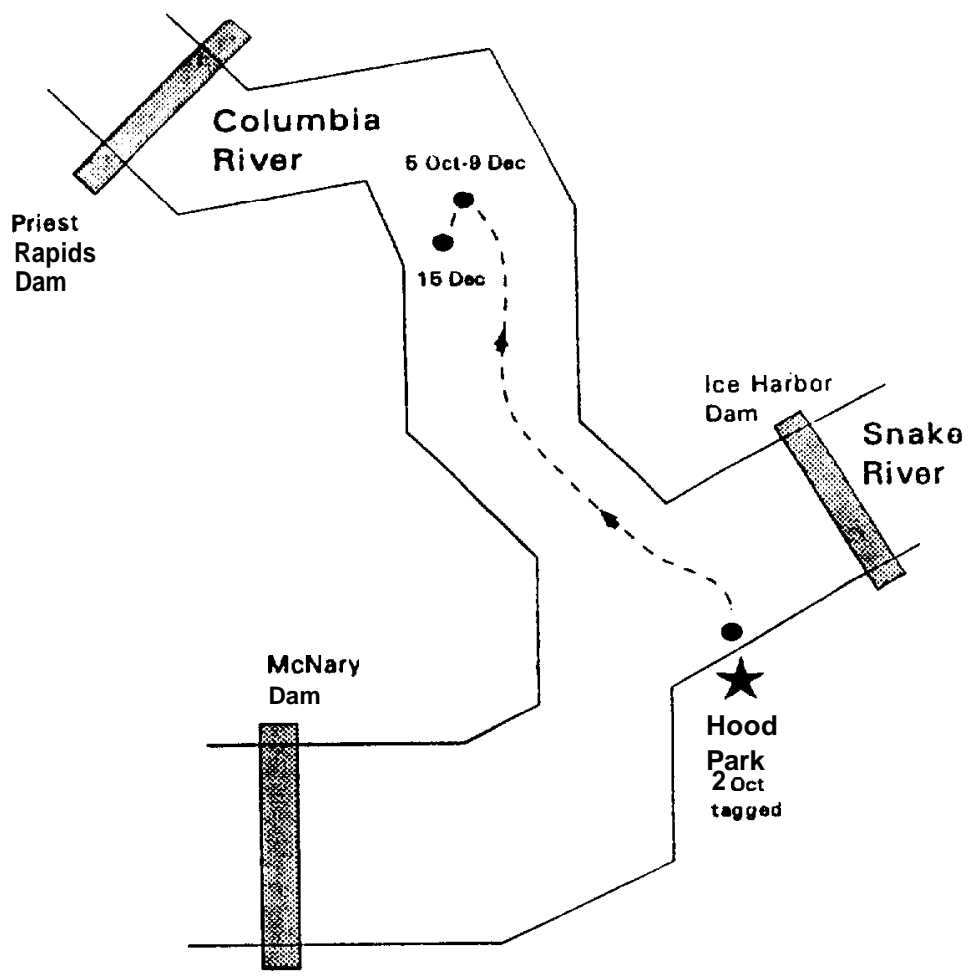

Figure 9. Movements of a radio tagged fall chinook salmon (chan. 2/32) that apparently did not attempt to cross IHR Dam after release, 1992 .

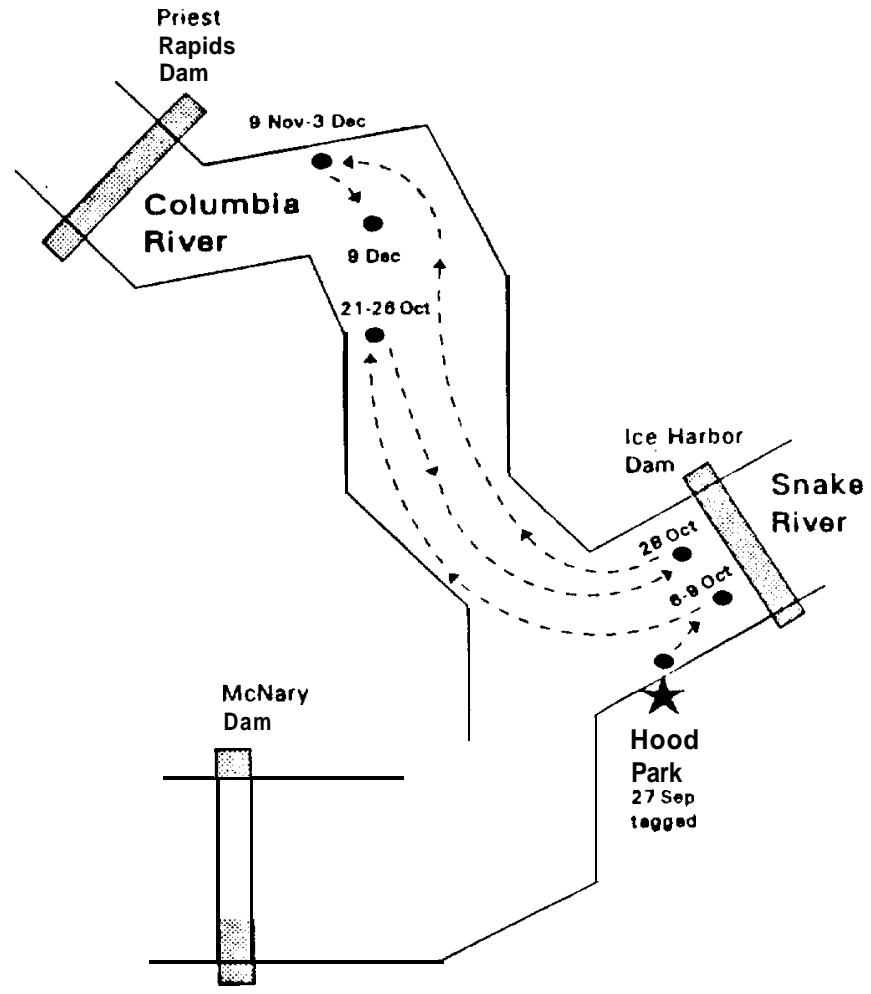

Figure 10. Movements of a radio tagged fall chinook salmon (chan. 1/22) that demonstrates some of the wandering movements observed between the Columbia River and IHR Dam, 1992. 
Fall back has been documented for large numbers of adult and jack fall chinook salmon and steelhead at juvenile bypass facilities at McNary Dam (Wagner 1991, Wagner and Hillson 1992), Little Goose Dam, and Lower Granite Dam (unpublished data from Corps of Engineers and ICFWRU) in recent years. In 1992 for example, 79 adult fall chinook salmon (8.9\%) were observed falling back through the juvenile bypass facility at LGR Dam from a total of 885 adults salmon counted as they migrated upstream past the dam (Unpublished data from the Corps of Engineers, Teri Barila). A few of our radio tagged salmon were observed falling back through juvenile bypass facilities at LGO or LGR dams during the past two years. Documentation that fall back is relatively common for unmarked fall chinook salmon at juvenile bypass facilities tends to support our belief that movements of radio tagged salmon reflect movements of unmarked fish.

Interdam losses

We attempted to account for all radio tagged fall chinook salmon (96 total) between IHR Dam and LGR Dam to determine the cause of disparities between salmon counts at these dams in previous years. Ninety-three of the 96 salmon radio tagged near IHR Dam were relocated in 1992. Fifty-eight of the tagged fish recrossed the dam, or remained upstream of IHR Dam, after release. Ten of these tagged salmon were recovered at Lyons Ferry Hatchery. Another two fish were found in the lower Tucannon River. Seventeen additional radio tagged salmon crossed LGR Dam (reached the adult trap). Therefore, 29 of 58 (50\%) tagged salmon known to be upstream of IHR Dam could be accounted for by applying the standard accounting method we use for unmarked fish. To simplify the procedure we did not count fish twice if they fell back at IHR and then moved upstream and recrossed the dam. We documented that 18 of 29 (62.1\%) tagged salmon that we did not account for with the standard accounting procedure fell back at IHR Dam before reaching LGR Dam. The remaining 11 radio tagged fish were last located within the reservoirs.

We applied this same accounting procedure to the total fall chinook salmon (adults and jacks) counted at $\operatorname{IHR} \operatorname{Dam}(5,530)$ in 1992 (Corps of Engineers 1993). We summed returns to Lyons Ferry Hatchery $(1,401)$, estimates of spawning escapement in the Tucannon (69) and palouse (2) rivers, as well as fish reaching LGR Dam (957), for a total of 2,429 fish (Mendel et al. 1993b). Consequently, we were unable to account for 3,101 salmon (56\%) after they passed IHR Dam in 1992. Upon further examination of the fall chinook salmon dam counts we found that only 45\% $(2,493)$ of the fish counted at IHR Dam were counted at LMO Dam in 1992. Therefore, most of the loss we have documented between IHR and LGR appears to occur before the fish reach LMO Dam. This statistic tends to support the results from our radio telemetry 
study and suggests that the high fall back rate at IHR Dam in 1992 accounts for the majority of total losses between IHR and LGR dams.

Salmon Tagged at Lower Granite Dam

Tagging efforts

Personnel from NMFS and WDF were able to implant radio transmitters into $20 \mathrm{fall}$ chinook salmon at Lower Granite Dam (Appendix E) from 14 September to 3 November. A branded (RD-U-1) hatchery salmon was inadvertently radio tagged and released at LGR Dam.

\section{Fish Movements}

All 20 salmon radio tagged at the adult trap are assumed to have crossed the dam after being released into the ladder. We were able to relocate 19 of the 20 tagged salmon upstream of LGR Dam, plus one tagged fish that was last located at the top of the fish ladder.

Six (31.6\%) of the tracked fish apparently fell back at LGR Dam (avg. 23.3 days, range 7-38 days after tagging). One of those fish fell back twice and remained below LGR Dam (Figure 11), but four others descended to Lyons Ferry Hatchery (fell back over two dams). All four of these fish were spawned at LFH as unmarked fish (includes a branded hatchery salmon from spring Creek Hatchery used in the Bonneville Bypass Study). One fish fell back (over two dams) to the Tucannon River.

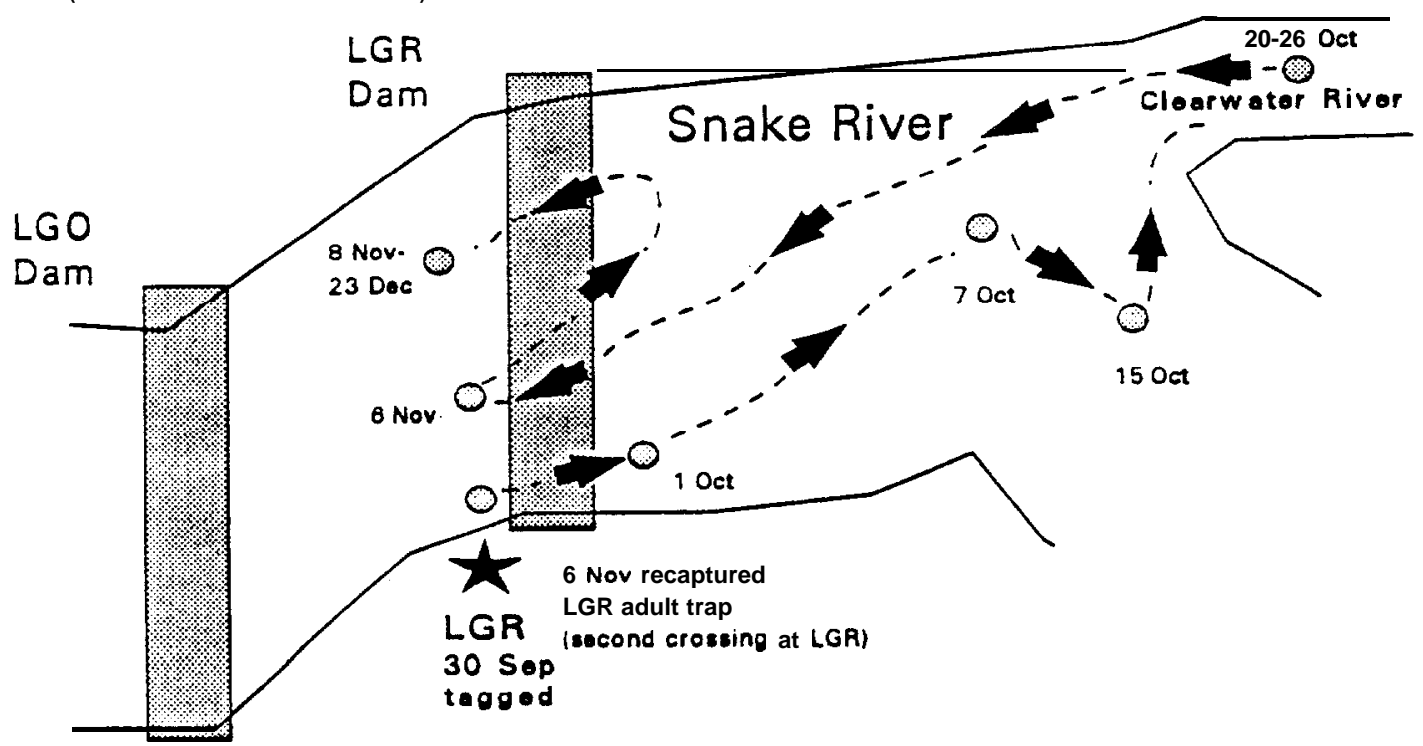

Figure 11. Movements of a radio tagged fall chinook salmon (chan. 1/30) released at LGR Dam that fell back twice at LGR Dam and remained in the tailrace, 1992. 
Fourteen fish radio tagged at LGR Dam remained above that dam throughout the tracking season (including one fish that was last detected at the top of the fish ladder). One salmon was last located within LGR reservoir, and eight salmon were relocated within the Clearwater River (Note: One of these fish died and was recovered on the Clearwater River 22 days after tagging. We do not know the cause of death). Three other fish apparently spawned (two in the middle Snake River upstream of Asotin and below the Grande Ronde River and one in the lower Grande Ronde River). One other tagged salmon was found near a rapid in the lower Salmon River.

\section{Radio Tagged Salmon from all Release Sites}

\section{Interdam Losses Upstream of LGR Dam}

We combined radio tagged salmon from IHR and LGR dams to assess interdam losses and to identify spawning locations upstream of LGR Dam (Figure 12). That provided us with a sample of 17 fish tagged at IHR (11 CHAR, 6 HPK) and 20 from tagging at LGR Dam. One fish each from IHR and LGR dams were last known to be at the adult trap (regurgitated transmitter), or at the top of the fish ladder.

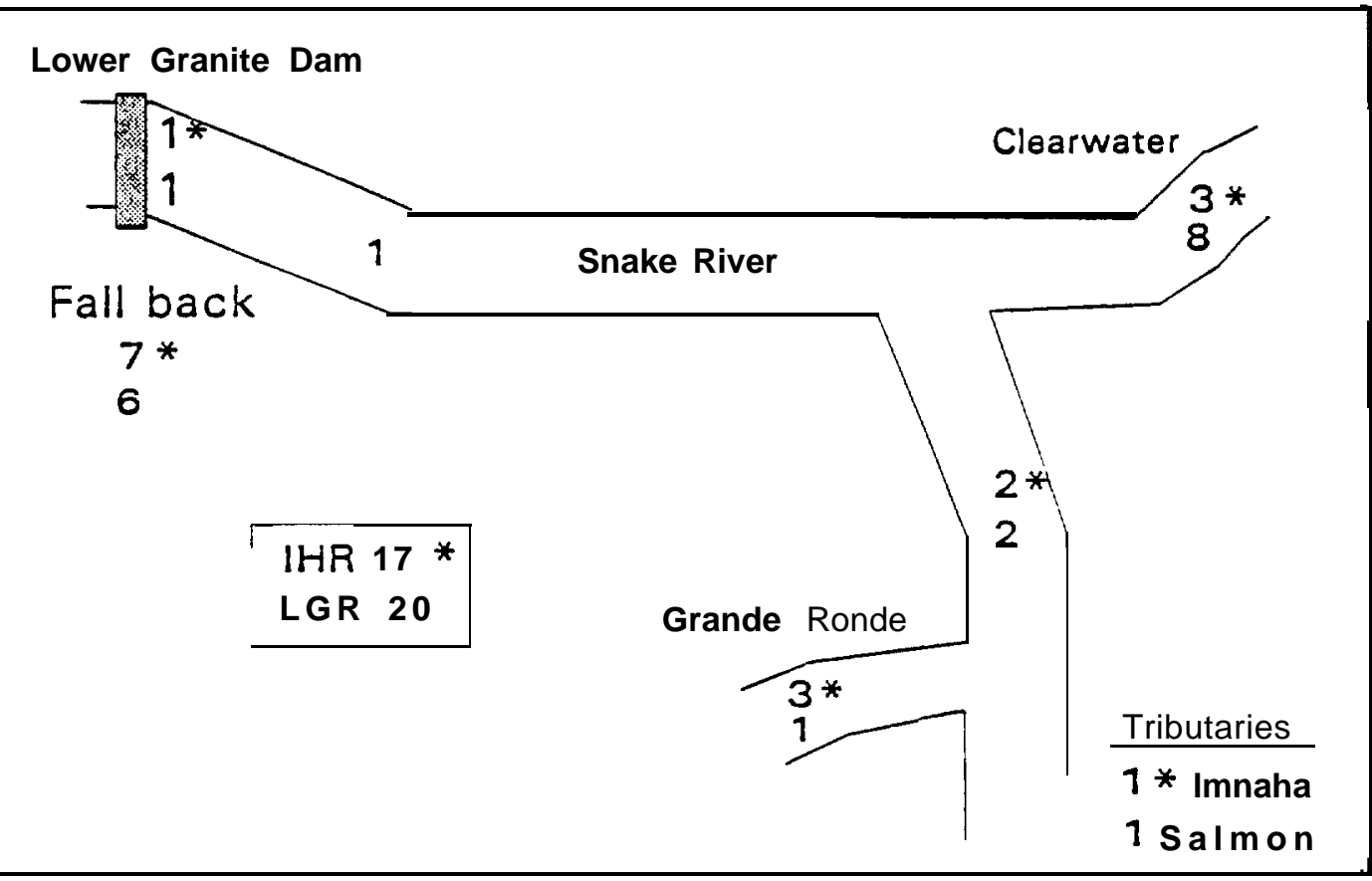

Figure 12. Apparent distribution of radio tagged fall chinook salmon upstream of LGR Dam in 1992. Seventeen salmon were tagged at IHR (numbers followed by asterisk) and 20 were tagged at LGR. All fish in the Snake (upstream of the Clearwater River), Grande Ronde, and Clearwater rivers apparently spawned, except two fish (one in the Clearwater, and one in the lower salmon River). 
Six tagged salmon from LGR and seven (3 HPK, 4 CHAR) from IHR fell back at LGR Dam. Therefore, we estimate a minimum fall back rate of 35.1\% for the total tagged fall chinook salmon (37) known to have crossed LGR Dam in 1992. The fall back rate at LGR Dam for salmon tagged at IHR Dam was $41.2 \%$ (7 of 17), which was higher than the $30.0 \%$ fall back rate for salmon tagged and released at LGR Dam ( 6 of 20). The combined fall back rate is 37.1\%. These estimates of fall back do not include multiple fall backs at LGR by individual fish, or two fish that were last located in the fish ladder at LGR. They do include one fish (or transmitter) that may have been flushed out of the ladder to below the dam, instead of falling back.

One tagged fish was last located in the reservoir and another salmon died in the clearwater River. We believe that the fish (Chan. 2/36) found dead in the Clearwater River was a prespawning mortality because it was recovered in early october, prior to the spawning season. If these two fish are included with the two tagged salmon last found in the LGR ladder, we conclude that $10.8 \%$ of the fish were "lost" or prespawning mortalities. A tagged salmon (chan. 3/10) in the lower Salmon River (RK 4.8) may also fit within this category, therefore, the loss may be as high as $13.5 \%$.

\section{Spawning}

We detected radio tagged salmon that apparently spawned upstream of LGR in the following areas: 1) the Snake River downstream of the Grande Ronde River (four fish), the Clearwater River near Cherrylane Bridge (10 fish), the Grande Ronde River (four fish) below the "Narrows" (RK 7), and the lower Imnaha River (one fish). Aerial spawning surveys confirmed the presence of redds in these areas. We believe that aerial surveys would not have missed these redds even without radio telemetry. However, radio telemetry enabled us to locate some fish in unexpected locations. We located a radio tagged salmon while on a spawning survey flight of the Snake River that may have been on a redd ( $\mathrm{kk}$ 259). This possible redd was observed from the air, but it undoubtedly would not have been seen without the radio detection at that location. This possible redd was not located by "ground" surveys conducted by the USFWS or IPC. Consequently, it could not be confirmed as a redd. The fish and redd appeared to be in relatively fast water near the lower end of a gravel bar. Another tagged fish was relocated during spawning season in an area that did not appear suitable for spawning. This fish was found in a location that appeared to contain large rock substrate near the tailout of a pool, below a rapid in the lower salmon River. We could not confirm that the fish was alive and active at that location. One other tagged fish was relocated outside of known spawning areas. An angler found the tags and carcass of a fall chinook salmon approximately $1.6 \mathrm{~km}$ upstream of the town of 
Troy on the Grande Ronde River. We had last detected this fish in the lower Grande Ronde on 30 October. We were notified of the recovered tags and carcass several months later.

Radio tagged salmon carcasses were recovered from spawning areas in the Imnaha and Clearwater rivers (Blankenship 1993, Bill Arnsberg, NPT, unpublished data).

The adult-per-redd ratio upstream of LGR Dam in 1992 was 8.2 (Mendel et al. 1993b). However, when we reduce the adjusted count of adult fall chinook salmon over LGR Dam (855) to account for broodstock collected for Lyons Ferry Hatchery, we obtain an estimate of 668 adult (and 80 jack) salmon that escaped to spawn upstream of LGR. If we again reduce that number by 35\% to account for fall back, and $10.8 \%$ for "lost" fish or prespawning mortalities, we estimate that 387 adult salmon may have spawned upstream of LGR Dam. By dividing that number by the number of redds (83) observed upstream of LGR, we find that the adult-perredd ratio is reduced to 4.7 .

With radio telemetry we attempted to determine whether spawning was occurring immediately downstream of the four lower Snake River Dams. It has been commonly believed that if spawning was occurring downstream of LGR that it most likely would occur in the tailrace areas downstream of the dams where the river has higher velocities. We noticed that many of our radio tagged salmon spent a few days to a few weeks in tailrace areas (within 2 miles downstream of a dam) in the lower snake River. However, subsequent movements of these fish was either into the hatchery or upstream into typical spawning areas. Thus, we have no strong evidence that any radio tagged salmon spawned in the lower snake River downstream of LGR Dam.

Fall back bv radio tagged salmon

Fall chinook salmon radio tagged at both IHR and LGR commonly fell back at lower snake River Dams in 1992 (Table 1). The fall back rate of 63.2\% for salmon tagged at LGR (12 of 19 fish) was higher than the $51.7 \%$ observed for those fish tagged at IHR (30 of $58 \mathrm{fish}$ ). Most fall back events (86.2\%: 50 of 58) occurred prior to 1 November and the peak of spawning season in mid-November. Therefore, we believe that most of the fall backs occurred prior to these fish spawning. We observed that some fish that fell back at dams entered LFH and spawned there. others apparently spawned and died in the Yakima River, or the Hanford Reach of the Columbia River, after fall back. Only 13.8\% ( 8 of 58) of the fall backs at dams occurred after the end of October, and most of these fall backs were at the upper two dams. Consequently, we have little evidence that the observed fall backs were occurring after salmon had spawned. 
Radio tagged salmon in 1992 apparently survived fall back at dams at a rate of $86.2 \%$ (50 of 58 total fall backs; and $94 \%$ survival of fallbacks prior to 1 November). This estimate of survival should be used as a minimum estimate based only on subsequent movements or recapture of those fish after fall back. Radio tagged salmon may have survived additional fall backs but we do not have enough evidence to determine the fate of these fish.

Unfortunately, we were unable to positively determine the routes of descent used by fall chinook salmon as they fell back at Snake River dams. We did not, however, document salmon descending the fish ladders past fixed-site receivers and antennae, so we do not believe that route was used. Also, water was not being spilled at any of the four dams from 1 september through December, except on 12 November at LGO (3.3 kcfs - Corps of Engineers, 1993). A few salmon may have returned downriver through the navigation locks, but we believe that most fall backs occurred through the turbine intakes. Tagged salmon or radio transmitters have been observed or recovered after being deflected into juvenile bypass facilities at LGR and LGO during the past two years. Also, both radio tagged and unmarked salmon have been documented falling back through these dams in 1991 and 1992 (unpublished data from Corps of Engineers and ICFWRU).

These observations tend to support the conclusion that most fall chinook salmon fall back through the turbine intake. Salmon are then either deflected into the juvenile bypass system or they move directly past the turbine blades.

\section{Loss of Tags}

We wished to determine if our relocations, recaptures, and recoveries were presenting an accurate picture of what was happening to radio tagged fall chinook salmon. Lost tags or malfunctioning transmitters may cause us to categorize fish as " lost" in a reservoir because that was the last detected location, or as "no data" because we were unable to relocate that fish. Therefore, we summed all recoveries (31 fish: 11 HPK, 13 CHAR, 7 LGR) of fish, jaw tags, and transmitters with the recaptures of fish at the LGR trap to evaluate the rates of jaw tag loss, regurgitation of transmitters, and transmitter failure. We obtained recovery information from several locations: 1) Priest Rapids Hatchery, 2) Marion Drain (broodstock collection Yakima River), 3) spawning survey recoveries in the Hanford Reach of the Columbia River, Imnaha River, and Clearwater River, 4) LGR trap, and 5) Lyons Ferry Hatchery. Jaw tag loss was $12.2 \%$ ( 6 of 49) and transmitter loss was $6.2 \%$ ( 3 of 48 ). Two of the transmitters were recovered from the adult trap at LGR or the juvenile bypass facility at LGO Dam. All transmitters were functioning when recovered. 
Table 1. Summary of fall back events at lower snake River dams by radio tagged fall chinook salmon, 1992. Data are presented to indicate those fall backs that occurred prior to the date spawning is likely to have occurred (prior to 1 November; early spawning season). We are uncertain whether fish falling back at a dam after 31 October spawned prior to falling back.

\begin{tabular}{|c|c|c|c|c|}
\hline & IHR & LMO & LGO & LGR \\
\hline Total number of fall backs & 23 & 6 & 13 & 16 \\
\hline (number of $\mathrm{fish})^{a}$ & $(22)$ & $(6)$ & $(12)$ & (13) \\
\hline $\begin{array}{l}\text { Fall backs prior to } 1 \text { November } \\
\text { (number of fish) }\end{array}$ & $\begin{array}{c}23 \\
(22)\end{array}$ & $\begin{array}{l}5 \\
(5)\end{array}$ & $\begin{array}{c}11 \\
(11)\end{array}$ & $\begin{array}{c}11 \\
(11)\end{array}$ \\
\hline $\begin{array}{l}\text { Number of fall backs that } \\
\text { survived }\end{array}$ & 22 & 4 & $10^{b}$ & $11^{c}$ \\
\hline $\begin{array}{l}\text { Number of fall backs that may } \\
\text { not have survived }\end{array}$ & 1 & 1 & 1 & 0 \\
\hline $\begin{array}{l}\text { Fall backs after } 31 \text { October } \\
\text { (number of fish) }\end{array}$ & $\begin{array}{c}0 \\
(0)\end{array}$ & $\begin{array}{l}1 \\
(1)\end{array}$ & ${ }_{(2)}^{2}$ & $(3)^{5}$ \\
\hline $\begin{array}{l}\text { Number of fall backs that } \\
\text { survived }\end{array}$ & 0 & 0 & 1 & 2 \\
\hline $\begin{array}{l}\text { Number of fall backs that may } \\
\text { not have survived }\end{array}$ & 0 & 1 & 1 & 3 \\
\hline
\end{tabular}

a A total of 36 individual salmon fell back at Snake River dams in 1992. This includes six fish tagged at LGR. The breakdown for fall backs by LGR tagged salmon is as follows: 5 fall backs at LGO and 5 at LGR that were survived prior to 1 November, one fall back at LGR after 31 October that was survived and one that may not have been.

b A radio transmitter from a salmon tagged at LGR was recovered in the juvenile fish bypass at LGO.

c One tagged fish (CHAR) was possibly flushed out of the trap to below the dam after it was recaptured at the LGR trap.

' One of these fish also fell back prior to 1 November. 


\section{CONCLUSIONS}

We believe that fall chinook salmon radio tagged in 1992 accurately represent the movements of untagged fall chinook salmon in the snake River, particularly upstream of IHR Dam. Our conclusions are supported by similar rates of fish "loss" between IHR and LGR dams for tagged and untagged fall chinook salmon passage, and the documentation of frequency of fall back of unmarked fall chinook at LGO and LGR dams. However, we can not be sure that we are able to adequately assess salmon passage behavior at IHR Dam with fish radio tagged and released near there. For example, we noted during 1991 and 1992 that dam passage for radio tagged salmon was prolonged at IHR Dam, relative to other Snake River dams. Additionally, we cannot absolutely confirm that radio tagged salmon that returned to the Columbia or Yakima rivers represent the behavior (fell back or returned downstream) in the same proportions as salmon that were not captured and tagged. Although, we do have circumstantial evidence from dam counts that suggests that many salmon that were not radio tagged may have returned downstream after crossing IHR Dam in 1992. To adequately address these uncertainties regarding salmon passage at IHR it may be necessary to capture, radio tag, and release salmon a substantial distance downriver of IHR Dam (eg. at McNary or John Day dams). These radio tagged salmon would then be "naive" to IHR Dam and they should demonstrate natural behavior there.

Fall back at dams was quite common for radio tagged salmon during 1991 (Mendel et al. 1992) and 1992. We determined that approximately $62 \%$ of the salmon that could not be accounted for between IHR and LGR dams was probably attributable to fall back at IHR dam. Many of these fish were obviously alive after falling back at IHR because they apparently spawned in the Yakima River or the Hanford Reach of the Columbia River. Additionally, we estimated that approximately 35\% of the salmon that could not be accounted for upstream of LGR Dam fell back at that dam in 1992. These data provide us with some insight as to why the adult-per-redd ratios upstream of LGR Dam have been higher than expected in past years.

Radio telemetry did identify possible new spawning sites for two fish upstream of LGR Dam, but spawning in the tailraces of Snake River Dams could not be determined. We estimated adultper-redd ratios of 4.9 upstream of LGR when fish that fell back at LGR and fish that were "lost" in the reservoir were factored into the estimate. We recommend that redd surveys be extended a few kilometers upstream of Troy in 1993 because of the recovery of a radio tagged salmon there in 1992 . 
Most importantly, we find that counts of fall chinook salmon at IHR and LGR dams apparently provide inflated estimates of the actual number of this federally listed (threatened) salmon that remain within the Snake River basin. We have not yet attempted to estimate the error rate of the counts because the estimate is complicated by the incidence of multiple fall backs of individual fish and recrossing of dams as some fish return upstream. We believe that uncorrected counts of salmon as they cross lower Snake River dams provide unrealistically high estimates of fall chinook salmon that remain in the Snake River drainage to spawn. 


\section{REFERENCES}

Bjornn, T., R. Ringe, K. Tolotti, P. Keniry, and J. Hunt. 1992. Migration of adult chinook and steelhead past dams and through reservoirs in the lower snake River and into tributaries - 1991. Technical Report 92-2. To the Walla District U.S. Army Corps of Engineers. Walla, WA

Blankenship, L. 1993. Stock identification of fall chinook salmon in the Snake River. In Blankenship, L. and G. Mendel, (Editors). 1993. Upstream passage, spawning, and stock identification of fall chinook salmon in the snake River. Annual Rept. FY 92-93. To Bonneville Power Administration. Project No. 92-46. Washington Department of Fisheries, Olympia, WA.

Connor et al. 1993. Fall chinook salmon spawning in free-flowing reaches of the snake River. In Rondorf, D. and W. Miller, 1993. Identification of the spawning, rearing, and migration requirements of fall chinook salmon in the Columbia River Basin. Annual Rept. FY 91-92. to Bonneville Power Administration. Project No. 91-029. US. Fish and Wildlife Service, Ahsahka, ID.

Corps of Engineers. 1993. Annual fish passage report, 1992, Columbia and Snake Rivers. North Pacific Division, US Army Corps of Engineers, Portland and Walla Districts.

Groves, P. 1993. Habitat available for, and used by, fall chinook salmon within the Hells Canyon Reach of the Snake River. Annual Progress Report, 1992. Environmental Affairs Department, Idaho Power Company, Boise, ID.

Mendel, G., D. Milks, R. Bugert, and K. Petersen. 1992. Upstream passage and spawning of fall chinook salmon in the Snake River, 1991. Completion Report to the US Fish and Wildlife Service, LSRCP. Rept. No. AFFl/LSR/92-11. Washington Department of Fisheries, Olympia, WA.

IYendel, G. K. Petersen, R. Bugert, D. Milks, L. Ross, J. Dedloff, L. LaVoy. 1992b. Lower Snake River Compensation Plan, Lyons Ferry fall chinook salmon hatchery program. 1991 Evaluation Report. Annual Rept. to the US Fish and Wildlife Service, Lower Snake River Compensation Plan Office, 4696 Overland Rd., Rm. 560, Boise, ID., Rept. No. AFFl/LSR/92-12. Washington Department of Fisheries, Olympia, WA. 
Mendel, G., J. Dedloff, L. Ross, R. Bugert, K. Petersen. 1992c. Fall chinook salmon trapping on the snake River in 1991. Annual Rept. to the US Fish and Wildlife Service, Lower Snake River Compensation Plan Office, 4696 Overland Rd., Rm. 560, Boise, ID., Rept. No. AFFl/LSR/92-7. Washington Department of Fisheries, Olympia, WA.

Mendel, G., L. Ross, R. Bugert. 1993. Fall chinook salmon trapping on the Snake River in 1992. (Draft) Annual Rept. to the US Fish and Wildlife Service, Lower Snake River Compensation Plan Office, 4696 Overland Rd., Rm. 560, Boise, ID., Cooperative Agreement No. 14-16-0001-92542. Washington Department of Fisheries, Olympia, WA.

Mendel, G., K. Petersen, R. Bugert, D. Milks, L. Ross, J. Dedloff, and J. Bumgarner. 1993b. Lyons Ferry fall chinook salmon hatchery evaluation program, 1992 Annual Report

(Draft) to U.S. Fish and Wildlife Service, Lower Snake River Compensation Plan Office, 4696 Overland Rd., Rm. 560, Boise, ID., Cooperative Agreement 14-16-0001-91534. WA Dept. of Fisheries, Olympia, WA.

Wagner, P. 1991. 1990 Evaluation of the use of the McNary bypass system to divert adult fallbacks away from turbine intakes. Final Report to US Army Corps of Engineers, modification to contract No. DACW68-82-C-0077, Task Order No. 9., Washington Department of Fisheries, Olympia, WA.

Wagner, P. and T. Hillson. 1992. 1991 Evaluation of the use of the McNary bypass system to divert adult fallbacks away from turbine intakes. Final Report to US Army Corps of Engineers, modification to contract No. DACW68-82-C-0077, Task Order No. 10., Washington Department of Fisheries, Olympia, WA. 


\section{APPENDIX A}

Landmarks and river kilometer (RK) locations used in this report.

\begin{tabular}{|c|c|}
\hline River kilometer & Location \\
\hline $\begin{array}{l}\text { Columbia River } \\
346.9 \\
389.1 \\
450.5 \\
464.7 \\
469.8 \\
479.6 \\
504.4 \\
521.8 \\
539.3 \\
540.8 \\
571.2 \\
595.2 \\
624.3 \\
635.6 \\
638.8\end{array}$ & $\begin{array}{l}\text { Jbhn Day Dam } \\
\text { Arlington } \\
\text { Irrigon Fish Hatchery } \\
\text { Umatilla River } \\
\text { McNary Dam } \\
\text { Hat Rock Park } \\
\text { Walla River } \\
\text { Snake River } \\
\text { Yakima River } \\
\text { Hwy } 182 \text { Bridge (Richland) } \\
\text { Ringold } \\
\text { White Bluffs } \\
\text { Vernita Bridge } \\
\text { Priest Rapids Fish Hatchery } \\
\text { Priest Rapids Dam }\end{array}$ \\
\hline $\begin{array}{r}\text { Snake River } \\
0.0 \\
3.7 \\
16.1 \\
18.3 \\
62.3 \\
66.9 \\
95.1 \\
95.7 \\
100.1 \\
113.1 \\
133.9 \\
173.0 \\
178.1 \\
192.4 \\
198.7 \\
206.3 \\
210.1 \\
224.1 \\
233.8 \\
241.8 \\
250.2 \\
253.6 \\
261.5 \\
265.3 \\
271.4 \\
302.8 \\
308.4 \\
397.4\end{array}$ & $\begin{array}{l}\text { Mouth } \\
\text { Hood Park } \\
\text { Ice Harbor Dam } \\
\text { Charbonneau Park } \\
\text { Windust Park } \\
\text { Lower Monumental Dam } \\
\text { Lyons Ferry Fish Hatchery } \\
\text { Palouse River } \\
\text { Tucannon River } \\
\text { Little Goose Dam } \\
\text { Central Ferry Bridge } \\
\text { Lower Granite Dam } \\
\text { Wawawai Park } \\
\text { Blyton Landing } \\
\text { Nisqually John Landing } \\
\text { Steptoe Creek } \\
\text { Alpowa Creek } \\
\text { Clearwater River } \\
\text { Asotin Creek } \\
\text { lo Mile Creek } \\
\text { Redbird Creek } \\
\text { Couse Creek } \\
\text { Captain John Creek } \\
\text { Billy Creek } \\
\text { Grande Ronde River } \\
\text { Salmon River } \\
\text { Imnaha River } \\
\text { Hells Canvon Dam }\end{array}$ \\
\hline
\end{tabular}


Appendix A, continued.

\begin{tabular}{|c|c|}
\hline River kilometer & Location \\
\hline \multicolumn{2}{|l|}{ Yakima River } \\
\hline 0.0 & Mouth \\
\hline 3.4 & 240 Bridge \\
\hline 7.2 & I-82 Bridge \\
\hline 13.5 & Van Giesen Bridge \\
\hline 21.2 & Twin Bridges \\
\hline 29.0 & Horn Rapids Dam \\
\hline 42.9 & Songbird Island \\
\hline 47.9 & Benton City Bridge \\
\hline 56.2 & Kiona Diversion Dam \\
\hline 76.4 & Prosser Dam \\
\hline 129.5 & Toppenish Creek \\
\hline 132.6 & Marion Drain \\
\hline 146.4 & Zillah/Toppenish Bridge \\
\hline 149.8 & Toppenish/Buena Bridge \\
\hline 157.8 & Sawyer \\
\hline \multicolumn{2}{|l|}{ Clearwater River } \\
\hline 0.0 & Mouth \\
\hline 7.4 & Potlatch Mill \\
\hline 11.3 & Hatwai Creek \\
\hline 19.3 & Hwy 95 Bridge \\
\hline 24.0 & Hwy 12 Bridge \\
\hline 26.4 & Gibbs Eddy \\
\hline 29.4 & Myrtle Bridge \\
\hline 34.4 & Cherry Lane Bridge \\
\hline 42.3 & Bedrock Creek \\
\hline 46.3 & Lenore \\
\hline 56.6 & Peck \\
\hline 65.1 & Dworshak Hatchery \\
\hline 71.8 & Orofino Bridge \\
\hline 87.0 & Lolo Creek \\
\hline 95.7 & Six Mile Creek \\
\hline 107.8 & Kamiah \\
\hline 120.2 & South Fork of Clearwater \\
\hline
\end{tabular}




\section{APPENDIX}

Table 1. Data for fall chinook salmon radio tagged and released at Hood Park (RK 3.7), downstream of Ice Harbor Dam, 1992.

\begin{tabular}{|c|c|c|c|c|c|c|}
\hline $\begin{array}{l}\text { Tagging } \\
\text { Date }\end{array}$ & Code & $\begin{array}{c}\text { Jaw tag } \\
\text { no. }\end{array}$ & Sex & $\begin{array}{c}\text { Fork } \\
\text { length } \\
\text { (cm) }\end{array}$ & $\begin{array}{l}\text { Scale } \\
\text { age }\end{array}$ & Comments \\
\hline \multicolumn{7}{|c|}{ Channel 01} \\
\hline $10 / 02 / 92$ & 02 & B3160 & $\mathrm{F}$ & 67.0 & $3 / 1$ & \\
\hline $10 / 04 / 92$ & 09 & B4814 & M & 92.0 & $4 / 1$ & \\
\hline $09 / 16 / 92$ & 10 & 0318 & $\mathrm{~F}$ & 78.0 & & \\
\hline $10 / 26 / 92$ & 10 & B4856 & M & 104.0 & $5 / 1$ & Reused radio \\
\hline $10 / 03 / 92$ & 11 & B4860 & M & 105.0 & $4 / 1$ & \\
\hline $10 / 03 / 92$ & 13 & B3152 & $\mathrm{F}$ & 64.0 & $3 / 1$ & \\
\hline $10 / 05 / 92$ & 14 & W781 & M & 70.0 & $3 / 1$ & \\
\hline $09 / 30 / 92$ & 19 & W780 & M & 68.0 & $3 / 1$ & \\
\hline $10 / 03 / 92$ & 20 & B3162 & F & 68.0 & $3 / 1$ & \\
\hline $09 / 27 / 92$ & 22 & W864 & $\mathrm{F}$ & 81.0 & & \\
\hline $09 / 26 / 92$ & 23 & W798 & M & 65.5 & & \\
\hline $10 / 19 / 92$ & 24 & W778 & F & 80.0 & $3 / 1$ & \\
\hline $09 / 15 / 92$ & 27 & A2545 & $\mathrm{F}$ & 86.0 & $4 / 1$ & \\
\hline $10 / 27 / 92$ & 29 & B4 907 & $\mathrm{M}$ & 90.0 & $4 / 1$ & \\
\hline $10 / 26 / 92$ & 31 & W866 & $\mathrm{F}$ & 89.0 & $5 / 1$ & Reused radio \\
\hline $10 / 11 / 92$ & 32 & W879 & $\mathrm{F}$ & 82.5 & $4 / 1$ & \\
\hline $10 / 17 / 92$ & 35 & w797 & $\mathrm{M}$ & 70.5 & $3 / 1$ & \\
\hline $10 / 02 / 92$ & 41 & B3170 & $\mathrm{M}$ & 73.0 & $3 / 1$ & \\
\hline $09 / 20 / 92$ & 42 & W887 & $\mathrm{F}$ & 79.0 & & \\
\hline $09 / 21 / 92$ & 46 & W871 & $\mathrm{F}$ & 88.0 & & \\
\hline $10 / 19 / 92$ & 47 & w777 & $\mathrm{F}$ & 70.0 & $3 / 1$ & \\
\hline $09 / 18 / 92$ & 48 & w755 & $\mathrm{M}$ & 73.5 & $3 / 1$ & \\
\hline $09 / 14 / 92$ & 50 & 0387 & $\mathrm{M}$ & 72.0 & & \\
\hline \multicolumn{7}{|c|}{ Channel 02} \\
\hline $09 / 17 / 92$ & 01 & W889 & $\mathrm{M}$ & 86.0 & $4 / 1$ & \\
\hline $10 / 04 / 92$ & 03 & B3181 & $\mathrm{F}$ & 68.5 & $4 / 2$ & \\
\hline $10 / 01 / 92$ & 06 & W880 & $\mathrm{F}$ & 79.0 & $4 / 2$ & \\
\hline $09 / 16 / 92$ & 07 & 1899 & $\mathrm{M}$ & 85.5 & $4 / 1$ & \\
\hline $09 / 16 / 92$ & 09 & 0319 & $\mathrm{M}$ & 72.0 & $3 / 1$ & \\
\hline $10 / 17 / 92$ & 10 & W886 & $\mathrm{F}$ & 88.0 & $4 / 1$ & \\
\hline $09 / 21 / 92$ & 11 & W875 & $\mathrm{F}$ & 82.0 & & \\
\hline $09 / 15 / 92$ & 14 & A254 6 & $\mathrm{~F}$ & 82.5 & $4 / 1$ & \\
\hline $10 / 05 / 92$ & 16 & W782 & $\mathrm{F}$ & 69.5 & $3 / 1$ & \\
\hline $09 / 17 / 92$ & 17 & w753 & $\mathrm{M}$ & 68.5 & $3 / 1$ & \\
\hline $09 / 20 / 92$ & 18 & B4812 & $\mathrm{M}$ & 87.0 & & \\
\hline $09 / 17 / 92$ & 19 & w754 & $\mathrm{M}$ & 71.0 & $3 / 1$ & \\
\hline $10 / 11 / 92$ & 23 & W868 & M & 81.5 & $3 / 1$ & \\
\hline $09 / 27 / 92$ & 24 & W7 62 & $\mathrm{~F}$ & 75.0 & & \\
\hline $09 / 15 / 92$ & 25 & A2556 & $\mathrm{F}$ & 80.0 & $4 / 2$ & \\
\hline $09 / 16 / 92$ & 26 & 1895 & $\mathrm{~F}$ & 94.0 & $5 / 1$ & \\
\hline $10 / 01 / 92$ & 27 & W863 & M & 91.0 & $4 / 1$ & \\
\hline
\end{tabular}


Appendix B, continued.

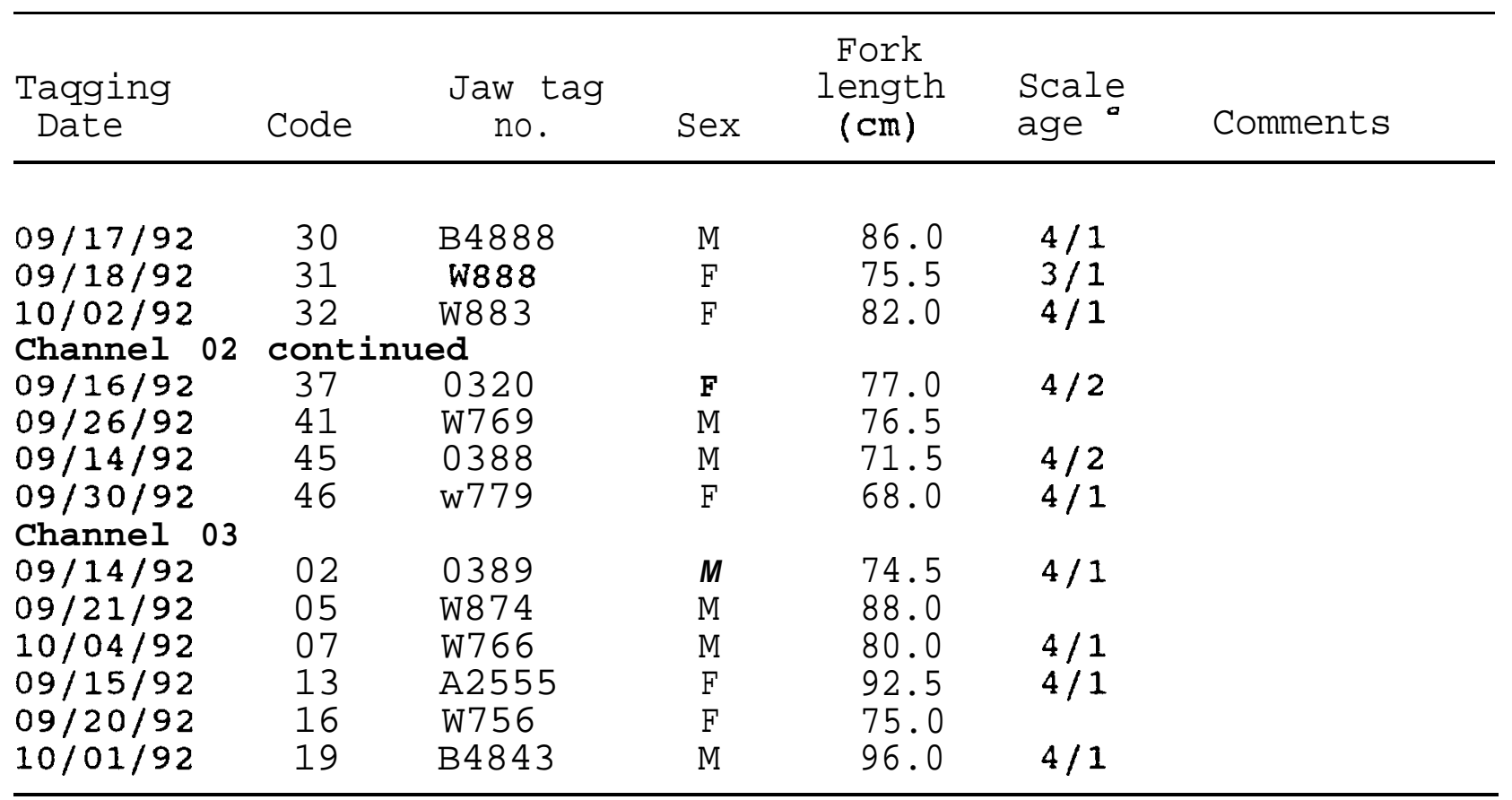

a Total age/years in fresh water. 
Appendix B, continued.

Table 2. Data for fall chinook salmon radio tagged and released at Charbonneau Park (RK 18.3), upstream of Ice Harbor Dam, 1992.

\begin{tabular}{|c|c|c|c|c|c|c|}
\hline $\begin{array}{l}\text { Tagging } \\
\text { Date }\end{array}$ & Code & $\begin{array}{c}\text { Jaw tag } \\
\text { no. }\end{array}$ & Sex & $\begin{array}{c}\text { Fork } \\
\text { length } \\
\text { (cm) }\end{array}$ & $\begin{array}{l}\text { Scale } \\
\text { age }\end{array}$ & Comments \\
\hline \multicolumn{7}{|c|}{ Channel 01} \\
\hline $10 / 08 / 92$ & 01 & W790 & M & 89.5 & $5 / 1$ & \\
\hline $10 / 09 / 92$ & 04 & w794 & $M$ & 74.5 & $4 / 2$ & \\
\hline $09 / 10 / 92$ & 05 & W852 & M & 95.0 & & \\
\hline $09 / 29 / 92$ & 06 & W7 64 & $\mathrm{~F}$ & 71.5 & & \\
\hline $10 / 09 / 92$ & 07 & w793 & F & 67.5 & & \\
\hline $10 / 06 / 92$ & 15 & B4842 & M & 101.0 & $4 / 1$ & \\
\hline $10 / 30 / 92$ & 16 & B4999 & $\mathrm{F}$ & 89.0 & $4 / 1$ & \\
\hline $10 / 10 / 92$ & 17 & W770 & $\mathrm{F}$ & 87.0 & $4 / 1$ & \\
\hline $09 / 25 / 92$ & 18 & B4 813 & $\mathrm{M}$ & 94.0 & & \\
\hline $10 / 08 / 92$ & 21 & W787 & $\mathrm{M}$ & 68.0 & & \\
\hline $09 / 28 / 92$ & 26 & W854 & $\mathrm{F}$ & 93.0 & $5 / 1$ & \\
\hline $09 / 11 / 92$ & 28 & W853 & $\mathrm{F}$ & 92.0 & $5 / 1$ & \\
\hline $09 / 12 / 92$ & 31 & W752 & $\mathrm{M}$ & 76.5 & $5 / 1$ & \\
\hline $09 / 22 / 92$ & 34 & W878 & $\mathrm{F}$ & 86.0 & & \\
\hline $09 / 13 / 92$ & 36 & B4850 & $\mathrm{M}$ & 90.5 & $5 / 2$ & \\
\hline $10 / 21 / 92$ & 38 & W884 & $\mathrm{M}$ & 75.0 & $3 / 1$ & \\
\hline $09 / 19 / 92$ & 39 & w799 & $\mathrm{F}$ & 71.5 & $3 / 1$ & \\
\hline $10 / 08 / 92$ & 43 & w773 & M & 74.0 & $3 / 1$ & \\
\hline $10 / 28 / 92$ & 44 & W785 & F & 78.0 & $4 / 2$ & \\
\hline $09 / 11 / 92$ & 45 & B4889 & M & 107.5 & $5 / 1$ & \\
\hline $09 / 23 / 92$ & 49 & W881 & $\mathrm{F}$ & 88.0 & & \\
\hline \multicolumn{7}{|c|}{ Channel 02} \\
\hline $10 / 12 / 92$ & 04 & w771 & $\mathrm{M}$ & 68.5 & $3 / 1$ & \\
\hline $09 / 24 / 92$ & 05 & W760 & $\mathrm{F}$ & 73.0 & & \\
\hline $09 / 25 / 92$ & 08 & W7 61 & $\mathrm{~F}$ & 77.0 & & \\
\hline $09 / 29 / 92$ & 12 & W7 67 & $\mathrm{M}$ & 69.0 & $3 / 1$ & \\
\hline $10 / 09 / 92$ & 15 & W865 & $M$ & 80.0 & $3 / 1$ & \\
\hline $10 / 18 / 92$ & 21 & B4 825 & $\mathrm{M}$ & 101.0 & $4 / 1$ & \\
\hline $10 / 08 / 92$ & 22 & w791 & $\mathrm{F}$ & 71.0 & $4 / 2$ & \\
\hline $10 / 10 / 92$ & 28 & B 4846 & $\mathrm{M}$ & 102.5 & $4 / 1$ & \\
\hline $10 / 08 / 92$ & 29 & w792 & $\mathrm{F}$ & 73.0 & $4 / 2$ & \\
\hline $09 / 19 / 92$ & 35 & B4 810 & $\mathrm{M}$ & 88.0 & $4 / 1$ & \\
\hline $09 / 23 / 92$ & 43 & W872 & $\mathrm{M}$ & 82.0 & & \\
\hline $09 / 24 / 92$ & 47 & w759 & $\mathrm{F}$ & 74.5 & & \\
\hline $09 / 13 / 92$ & 48 & B4841 & $\mathrm{M}$ & 105.5 & $4 / 1$ & \\
\hline $09 / 28 / 92$ & 50 & B4887 & $\mathrm{M}$ & 93.0 & $4 / 1$ & \\
\hline
\end{tabular}


Appendix B, continued.

\begin{tabular}{|c|c|c|c|c|c|c|}
\hline $\begin{array}{c}\text { Tagging } \\
\text { Date }\end{array}$ & Code & $\begin{array}{c}\text { Jaw tag } \\
\text { no. }\end{array}$ & Sex & $\begin{array}{c}\text { Fork } \\
\text { length } \\
\text { (cm) }\end{array}$ & $\begin{array}{l}\text { Scale } \\
\text { age }\end{array}$ & Comments \\
\hline \multicolumn{7}{|c|}{ Channel 03} \\
\hline $\begin{array}{l}10 / 06 / 92 \\
09 / 13 / 92 \\
09 / 19 / 92 \\
09 / 23 / 92\end{array}$ & $\begin{array}{l}11 \\
12 \\
14 \\
15\end{array}$ & $\begin{array}{l}\text { W8 } 62 \\
\text { B4808 } \\
\text { B4811 } \\
\text { W776 }\end{array}$ & $\begin{array}{l}\mathrm{M} \\
\mathrm{F} \\
\mathrm{F} \\
\mathrm{F}\end{array}$ & $\begin{array}{r}101.0 \\
103.5 \\
91.0 \\
71.0\end{array}$ & $\begin{array}{l}5 / 1 \\
4 / 1 \\
6 / 1\end{array}$ & \\
\hline $\begin{array}{l}09 / 13 / 92 \\
10 / 30 / 92 \\
09 / 22 / 92\end{array}$ & $\begin{array}{l}17 \\
18 \\
20\end{array}$ & $\begin{array}{l}\text { B4809 } \\
\text { W855 } \\
\text { W758 }\end{array}$ & $\begin{array}{l}\mathrm{F} \\
\mathrm{F} \\
\mathrm{M}\end{array}$ & $\begin{array}{l}87.0 \\
81.0 \\
64.5\end{array}$ & $\begin{array}{l}4 / 1 \\
4 / 1\end{array}$ & \\
\hline
\end{tabular}

a Total age/years in fresh water. 
Figure 1. Flow chart summarizing radio telemetry data for fall chinook salmon trapped at Ice Harbor Dam and released at Hood Park (12.4 km downstream of the dam) in 1992 (53 fish)

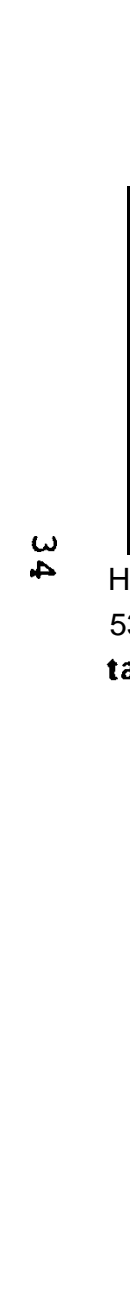

LFH spawned, 1 fish, (1/10a)

$\left.\right|_{\text {HPK }} ^{11 \text { fish }}$

53 fish

tagged

IHR

Below LGO

10 fish

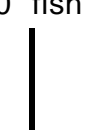

lelow L
$\Gamma^{4 \text { fish }}$

To LGO

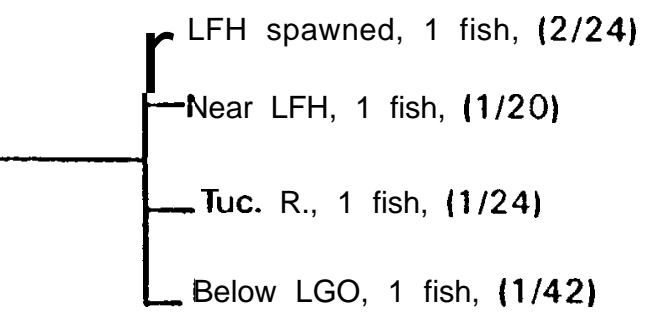

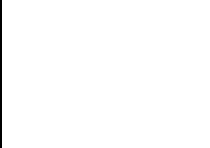

Above LGO

6 fish

G B LMO forebay

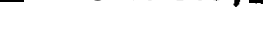
- Near LFH, (2/3)

$\begin{array}{ll}\text { HPK } & \text { = Hood Park } \\ \text { IHR } & =\text { Ice Harbor Dam } \\ \text { LMO } & =\text { Lower Monumental Dam } \\ \text { LGO } & =\text { Little Goose Dam } \\ \text { LGR } & =\text { Lower Ganite Dam } \\ \text { LFH } & =\text { Lyons Ferry Hatchery } \\ \text { Col. R. } & =\text { Columbia River } \\ \text { Clw. R. } & =\text { Clearwater River } \\ \text { Gr. Ronde R. } & =\text { Grande Ronde River } \\ \text { Yak. R. } & =\text { Yakima River } \\ \text { Tuc. R. } & =\text { Tucannion River } \\ & \end{array}$

B elow LGR- LGR Adult trap

Near Asotin

-Below LGR -

LGR Adult trap Below LGR, (1/46) Snake $R$

1 fish Clw. R.

above Asotin

Clw. R. - Snake R. below - Clw. R. Gr. Ronde R $\quad(2 / 31)$

- Above Asotin Below LGR, (1/27)

1 fish

L Snake R. below $L F H$, returned to river, $(1 / 23)$

Asotin, 1 fish

L.LGR, 1 fish, not observed__ Above Asotin

Clw. R. -Above Captain John Cr., (3/5) 
Appendix C, Figure 1, continued.

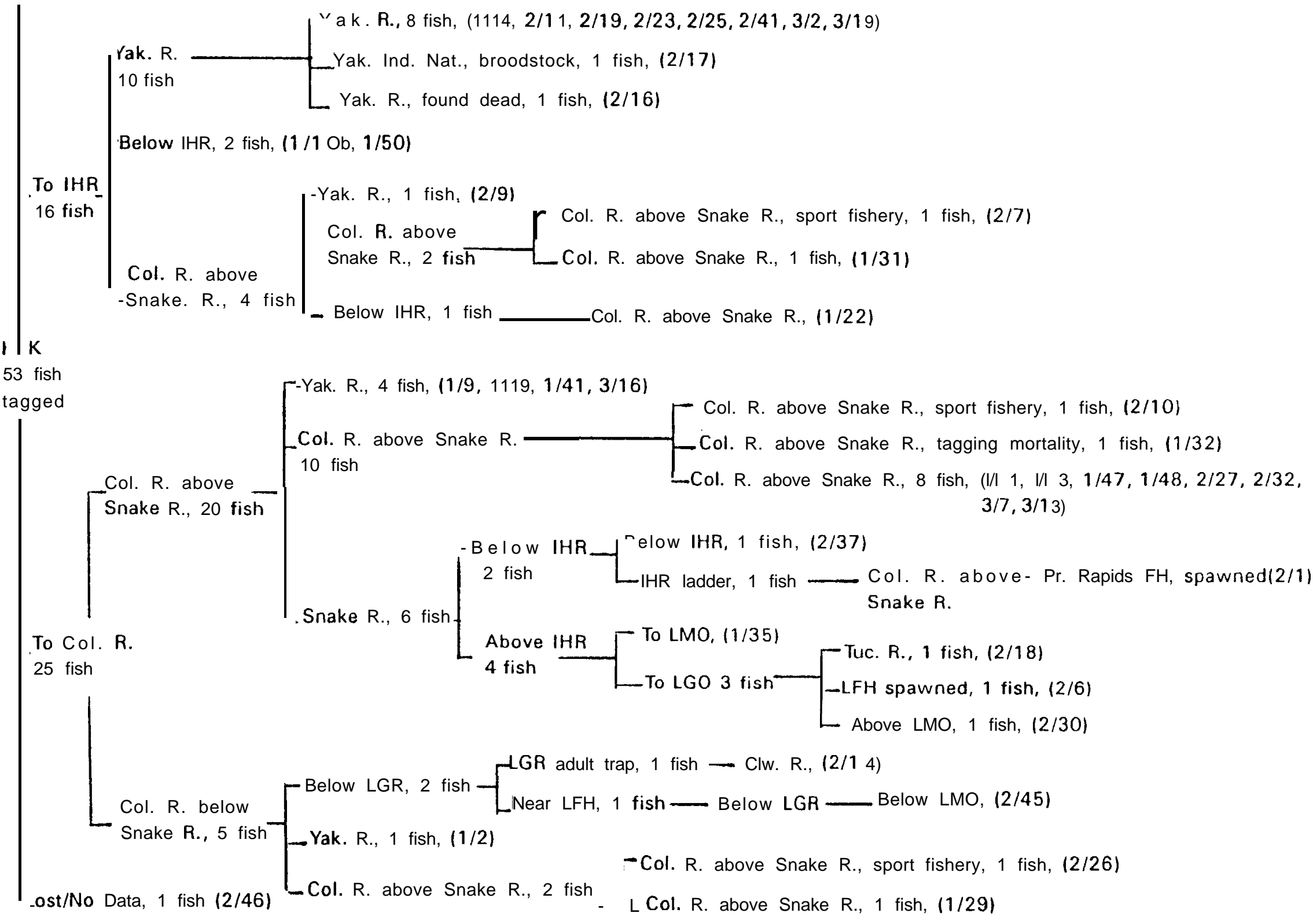


Appendix C, continued.

Figure 2. Flow chart summarizing radio telemetry data for fall

chinook salmon trapped at Ice Harbor Dam and released at

Charbonneau Park (2.2 km upstream of the dam) in 1992 (43 fish).

Snake R. below

mouth of Tuc R

LFH spawned, $(1 / 31)$

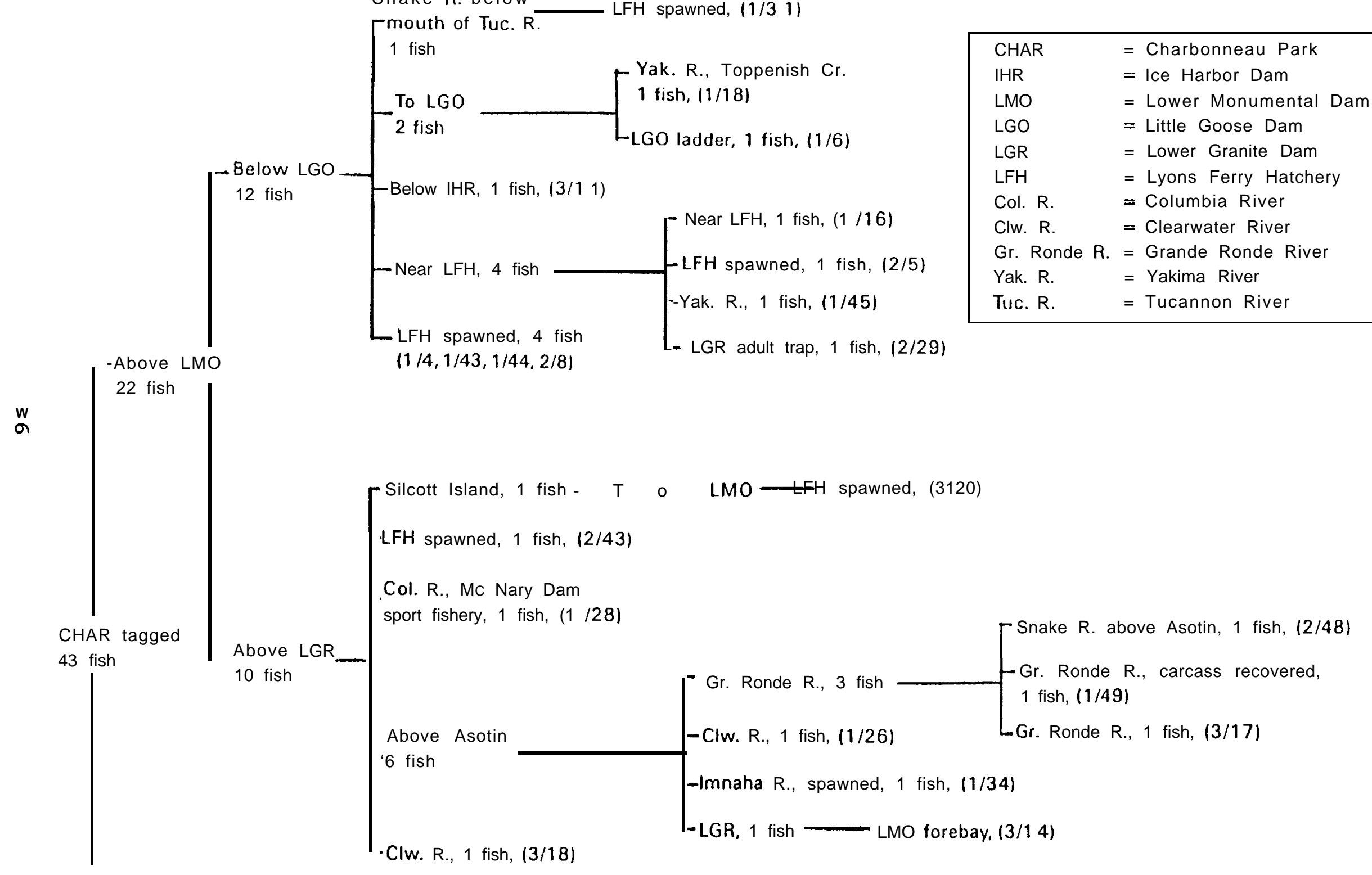




\section{Appendix C, Figure 2, continued.}

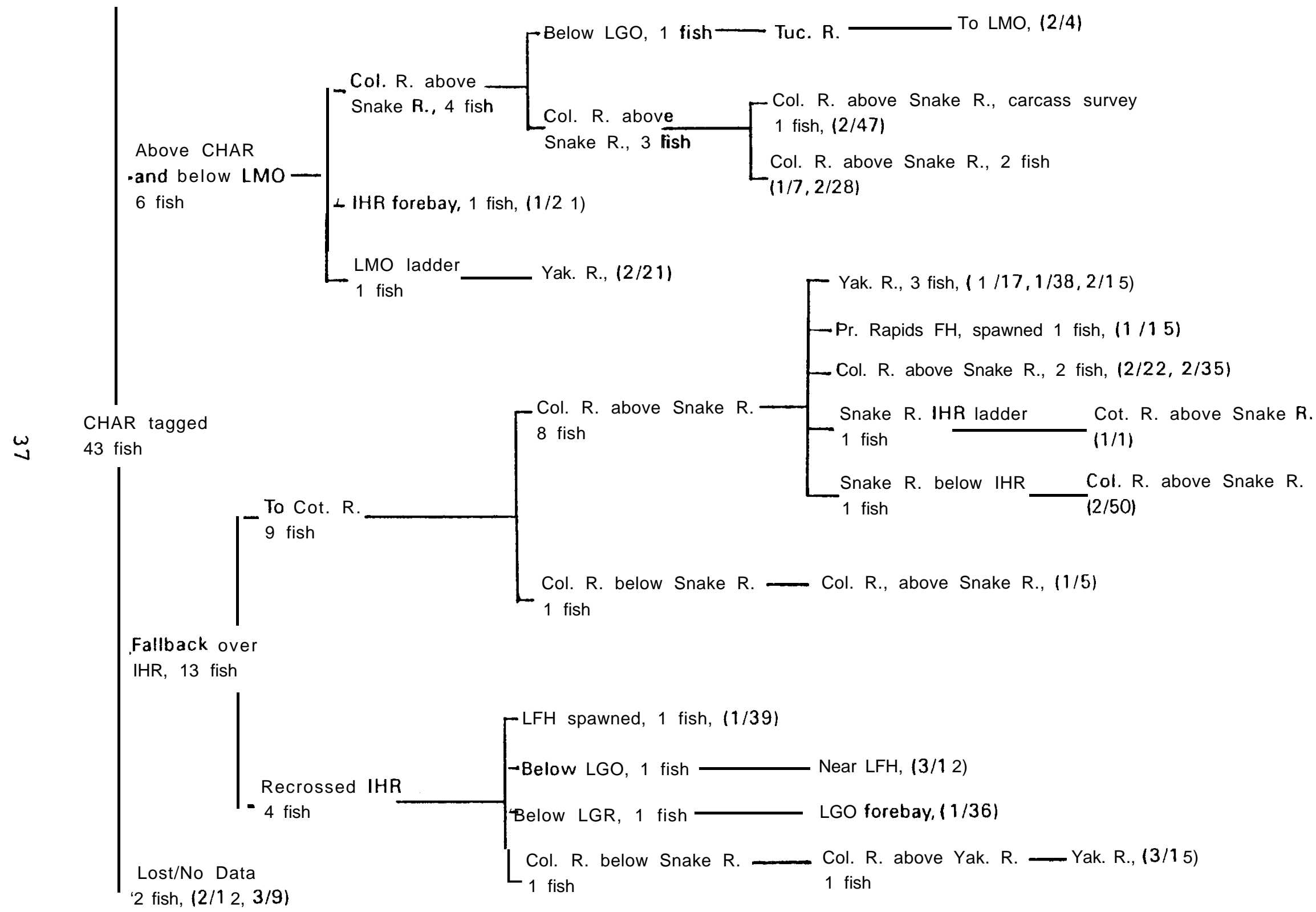




\section{Appendix C, continued.}

Figure 3. Flow chart summarizing radio telemetry data for fall chinook salmon trapped at Lower Granite Dam in 1992 (20 fish released above the trap in the south fish ladder).

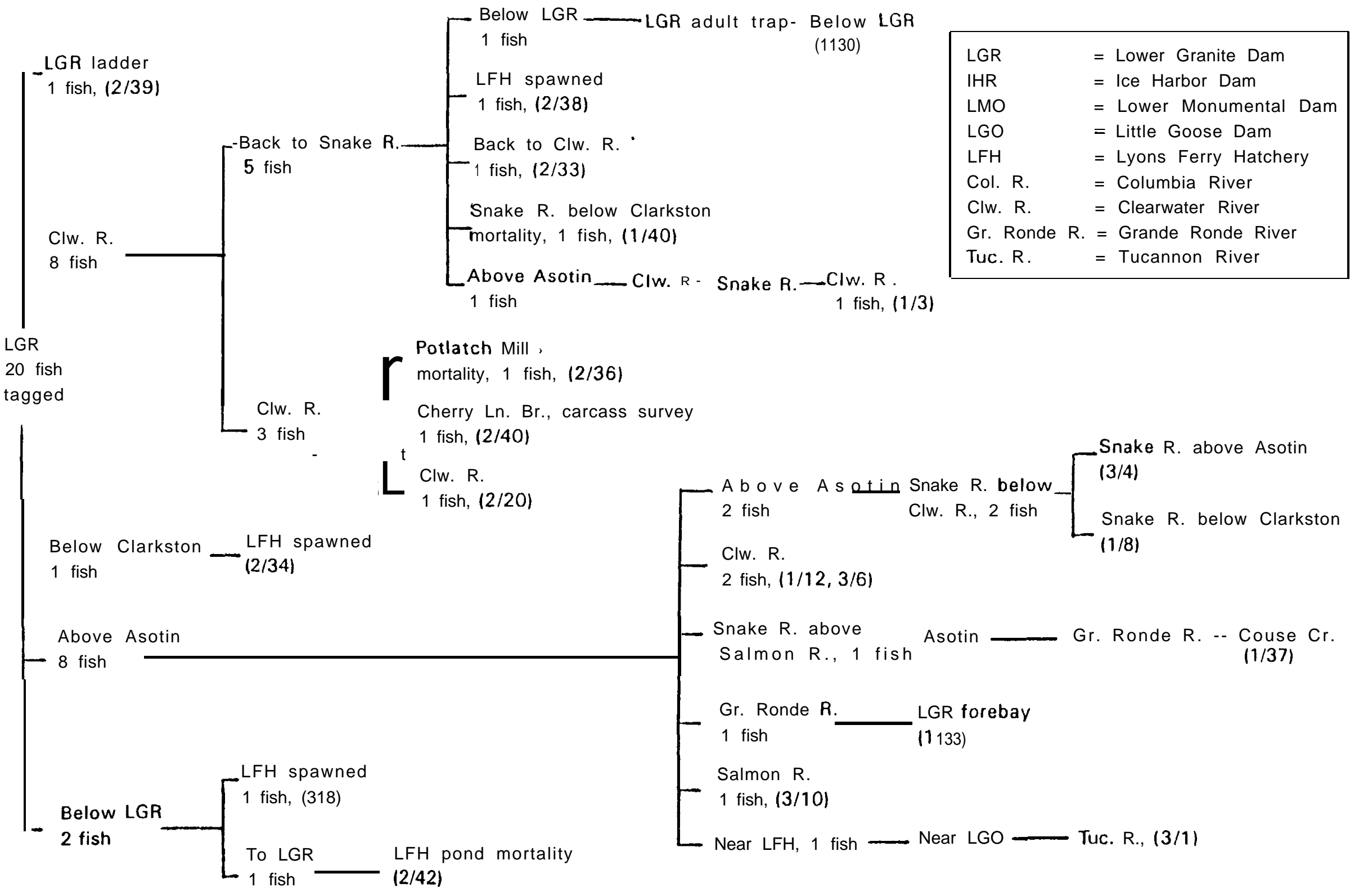




\section{APPENDIX D}

Summary of radio telemetry data for radio tagged fall chinook salmon trapped at Ice Harbor and Lower Granite Dams. Release sites were Hood Park (HPK: RK 3.7), Charbonneau Park (CHAR: RK 18.3), and Lower Granite Trap (LGR, RK 172.2). (IHR=Ice Harbor Dam, LMO=Lower Monumental Dam, LGO=Little Goose Dam, LGR=Lower Granite Dam, Col. R.=Columbia River, Yak. R.=Yakima River, Tuc. R.=Tucannon River, CLW R.=Clearwater River, Gr. Ronde R.=Grande Ronde River, and LFH=Lyons Ferry Hatchery. Fish with no tracking data are not included in this Appendix. Note: () around dam indicates no detections are available from fixed-site receivers at the dam to indicate a fish crossed the dam.

\begin{tabular}{|c|c|c|c|}
\hline Channel & Code & $\begin{array}{l}\text { Dates } \\
\text { (month/day) }\end{array}$ & Comments \\
\hline$\overline{01}$ & 01 & $\begin{array}{l}10 / 8 \\
10 / 15 \\
10 / 26 \\
10 / 30 \\
11 / 9 \\
12 / 9\end{array}$ & 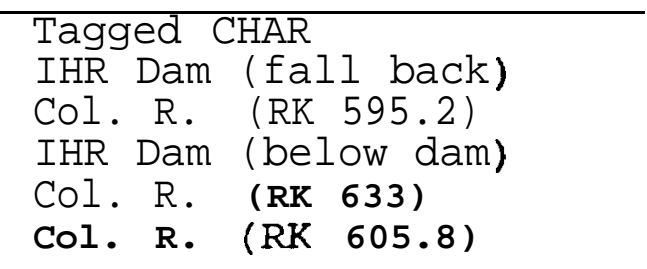 \\
\hline 01 & 02 & $\begin{array}{l}10 / 2 \\
10 / 5-21 \\
11 / 9-12 / 15 \\
12 / 23\end{array}$ & $\begin{array}{l}\text { Tagged } \text { HPK } \\
\text { Col. R. } \\
\text { Yak. } \\
\text { Yak } 491.1-502.8) \\
\text { Yak. R. }\end{array}$ \\
\hline 01 & 03 & $\begin{array}{l}9 / 22 \\
9 / 24 \\
9 / 28-10 / 4 \\
10 / 7 \\
10 / 9-15 \\
10 / 15-16 \\
10 / 16-12 / 1 \\
12 / 10\end{array}$ & $\begin{array}{l}\text { Tagged LGR } \\
\text { LGR Dam } \\
\text { CWR R. (RK 7.6-30.1) } \\
\text { Snake R. (RK 237.1) } \\
\text { CWR R. (RK 7.6-45.1) } \\
\text { Snake R. (RK 227.8-237.1) } \\
\text { CWR R. (RK 6-49.7) } \\
\text { CWR R. (RK 8.4) }\end{array}$ \\
\hline 01 & 04 & $\begin{array}{l}10 / 9 \\
10 / 26-11 / 17\end{array}$ & $\begin{array}{l}\text { Tagged CHAR } \\
\text { (LMO a Dam)-no data } \\
\text { LFH }\end{array}$ \\
\hline 01 & 05 & $\begin{array}{l}9 / 10 \\
9 / 15 \\
9 / 18-12 / 9 \\
12 / 15\end{array}$ & $\begin{array}{l}\text { Tagged CHAR } \\
\text { (IHR Dam)-fall back } \\
\text { Col. R. (RK 507.6) } \\
\text { Col. R. (RK } 553.5-599) \\
\text { Col. R. (RK 586.8) }\end{array}$ \\
\hline
\end{tabular}


Appendix D, continued.

\begin{tabular}{|c|c|c|c|}
\hline Channel & Code & $\begin{array}{l}\text { Dates } \\
(\text { month/day) }\end{array}$ & Comments \\
\hline$\overline{01}$ & 06 & $\begin{array}{l}9 / 29 \\
10 / 15 \\
10 / 20-31\end{array}$ & $\begin{array}{l}\text { Tagged CHAR } \\
\text { (LMo Dam)-no data } \\
\text { Snake R. at the mouth } \\
\text { of the Palouse R. } \\
\text { LGo Dam (below dam) }\end{array}$ \\
\hline 01 & 07 & $\begin{array}{l}10 / 9 \\
10 / 15 \\
10 / 21 \\
11 / 9\end{array}$ & $\begin{array}{l}\text { Tagged CHAR } \\
\text { Snake R. (RK } 47.5) \\
\text { IHR Dam } \\
\text { (IHR Dam)-fall back } \\
\text { Col. R. (RK 624.5) }\end{array}$ \\
\hline 01 & 08 & $\begin{array}{l}10 / 15 \\
10 / 17 \\
10 / 24-26 \\
11 / 10-12 / 11 \\
12 / 19\end{array}$ & $\begin{array}{l}\text { Tagged LGR } \\
\text { LGR Dam } \\
\text { Snake R. (RK 237.1) } \\
\text { Snake R. (RK 195-207.9) } \\
\text { Snake R. (RK 192) }\end{array}$ \\
\hline 01 & 09 & $\begin{array}{l}10 / 4 \\
12 / 3 \\
12 / 15\end{array}$ & $\begin{array}{l}\text { Tagged } \text { HPK } \\
\text { Yak. R. }\left(\begin{array}{ll}\text { RK } & 20.9\end{array}\right) \\
\text { Yak. R. }\end{array}$ \\
\hline 01 & 10 & $\begin{array}{l}9 / 16 \\
9 / 16-25 \\
9 / 28 \\
10 / 1-11 / 9\end{array}$ & $\begin{array}{l}\text { Tagged HPK } \\
\text { IHR Dam } \\
\text { (LMO Dam)-no data } \\
\text { Snake R. (RK 93.5) } \\
\text { LFH a b }\end{array}$ \\
\hline 01 & 10 & $\begin{array}{l}10 / 26 \\
10 / 26-11 / 3\end{array}$ & $\begin{array}{l}\text { Reused radio tag HPK } \\
\text { IHR Dam (did not cross) }\end{array}$ \\
\hline 01 & 11 & $\begin{array}{l}10 / 3 \\
10 / 5-12 / 9 \\
12 / 15\end{array}$ & 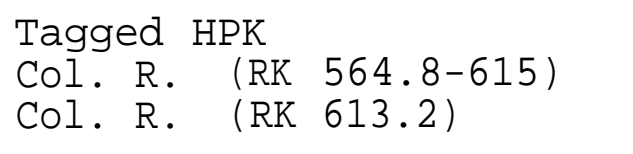 \\
\hline 01 & 12 & $\begin{array}{l}9 / 26 \\
10 / 1-13 \\
10 / 15 \\
10 / 19-30 \\
11 / 4-12 / 10 \\
12 / 10-1 / 6\end{array}$ & $\begin{array}{l}\text { Tagged LGR } \\
\text { (LGR Dam) -no data } \\
\text { Snake R. (RK 237.1-238.1) } \\
\text { Snake R. (RK 194.6) } \\
\text { Snake R. (RK 237.1) } \\
\text { CWR R. (RK 7.6-118.7) } \\
\text { CWR R. (RK 7.6) }\end{array}$ \\
\hline
\end{tabular}


Appendix D, continued.

\begin{tabular}{|c|c|c|c|}
\hline Channel & Code & $\begin{array}{l}\text { Dates } \\
\text { (month/day) }\end{array}$ & Comments \\
\hline$\overline{01}$ & 13 & $\begin{array}{l}10 / 3 \\
10 / 21 \\
10 / 26 \\
11 / 9\end{array}$ & 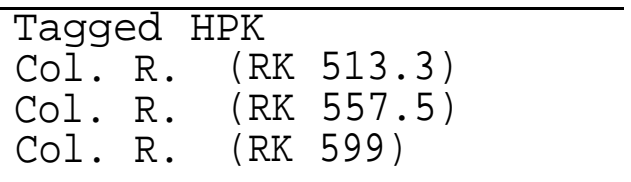 \\
\hline 01 & 14 & $\begin{array}{l}10 / 5 \\
10 / 26-27 \\
12 / 3-15 \\
12 / 23\end{array}$ & $\begin{array}{l}\text { Tagged HPK } \\
\text { IHR Dam (below dam) } \\
\text { Yak. R. (RK 7.7-12.1) } \\
\text { Yak. R. }(\text { RK 13) }\end{array}$ \\
\hline 01 & 15 & $\begin{array}{l}10 / 6 \\
11 / 4\end{array}$ & $\begin{array}{l}\text { Tagged CHAR } \\
\text { (IHR Dam)-fall back } \\
\text { Priest Rapids FH }\end{array}$ \\
\hline 01 & 16 & $\begin{array}{l}10 / 30 \\
10 / 31-11 / 1 \\
11 / 3 \\
11 / 7 \\
11 / 13\end{array}$ & $\begin{array}{l}\text { Tagged CHAR } \\
\text { LMO Dam } \\
\text { LFH } \\
\text { LGO Dam (below dam) } \\
\text { Near LFH (not recovered) }\end{array}$ \\
\hline 01 & 17 & $\begin{array}{l}10 / 10 \\
10 / 15 \\
11 / 7-12 / 15 \\
12 / 23\end{array}$ & $\begin{array}{l}\text { Tagged CHAR } \\
\text { IHR Dam } \\
\text { Yak. Rall back) } \\
\text { Yak. R. }(\text { RK } 1.0-6.4) \\
\text { RK 6.9) }\end{array}$ \\
\hline 01 & 18 & $\begin{array}{l}9 / 25 \\
9 / 28-10 / 1 \\
10 / 1 \\
12 / 23\end{array}$ & $\begin{array}{l}\text { Tagged CHAR } \\
\text { (LMO Dam)-no data } \\
\text { LGO Dam (below dam) } \\
\text { Snake R. (RK 100.4) } \\
\text { (LMO Dam)-fall back } \\
\text { (IHR Dam)-fall back } \\
\text { Toppenish Creek (RK 5.3) } \\
\text { on the Yak. R. (RK 129.4) }\end{array}$ \\
\hline 01 & 19 & $\begin{array}{l}9 / 30 \\
10 / 5 \\
11 / 9-12 / 15 \\
12 / 23\end{array}$ & $\begin{array}{l}\text { Tagged HPK } \\
\text { Col. R. } \quad(\text { RK 564.8) } \\
\text { Yak. R. }(\text { RK 27.4-47.6) } \\
\text { Yak. R. }(\text { RK 29) }\end{array}$ \\
\hline
\end{tabular}


Appendix D, continued.

\begin{tabular}{|c|c|c|c|}
\hline Channel & Code & $\begin{array}{l}\text { Dates } \\
\text { (month/day) }\end{array}$ & Comments \\
\hline$\overline{01}$ & 20 & $\begin{array}{l}10 / 3 \\
10 / 13 \\
10 / 15 \\
10 / 22-26 \\
10 / 29-30 \\
10 / 30 \\
11 / 3\end{array}$ & $\begin{array}{l}\text { Tagged HPK } \\
\text { IHR Dam } \\
\text { (Lmo Dam) } \text {-no data } \\
\text { Snake R. (RK 67.6) } \\
\text { LFH Dam (below dam) } \\
\text { LGO Dam } \quad \text { (RK 100.1) } \\
\text { Snake R. } \\
\text { Near LFH (not recovered) }\end{array}$ \\
\hline 01 & 21 & $\begin{array}{l}10 / 8 \\
10 / 15 \\
10 / 21\end{array}$ & $\begin{array}{l}\text { Tagged CHAR } \\
\text { Snake R. (RK 57.1) } \\
\text { IHR Dam forebay }\end{array}$ \\
\hline 01 & 22 & $\begin{array}{l}9 / 27 \\
10 / 6-9 \\
10 / 21-26 \\
10 / 28 \\
11 / 9-12 / 3 \\
12 / 9\end{array}$ & $\begin{array}{ll}\text { Tagged HPK } \\
\text { IHR Dam } & \text { (below dam) } \\
\text { Col. R. } & \text { (RK 527.8-569.6) } \\
\text { IHR Dam } & \text { (below dam) } \\
\text { Col. R. } & \text { (RK 623.8-633) } \\
\text { Col. R. } & \text { (RK 605.6) }\end{array}$ \\
\hline 01 & 23 & $\begin{array}{l}9 / 26 \\
10 / 1-2 \\
10 / 4 \\
10 / 6-7 \\
10 / 8-9 \\
10 / 9 \\
10 / 10 \\
10 / 11 \\
10 / 15 \\
10 / 15 \\
10 / 17-22 \\
10 / 25-26 \\
10 / 30-11 / 17\end{array}$ & $\begin{array}{l}\text { Tagged HPK } \\
\text { IHR Dam } \\
\text { LMO Dam } \\
\text { LGO Dam (below dam) } \\
\text { LGR Dam (bR } \\
\text { LGR adult trap c } \\
\text { LGR Dam } \\
\text { Snake R. (RK 210.3) } \\
\text { LGR Dam (fall back) } \\
\text { Snake R. (RK 166.9) } \\
\text { LGR Dam (below dam) } \\
\text { LGO Dam (fall back) } \\
\text { LFH in steelhead pond d }\end{array}$ \\
\hline 01 & 24 & $\begin{array}{l}10 / 19 \\
10 / 20-11 / 1 \\
11 / 3 \\
11 / 4-5 \\
11 / 5 \\
11 / 13-20 \\
12 / 1-14\end{array}$ & $\begin{array}{l}\text { Tagged HPK } \\
\text { IHR Dam } \\
\text { LMO Dam } \\
\text { LGO Dam } \quad(\text { below dam) } \\
\text { Snake R. (RK 100.1) } \\
\text { Tuc. R. (RK O-2.7) } \\
\text { Snake R. } \quad(\text { RK 100.1) }\end{array}$ \\
\hline
\end{tabular}


Appendix D, continued.

\begin{tabular}{|c|c|c|c|}
\hline Channel & Code & $\begin{array}{l}\text { Dates } \\
\text { (month/day) }\end{array}$ & Comments \\
\hline$\overline{01}$ & 26 & $\begin{array}{l}9 / 28 \\
10 / 2-4 \\
10 / 5-6 \\
10 / 6 \\
10 / 6 \\
10 / 9 \\
10 / 15 \\
10 / 19-12 / 10 \\
12 / 18\end{array}$ & $\begin{array}{l}\text { Tagged CHAR } \\
\text { (LMO Dam)-no data } \\
\text { LGO Dam } \\
\text { LGR Dam (below dam) } \\
\text { LGR adult trap c } \\
\text { LGR Dam } \\
\text { Snake R. (RK 237.1) } \\
\text { Snake R. (RK 191.5) } \\
\text { CWR R. (RK } 7.6-49.7) \\
\text { CWR R. (RK 34.5) }\end{array}$ \\
\hline 01 & 27 & $\begin{array}{l}9 / 15 \\
10 / 20-11 / 1 \\
11 / 2-3 \\
11 / 4-5 \\
11 / 6 \\
11 / 6-7 \\
11 / 8-15 \\
11 / 21-25\end{array}$ & $\begin{array}{l}\text { Tagged HPK } \\
\text { IHR Dam } \\
\text { LMO Dam } \\
\text { LGO Dam } \\
\text { LGR adult trap }{ }^{c} \\
\text { LGR Dam } \\
\text { Snake R. (RK 237.1) } \\
\text { LGR Dam (fall back) }\end{array}$ \\
\hline 01 & 28 & $\begin{array}{l}9 / 11 \\
9 / 15 \\
9 / 17-18 \\
9 / 19 \\
9 / 19 \\
9 / 20 \\
9 / 20-25 \\
10 / 1 \\
10 / 9\end{array}$ & 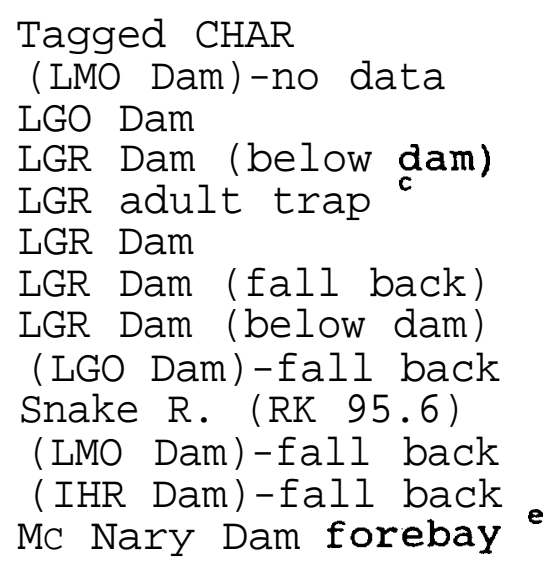 \\
\hline 01 & 29 & $\begin{array}{l}10 / 27 \\
12 / 3\end{array}$ & $\begin{array}{l}\text { Tagged HPK } \\
\text { Col.R. (RK 509.2) }\end{array}$ \\
\hline 01 & 30 & $\begin{array}{l}9 / 30 \\
10 / 1 \\
10 / 7 \\
10 / 15 \\
10 / 20-26 \\
11 / 6 \\
11 / 6 \\
11 / 8-12 \\
12 / 1 \\
12 / 23\end{array}$ & $\begin{array}{l}\text { Tagged LGR } \\
\text { LGR Dam } \\
\text { Snake R. (RK 219.1) } \\
\text { Snake R. (RK 224.6) } \\
\text { CWR R. (RK } 7.6-35) \\
\text { LGR Dam (fali back) } \\
\text { LGR adult trap c } \\
\text { LGR Dam (fall back) } \\
\text { Snake R. (RK 167.3) } \\
\text { Snake R. (RK 169.4) }\end{array}$ \\
\hline
\end{tabular}


Appendix D, continued.

\begin{tabular}{|c|c|c|c|}
\hline Channel & Code & $\begin{array}{l}\text { Dates } \\
\text { (month/day) }\end{array}$ & Comments \\
\hline$\overline{01}$ & 31 & $\begin{array}{l}9 / 12 \\
9 / 18-10 / 6 \\
10 / 14 \\
10 / 14-11 / 9\end{array}$ & $\begin{array}{l}\text { Tagged CHAR } \\
\text { (LMO Dam)-no data } \\
\text { LFH } \\
\text { Snake } \mathbf{R} \cdot(\text { RK } 100.1) \\
\text { LFH }\end{array}$ \\
\hline 01 & 31 & $\begin{array}{l}10 / 26 \\
10 / 27 \\
11 / 9\end{array}$ & $\begin{array}{l}\text { Reused radio tag HPK } \\
\text { IHR Dam (below dam) } \\
\text { Col. R. (RK 595.2) }\end{array}$ \\
\hline 01 & 32 & $\begin{array}{l}10 / 11 \\
10 / 24\end{array}$ & $\begin{array}{l}\text { Tagged HPK } \\
\text { Col. R. (RK 529) }\end{array}$ \\
\hline 01 & 33 & $\begin{array}{l}10 / 21 \\
10 / 21 \\
10 / 30 \\
11 / 3-12 \\
11 / 12 \\
12 / 1-23\end{array}$ & $\begin{array}{l}\text { Tagged LGR } \\
\text { LGR Dam } \\
\text { Snake R. (RK 237.1) } \\
\text { Gr. Ronde R. (RK 1.7-9.7) } \\
\text { Snake R. (RK 237.1) } \\
\text { LGR Dam forebay }\end{array}$ \\
\hline 01 & 34 & $\begin{array}{l}9 / 22 \\
9 / 28-10 / 2 \\
10 / 9-27 \\
10 / 28 \\
10 / 28 \\
10 / 28 \\
10 / 29 \\
10 / 30 \\
11 / 5 \\
11 / 10\end{array}$ & $\begin{array}{l}\text { Tagged CHAR } \\
\text { LMO Dam } \\
\text { LGO Dam } \\
\text { LGR Dam (below dam) } \\
\text { LGR adult trap } \\
\text { LGR Dam } \\
\text { Snake R. (RK 237.1) } \\
\text { Snake R. (RK 277.5) } \\
\text { Imnaha R. (RK 0.4) a b } \\
\text { Imnaha R. (RK 0.5) }\end{array}$ \\
\hline 01 & 35 & $\begin{array}{l}10 / 17 \\
10 / 21-26 \\
11 / 9-11 \\
11 / 17\end{array}$ & $\begin{array}{l}\text { Tagged HPK } \\
\text { Co'l. R. (RK 569.6-594.5) } \\
\text { IHR Dam in fish ladder } \\
\text { LMO Dam in }\end{array}$ \\
\hline 01 & 36 & $\begin{array}{l}9 / 13 \\
9 / 14 \\
9 / 14-11 / 10 \\
11 / 11-12 \\
11 / 13 \\
11 / 13-14 \\
11 / 19-23 \\
12 / 1 \\
12 / 11\end{array}$ & $\begin{array}{l}\text { Tagged CHAR } \\
\text { IHR Dam (fall back) } \\
\text { IHR Dam } \\
\text { LMO Dam } \\
\text { Snake R. (RK 98.3) } \\
\text { LGO Dam } \\
\text { LGR Dam (below dam) } \\
\text { Snake R. (RK 123.2) } \\
\text { Snake R. (RK 116.2) }\end{array}$ \\
\hline
\end{tabular}


Appendix D, continued.

\begin{tabular}{|c|c|c|c|}
\hline Channel & Code & $\begin{array}{l}\text { Dates } \\
\text { (month/day) }\end{array}$ & Comments \\
\hline$\overline{01}$ & 37 & $\begin{array}{l}10 / 30 \\
10 / 30-31 \\
11 / 3 \\
11 / 5 \\
11 / 7-9 \\
11 / 12 \\
11 / 13-12 / 16 \\
12 / 16-1 / 6\end{array}$ & $\begin{array}{l}\text { Tagged LGR } \\
\text { LGR Dam } \\
\text { Snake R. (RK 237.1) } \\
\text { Snake R. (RK 302.8) } \\
\text { above the Salmon R. } \\
\text { Snake R. (RK 237.1-253.6) } \\
\text { Gr. Ronde R. (RK 1) } \\
\text { Snake R. (RK 253.6-261.4) } \\
\text { Snake R. (RK 253.6) }\end{array}$ \\
\hline 01 & 38 & $\begin{array}{l}10 / 21 \\
11 / 9-12 / 15 \\
12 / 23\end{array}$ & $\begin{array}{l}\text { Tagged CHAR } \\
\text { (IHR Dam)-fall back } \\
\text { Yak. R. (RK } 46.7-48.3) \\
\text { Yak. R. (RK 47.6) }\end{array}$ \\
\hline 01 & 39 & $\begin{array}{l}9 / 19 \\
10 / 8 \\
10 / 8 \\
10 / 14-11 / 9\end{array}$ & $\begin{array}{l}\text { Tagged CHAR } \\
\text { IHR Dam (fall back) } \\
\text { IHR Dam } \\
\text { (LMO Dam)-no data } \\
\text { LFH a b }\end{array}$ \\
\hline 01 & 40 & $\begin{array}{l}9 / 21 \\
9 / 21-23 \\
9 / 26-11 / 7 \\
11 / 10 \\
11 / 14\end{array}$ & $\begin{array}{l}\text { Tagged LGR } \\
\text { LGR Dam } \\
\text { CWR R. (RK 7.6-124) } \\
\text { Snake R. (RK 210.3) } \\
\text { Snake R. (RK 206.3) }\end{array}$ \\
\hline 01 & 41 & $\begin{array}{l}10 / 2 \\
11 / 9-12 / 15 \\
12 / 23\end{array}$ & $\begin{array}{l}\text { Tagged HPK } \\
\text { Yak. R. (RK } 46.7-48.3) \\
\text { Yak. R. (RK } 47.6)\end{array}$ \\
\hline 01 & 42 & $\begin{array}{l}9 / 20 \\
9 / 26-11 / 2 \\
11 / 3 \\
11 / 20-12 / 1 \\
12 / 6\end{array}$ & $\begin{array}{l}\text { Tagged HPK } \\
\text { IHR Dam } \\
\text { LMO Dam } \\
\text { LFH } \\
\text { LGO Dam (below dam) }\end{array}$ \\
\hline 01 & 43 & $\begin{array}{l}10 / 8 \\
10 / 12 \\
10 / 14-11 / 9\end{array}$ & $\begin{array}{l}\text { Tagged CHAR } \\
\text { (LMO Dam)-no data } \\
\text { LGO Dam (below dam) } \\
\text { LFH áb }\end{array}$ \\
\hline 01 & 44 & $\begin{array}{l}10 / 28 \\
10 / 30-11 / 5 \\
11 / 6 \\
11 / 10-17\end{array}$ & $\begin{array}{l}\text { Tagged CHAR } \\
\text { LMO Dam } \\
\text { LGO Dam (below dam) } \\
\text { LFH ab }\end{array}$ \\
\hline
\end{tabular}


Appendix D, continued.

\begin{tabular}{|c|c|c|c|}
\hline Channel & Code & $\begin{array}{l}\text { Dates } \\
\text { (month/day) }\end{array}$ & Comments \\
\hline$\overline{01}$ & 45 & $\begin{array}{l}9 / 11 \\
9 / 17 \\
10 / 15 \\
12 / 3 \\
12 / 23\end{array}$ & $\begin{array}{l}\text { Tagged CHAR } \\
\text { (LMO Dam)-no data } \\
\text { LFH } \\
\text { (LMO Dam)-fall back } \\
\text { Snake R. (RK 46.2) } \\
\text { (IHR Dam)-fallback } \\
\text { Yak. R. (RK 56.3) } \\
\text { Yak. R. (RK 66) }\end{array}$ \\
\hline 01 & 46 & $\begin{array}{l}9 / 21 \\
9 / 21-10 / 4 \\
10 / 6 \\
10 / 8 \\
10 / 8 \\
10 / 10 \\
10 / 10 \\
10 / 10 \\
10 / 11-15 \\
10 / 15 \\
11 / 7 \\
11 / 8 \\
11 / 8-19\end{array}$ & $\begin{array}{l}\text { Tagged HPK } \\
\text { IHR Dam } \\
\text { LMO Dam } \\
\text { LGO Dam } \\
\text { LGR adult trap c } \\
\text { (LGR Dam) -no data } \\
\text { LGR Dam (fallback) } \\
\text { LGR adult trap } \\
\text { LGR Dam } \\
\text { Snake R. (RK 237.1) } \\
\text { Snake R. (RK 215.6) } \\
\text { LGR Dam (fallback) } \\
\text { LGR adult trap } \\
\text { LGR Dam (fallback) }\end{array}$ \\
\hline 01 & 47 & $\begin{array}{l}10 / 19 \\
10 / 26 \\
11 / 9\end{array}$ & $\begin{array}{ll}\text { Tagged } & \text { HPK } \\
\text { Col. R. } & (\mathrm{RK} \text { 627.5) } \\
\text { Col. R. } & (\text { RK 599) }\end{array}$ \\
\hline 01 & 48 & $\begin{array}{l}9 / 18 \\
10 / 14-11 / 9 \\
12 / 10\end{array}$ & $\begin{array}{l}\text { Tagged HPK } \\
\text { Col. R. } \quad(\text { RK 545-595.2) } \\
\text { Col. R. }(\text { RK 542.7) }\end{array}$ \\
\hline 01 & 49 & $\begin{array}{l}9 / 23 \\
10 / 3-21 \\
10 / 22 \\
10 / 23 \\
10 / 23 \\
10 / 30 \\
\text { unknown }\end{array}$ & $\begin{array}{l}\text { Tagged CHAR } \\
\text { (LMO Dam)-no data } \\
\text { LGO Dam } \\
\text { LGR Dam (below dam) } \\
\text { LGR adult trap } \\
\text { LGR Dam } \\
\text { Gr. Ronde R. (RK } 3.2) \\
\text { Gr. Ronde R. (RK 74.5) }\end{array}$ \\
\hline 01 & 50 & $\begin{array}{l}9 / 14 \\
9 / 14-15 \\
9 / 18 \\
9 / 27-11 / 6\end{array}$ & $\begin{array}{l}\text { Tagged HPK } \\
\text { IHR Dam (below dam) } \\
\text { Snake R. (RK 13.7) } \\
\text { IHR Dam (did not cross) }\end{array}$ \\
\hline
\end{tabular}


Appendix D, continued.

\begin{tabular}{|c|c|c|c|}
\hline Channel & Code & $\begin{array}{l}\text { Dates } \\
\text { (month/day) }\end{array}$ & Comments \\
\hline$\overline{02}$ & 01 & $\begin{array}{l}9 / 17 \\
10 / 5-14 \\
10 / 15 \\
10 / 15 \\
11 / 2\end{array}$ & $\begin{array}{l}\text { Tagged HPK } \\
\text { Col. R. (RK 596.8-597) } \\
\text { Snake R. (RK 2.6) } \\
\text { IHR Dam (below dam) } \\
\text { Priest Rapids FH a }\end{array}$ \\
\hline 02 & 03 & $\begin{array}{l}10 / 4 \\
10 / 7-11 / 1 \\
11 / 2 \\
11 / 3 \\
11 / 10 \\
11 / 17-18 \\
11 / 20-28 \\
11 / 30 \\
12 / 1-14\end{array}$ & $\begin{array}{l}\text { Tagged HPK } \\
\text { IHR Dam } \\
\text { LMO Dam } \\
\text { LFH Dam } \\
\text { LGO Dam } \\
\text { LGR Dam (below dam) } \\
\text { LGO Dam (fallback) } \\
\text { LMO Dam forebay } \\
\text { Near LFH (not recovered) }\end{array}$ \\
\hline 02 & 04 & $\begin{array}{l}10 / 12 \\
10 / 15 \\
10 / 17-23 \\
10 / 26 \\
10 / 28-11 / 2 \\
11 / 6-12 \\
11 / 14 \\
11 / 18-20 \\
12 / 1\end{array}$ & 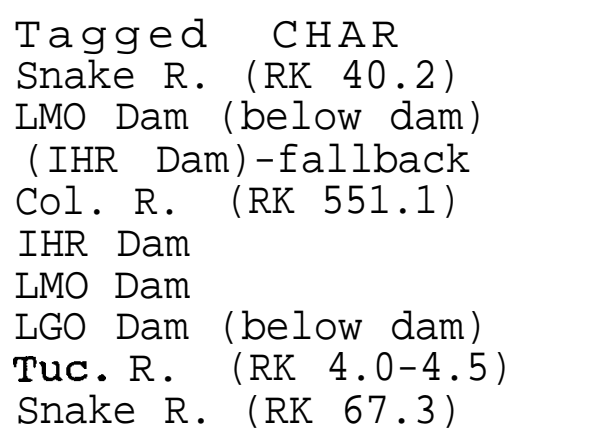 \\
\hline 02 & 05 & $\begin{array}{l}9 / 24 \\
9 / 28-10 / 5 \\
10 / 6 \\
10 / 14 \\
10 / 10-11 / 9\end{array}$ & $\begin{array}{l}\text { Tagged CHAR } \\
\text { (LMO Dam)-no data } \\
\text { LGO Dam (below dam) } \\
\text { Snake R. (RK 95.6) } \\
\text { Snake R. (RK 100.1) } \\
\text { LFH a b }\end{array}$ \\
\hline 02 & 06 & $\begin{array}{l}10 / 1 \\
10 / 5 \\
10 / 6-18 \\
10 / 19-20 \\
10 / 21 \\
10 / 26-11 / 17\end{array}$ & 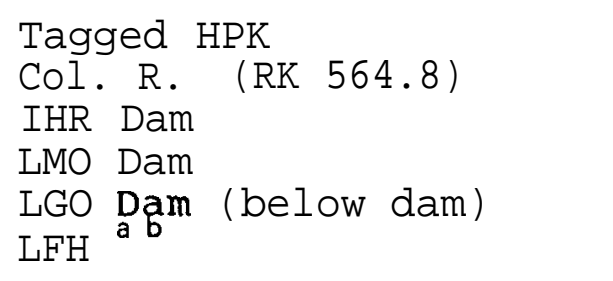 \\
\hline 02 & 07 & $\begin{array}{l}9 / 16 \\
9 / 21 \\
10 / 5-13 \\
10 / 14\end{array}$ & $\begin{array}{l}\text { Tagged HPK } \\
\text { IHR Dam (below dam) } \\
\left.\text { Col. R. (RK 602-618. }{ }^{7}\right) \\
\text { Col. R. } \quad(\text { RK 624.3) }\end{array}$ \\
\hline
\end{tabular}


Appendix D, continued.

\begin{tabular}{|c|c|c|c|}
\hline Channel & Code & $\begin{array}{l}\text { Dates } \\
\text { (month/day) }\end{array}$ & Comments \\
\hline$\overline{02}$ & 08 & $\begin{array}{l}9 / 25 \\
10 / 1 \\
10 / 6 \\
10 / 14-11 / 9\end{array}$ & $\begin{array}{l}\text { Tagged CHAR } \\
\text { (LMO Dam)-no data } \\
\text { Snake R. (RK 103.3) } \\
\text { LGO Dam (below dam) } \\
\text { LFH abm }\end{array}$ \\
\hline 02 & 09 & $\begin{array}{l}9 / 16 \\
9 / 16-18 \\
9 / 18 \\
10 / 5-11 / 6 \\
11 / 7 \\
11 / 9 \\
11 / 9 \\
12 / 3-15 \\
12 / 23\end{array}$ & 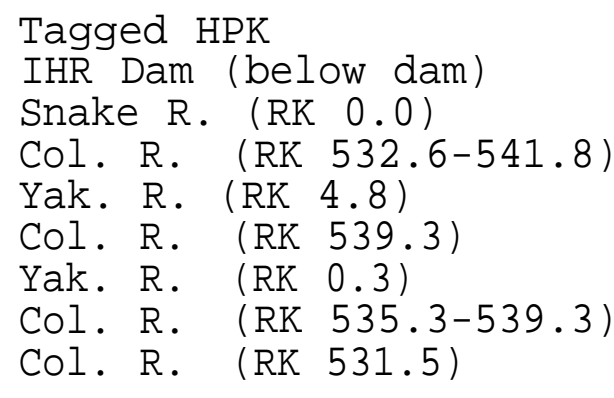 \\
\hline 02 & 10 & $\begin{array}{l}10 / 17 \\
10 / 17\end{array}$ & $\begin{array}{l}\text { Tagged HPK } \\
\text { Col. R. } \quad(\mathrm{RK} \text { 624.3) e }\end{array}$ \\
\hline 02 & 11 & $\begin{array}{l}9 / 21 \\
9 / 21-10 / 11 \\
12 / 23\end{array}$ & $\begin{array}{l}\text { Tagged HPK } \\
\text { IHR Dam (below dam) } \\
\text { Yak. R. (RK 148) }\end{array}$ \\
\hline 02 & 14 & $\begin{array}{l}9 / 15 \\
9 / 18 \\
9 / 25-26 \\
9 / 29-30 \\
10 / 2 \\
10 / 3 \\
10 / 10-12 / 10 \\
12 / 18\end{array}$ & $\begin{array}{l}\text { Tagged HPK } \\
\text { Col. R. (RK 520.3) } \\
\text { IHR Dam } \\
\text { (LMO Dam) -no data } \\
\text { LGO Dam } \\
\text { LGR adult trap c } \\
\text { LGR Dam } \\
\text { CWR R. (RK 7.6-45.9) } \\
\text { CWR R. (RK 34.4) }\end{array}$ \\
\hline 02 & 15 & $\begin{array}{l}10 / 9 \\
11 / 9-12 / 15 \\
12 / 23\end{array}$ & $\begin{array}{l}\text { Tagged CHAR } \\
\text { (IHR Dam)-fallback } \\
\text { Yak. R. (RK } 45.1-47.6) \\
\text { Yak. R. (RK 47.6) }\end{array}$ \\
\hline 02 & 16 & $\begin{array}{l}10 / 5 \\
10 / 6-11 / 3 \\
11 / 7-12 / 3 \\
12 / 13\end{array}$ & $\begin{array}{l}\text { Tagged HPK } \\
\text { IHR Dam (below dam) } \\
\text { Yak. R. (RK 16.9-47.6) } \\
\text { Yak. R. (RK 14.5) }\end{array}$ \\
\hline
\end{tabular}


Appendix D, continued.

\begin{tabular}{|c|c|c|c|}
\hline Channel & Code & $\begin{array}{l}\text { Dates } \\
\text { (month/day) }\end{array}$ & Comments \\
\hline$\overline{02}$ & 17 & $\begin{array}{l}9 / 17 \\
10 / 8-16 \\
11 / 6\end{array}$ & $\begin{array}{l}\text { Tagged HPK } \\
\text { IHR Dam (below dam) } \\
\text { Yak. R. (RK 138.4) } \\
\text { Yakima Indian Nation } \\
\text { broodstock }\end{array}$ \\
\hline 02 & 18 & $\begin{array}{l}9 / 20 \\
10 / 5 \\
10 / 22-11 / 4 \\
11 / 5-6 \\
11 / 7-10 \\
11 / 13 \\
11 / 20\end{array}$ & 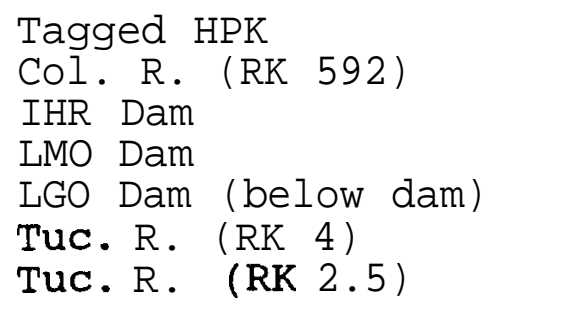 \\
\hline 02 & 19 & $\begin{array}{l}9 / 17 \\
9 / 18 \\
9 / 18 \\
12 / 23\end{array}$ & $\begin{array}{l}\text { Tagged HPK } \\
\text { IHR Dam (below dam) } \\
\text { Snake R. (RK 12.9) } \\
\text { Yak. R. (RK 146.4) }\end{array}$ \\
\hline 02 & 20 & $\begin{array}{l}10 / 7 \\
10 / 9 \\
10 / 15 \\
10 / 18-12 / 10 \\
12 / 18\end{array}$ & $\begin{array}{l}\text { Tagged LGR } \\
\text { LGR Dam } \\
\text { Snake R. (RK 204.7) } \\
\text { CWR R. (RK } 0.6-7.4) \\
\text { CWR R. (RK } 3.8)\end{array}$ \\
\hline 02 & 21 & $\begin{array}{l}10 / 18 \\
10 / 23 \\
10 / 26-28 \\
11 / 9 \\
12 / 23\end{array}$ & $\begin{array}{ll}\text { Tagged } & \text { CHAR } \\
\text { LMO Dam } & \text { (below dam) } \\
\text { IHR Dam } & (\text { fallback) } \\
\text { Yak. R. } & \text { (RK 20.9) } \\
\text { Yak. R. } & \text { (RK 25.4) }\end{array}$ \\
\hline 02 & 22 & $\begin{array}{l}10 / 8 \\
10 / 14\end{array}$ & $\begin{array}{l}\text { Tagged CHAR } \\
\text { (IHR Dam)-fallback } \\
\text { Col. R. (RK 567.2) }\end{array}$ \\
\hline 02 & 23 & $\begin{array}{l}10 / 11 \\
10 / 15-11 / 3 \\
11 / 9-12 / 15 \\
12 / 23\end{array}$ & $\begin{array}{l}\text { Tagged HPK } \\
\text { IHR Dam (below dam) } \\
\text { Yak. R. (RK 45.1-47.6) } \\
\text { Yak. R. (RK 47.6) }\end{array}$ \\
\hline 02 & 24 & $\begin{array}{l}9 / 27 \\
10 / 2-3 \\
10 / 4 \\
10 / 6-8 \\
10 / 15-11 / 7\end{array}$ & $\begin{array}{l}\text { Tagged HPK } \\
\text { IHR Dam } \\
\text { LMO Dam } \\
\text { LGO Dam (below dam) } \\
\text { LFH ab }\end{array}$ \\
\hline
\end{tabular}


Appendix D, continued.

\begin{tabular}{|c|c|c|c|}
\hline Channel & Code & $\begin{array}{l}\text { Dates } \\
\text { (month/day) }\end{array}$ & Comments \\
\hline$\overline{02}$ & 25 & $\begin{array}{l}9 / 15 \\
9 / 21-22 \\
12 / 3-15 \\
12 / 23\end{array}$ & $\begin{array}{l}\text { Tagged HPK } \\
\text { IHR Dam (below dam) } \\
\text { Yak. R. (RK 45.1-47.6) } \\
\text { Yak. R. (RK 47.6) }\end{array}$ \\
\hline 02 & 26 & $\begin{array}{l}9 / 16 \\
9 / 18-10 / 5 \\
10 / 13-26 \\
10 / 30\end{array}$ & 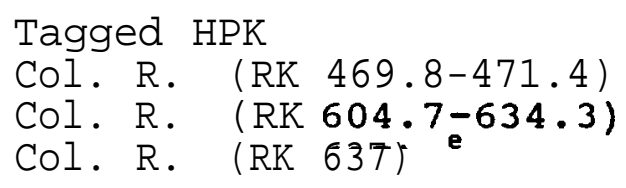 \\
\hline 02 & 27 & $\begin{array}{l}10 / 1 \\
10 / 5-12 / 10 \\
12 / 15\end{array}$ & 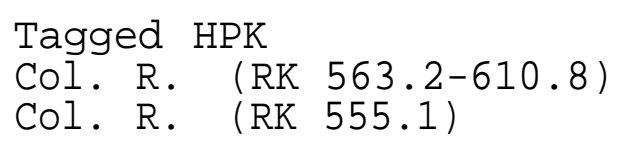 \\
\hline 02 & 28 & $\begin{array}{l}10 / 10 \\
10 / 15 \\
10 / 21 \\
12 / 3-10 \\
12 / 15-23\end{array}$ & $\begin{array}{l}\text { Tagged CHAR } \\
\text { Snake R. }(\text { RK 57.9) } \\
\text { IHR Dam } \quad(\text { fallback) } \\
\text { Col. R. } \quad(\text { RK 551.1-559.1) } \\
\text { Col. R. } \quad(\text { RK 552.7) }\end{array}$ \\
\hline 02 & 29 & $\begin{array}{l}10 / 8 \\
10 / 14-15 \\
10 / 25 \\
10 / 26-30 \\
10 / 31-11 / 2 \\
11 / 3 \\
11 / 10 \\
11 / 10 \\
11 / 11 \\
11 / 12\end{array}$ & $\begin{array}{l}\text { Tagged CHAR } \\
\text { (LMO Dam)-no data } \\
\text { LFH } \\
\text { LGO Dam (below dam) } \\
\text { LFH } \\
\text { LGO Dam (below dam) } \\
\text { LFH } \\
\text { LGO Dam } \\
\text { Snake R. (RK 123.2) } \\
\text { LGR Dam } \\
\text { LGR adult trap ch }\end{array}$ \\
\hline 02 & 30 & $\begin{array}{l}9 / 17 \\
10 / 5 \\
10 / 7 \\
10 / 11 \\
10 / 15 \\
10 / 26\end{array}$ & $\begin{array}{l}\text { Tagged HPK } \\
\text { Col. R. (RK 635.6) } \\
\text { IHR Dam } \\
\text { (LMO Dam) - no data } \\
\text { LGO Dam (below dam) } \\
\text { Snake R. (RK 68.5) } \\
\text { Snake R. (RK } 72.4)\end{array}$ \\
\hline
\end{tabular}


Appendix D, continued.

\begin{tabular}{|c|c|c|c|}
\hline Channel & Code & $\begin{array}{l}\text { Dates } \\
\text { (month/day) }\end{array}$ & Comments \\
\hline$\overline{02}$ & 31 & $\begin{array}{l}9 / 18 \\
9 / 19-26 \\
9 / 28 \\
9 / 30-10 / 1 \\
10 / 2-3 \\
10 / 3 \\
10 / 3 \\
10 / 5-8 \\
10 / 12 \\
10 / 17 \\
10 / 20-21 \\
10 / 26 \\
11 / 4 \\
11 / 5-7 \\
11 / 8-24 \\
12 / 10\end{array}$ & $\begin{array}{l}\text { Tagged HPK } \\
\text { IHR Dam } \\
\text { Snake R. (RK 66.3) } \\
\text { (LMO Dam) -no data } \\
\text { LGO Dam (below dam) } \\
\text { LGR Dam (b) } \\
\text { LGR adult trap } \\
\text { LGR Dam } \\
\text { CWR R. (RK 7.6-56.8) } \\
\text { Snake R. (RK 228.1) } \\
\text { CWR R. (RK 7.6-62.1) } \\
\text { Snake R. (RK 237.1) } \\
\text { Snake R. (RK } 178.1) \\
\text { CWR R. (RK 7.6-37.8) } \\
\text { Snake R. (RK 237.1-268) } \\
\text { CWR R. (RK 7.6-37.5) } \\
\text { CWR R. (RK 36) }\end{array}$ \\
\hline 02 & 32 & $\begin{array}{l}10 / 2 \\
10 / 5-12 / 9 \\
12 / 15\end{array}$ & $\begin{array}{ll}\text { Tagged } & \text { HPK } \\
\text { Col. R. } & (\mathrm{RK} 563.2-600.2) \\
\text { Col. R. } & (\text { RK 593.6) }\end{array}$ \\
\hline 02 & 33 & $\begin{array}{l}9 / 19 \\
9 / 20 \\
10 / 3-10 \\
10 / 11 \\
10 / 14-12 / 10 \\
12 / 18\end{array}$ & $\begin{array}{l}\text { Tagged LGR } \\
\text { LGR Dam } \\
\text { CWR R. }(\text { RK } 7.6-24.5) \\
\text { Snake R. (RK 210.6) } \\
\text { CWR R. (RK 7.6-34.5) } \\
\text { CWR R. (RK 33.9) }\end{array}$ \\
\hline 02 & 34 & $\begin{array}{l}9 / 19 \\
9 / 19 \\
10 / 1 \\
10 / 10 \\
10 / 12 \\
10 / 22-28\end{array}$ & $\begin{array}{l}\text { Tagged LGR } \\
\text { LGR Dam } \\
\text { Snake R. (RK } 190.8) \\
\text { LGR Dam (fall back) } \\
\text { LGO Dam (fall back) } \\
\text { LFH a }\end{array}$ \\
\hline 02 & 35 & $\begin{array}{l}9 / 19 \\
10 / 13-26 \\
11 / 9\end{array}$ & $\begin{array}{l}\text { Tagged CHAR } \\
\text { (IHR Dam)-fall back } \\
\text { Col. R. (Rk 600.2-610.6) } \\
\text { Col. R. (RK } 595.2\end{array}$ \\
\hline 02 & 36 & $\begin{array}{l}9 / 14 \\
9 / 14 \\
10 / 3-6\end{array}$ & $\begin{array}{l}\text { Tagged LGR } \\
\text { LGR Dam } \\
\text { CWR R. (RK 7.4) }\end{array}$ \\
\hline
\end{tabular}


Appendix D, continued.

\begin{tabular}{|c|c|c|c|}
\hline Channel & Code & $\begin{array}{l}\text { Dates } \\
\text { (month/day) }\end{array}$ & Comments \\
\hline$\overline{02}$ & 37 & $\begin{array}{l}9 / 16 \\
10 / 1-13 \\
10 / 28-29\end{array}$ & $\begin{array}{l}\text { Tagged HPK } \\
\text { Col. R. (RK } 556.7-602.6) \\
\text { IHR Dam (did not cross) }\end{array}$ \\
\hline 02 & 38 & $\begin{array}{l}9 / 20 \\
9 / 20-21 \\
10 / 1 \\
10 / 19 \\
10 / 25 \\
10 / 29-31 \\
11 / 3-17\end{array}$ & $\begin{array}{l}\text { Tagged LGR } \\
\text { LGR Dam } \\
\text { Snake R. (RK 210.6) } \\
\text { CWR R. (RK 7.6) } \\
\text { LGR Dam (fall back) } \\
\text { LGO Dam (fall back) } \\
\text { LFH ab ( }\end{array}$ \\
\hline 02 & 39 & $\begin{array}{l}9 / 14 \\
9 / 17\end{array}$ & $\begin{array}{l}\text { Tagged LGR } \\
\text { LGR Dam (in fish ladder) }\end{array}$ \\
\hline 02 & 40 & $\begin{array}{l}9 / 18 \\
9 / 19 \\
10 / 1-12 / 18 \\
1 / 20\end{array}$ & $\begin{array}{l}\text { Tagged LGR } \\
\text { LGR Dam } \\
\text { CWR R. (RK 7.6-36.4 } \\
\text { CWR R. (RK } 34^{-1.44^{\circ}} \text {. }\end{array}$ \\
\hline 02 & 41 & $\begin{array}{l}9 / 26 \\
9 / 27-10 / 28 \\
11 / 9\end{array}$ & $\begin{array}{l}\text { Tagged HPK } \\
\text { IHR Dam (below dam) } \\
\text { Yak. R. (RK 47.6) }\end{array}$ \\
\hline 02 & 42 & $\begin{array}{l}9 / 19 \\
9 / 19-21 \\
9 / 26 \\
10 / 1 \\
10 / 6-14 \\
10 / 15 \\
10 / 16-21 \\
10 / 22-11 / 21\end{array}$ & $\begin{array}{l}\text { Tagged LGR } \\
\text { LGR Dam } \\
\text { LGR Dam (fall back) } \\
\text { Snake R. (RK 142.7) } \\
\text { LGR Dam (below dam) } \\
\text { Snake R. (RK 125.5) } \\
\text { LGO Dam (fall back) } \\
\text { LFH ab (fall back }\end{array}$ \\
\hline 02 & 43 & $\begin{array}{l}9 / 23 \\
10 / 5 \\
10 / 6 \\
10 / 6 \\
10 / 8 \\
10 / 28-11 / 17\end{array}$ & $\begin{array}{l}\text { Tagged CHAR } \\
\text { (LMO Dam)-no data } \\
\text { LGO Dam } \\
\text { LGR Dam } \\
\text { LGR adult trap c } \\
\text { (LGR Dam)-flushed } \\
\text { LGO (fall back) } \\
\text { LFH a }\end{array}$ \\
\hline
\end{tabular}


Appendix D, continued.

\begin{tabular}{|c|c|c|c|}
\hline Channel & Code & $\begin{array}{l}\text { Dates } \\
\text { (month/day) }\end{array}$ & Comments \\
\hline$\overline{02}$ & 45 & $\begin{array}{l}9 / 14 \\
9 / 18 \\
9 / 19-10 / 6 \\
10 / 14 \\
10 / 15 \\
10 / 16-17 \\
10 / 18 \\
10 / 26 \\
10 / 26-28 \\
10 / 31 \\
11 / 2 \\
11 / 3 \\
11 / 10 \\
11 / 12-30 \\
12 / 10\end{array}$ & $\begin{array}{l}\text { Tagged HPK } \\
\text { Col. R. (RK 515.4) } \\
\text { IHR Dam } \\
\text { (LMO Dam) -no data } \\
\text { LGO Dam } \\
\text { Snake R. (RK 123.2) } \\
\text { LGR Dam (below dam) } \\
\text { LGO Dam (fall back) } \\
\text { LFH Dam } \\
\text { LGO Dam } \\
\text { LGR Dam (below dam) } \\
\text { LGO Dam (fall back) } \\
\text { LFH Dam } \\
\text { LMO Dam } \\
\text { LMO Dam (fall back) } \\
\text { Snake R. (RK 64.2) } \\
\text { LMO Dam (below dam) }\end{array}$ \\
\hline 02 & 47 & $\begin{array}{l}9 / 24 \\
9 / 28 \\
10 / 1 \\
10 / 5-11 / 9 \\
11 / 22\end{array}$ & $\begin{array}{l}\text { Tagged CHAR } \\
\text { LMO Dam (below dam) } \\
\text { Snake R. (RK 19.3) } \\
\text { (IHR Dam)-fall back } \\
\text { Col. R. (RK } 567.2-624 \text { ) } \\
\text { Col. R. (RK 600.2) }\end{array}$ \\
\hline 02 & 48 & $\begin{array}{l}9 / 13 \\
9 / 21 \\
9 / 22-27 \\
9 / 27 \\
9 / 28 \\
9 / 29-10 / 19 \\
10 / 23-11 / 9 \\
11 / 10-11\end{array}$ & $\begin{array}{l}\text { Tagged CHAR } \\
\text { (LMO Dam)-no data } \\
\text { LGO Dam } \\
\text { LGR Dam } \\
\text { LGR adult trap c } \\
\text { LGR Dam } \\
\text { Snake R. (RK } 237.1-271.1) \\
\text { Gr. Ronde R. }(\text { RK } 0-6.9) \\
\text { Snake R. (RK 237.1) }\end{array}$ \\
\hline 02 & 50 & $\begin{array}{l}9 / 28 \\
10 / 5 \\
10 / 21 \\
11 / 9 \\
12 / 3-15\end{array}$ & $\begin{array}{l}\text { Tagged CHAR } \\
\text { (IHR Dam)-fall back } \\
\text { Col R. (RK 603.4) } \\
\text { Snake R. }(\mathrm{RK} 2.4) \\
\text { Col. R. (Rk 600.2) } \\
\text { Col. R. (RK 576) }\end{array}$ \\
\hline
\end{tabular}


Appendix D, continued.

\begin{tabular}{|c|c|c|c|}
\hline Channel & Code & $\begin{array}{l}\text { Dates } \\
\text { (month/day) }\end{array}$ & Comments \\
\hline$\overline{03}$ & 01 & $\begin{array}{l}9 / 27 \\
9 / 27-28 \\
10 / 2-12 \\
10 / 15-16 \\
10 / 18 \\
10 / 30-11 / 3 \\
11 / 7-9 \\
11 / 18\end{array}$ & 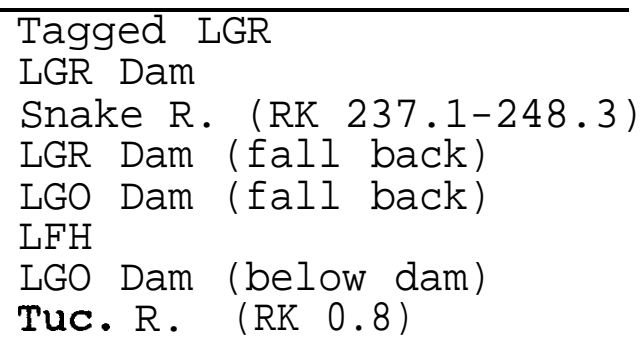 \\
\hline 03 & 02 & $\begin{array}{l}9 / 14 \\
10 / 8-11 / 7 \\
11 / 9\end{array}$ & $\begin{array}{l}\text { Tagged HPK } \\
\text { IHR Dam (below dam) } \\
\text { Yak. R. (RK 21.2) }\end{array}$ \\
\hline 03 & 04 & $\begin{array}{l}9 / 14 \\
9 / 14-30 \\
10 / 1 \\
10 / 5-13 \\
10 / 15 \\
10 / 16-12 / 16 \\
12 / 17-1 / 1\end{array}$ & 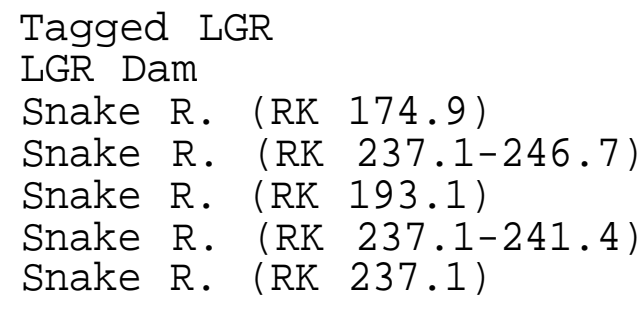 \\
\hline 03 & 05 & $\begin{array}{l}9 / 21 \\
10 / 1-4 \\
10 / 4-5 \\
10 / 6-7 \\
10 / 8 \\
10 / 9 \\
10 / 11-29 \\
11 / 4-5 \\
11 / 6-24 \\
12 / 4-16\end{array}$ & 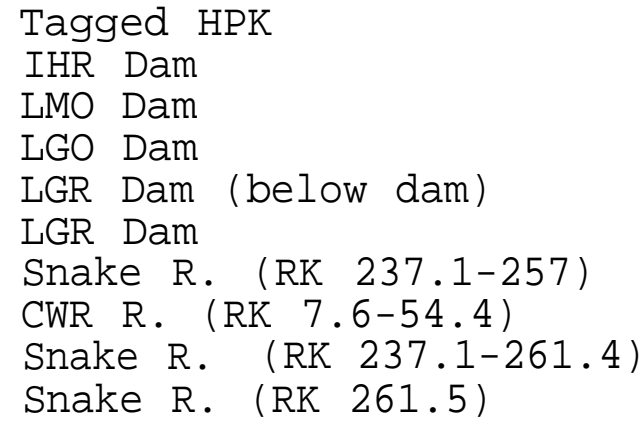 \\
\hline 03 & 06 & $\begin{array}{l}11 / 3 \\
11 / 3 \\
11 / 4-6 \\
11 / 6-24 \\
12 / 1\end{array}$ & $\begin{array}{l}\text { Tagged LGR } \\
\text { LGR Dam } \\
\text { Snake R. (RK 237.1) } \\
\text { CWR R. (RK 7.6-29) } \\
\text { CWR R. (RK 12) }\end{array}$ \\
\hline 03 & 07 & $\begin{array}{l}10 / 4 \\
10 / 5\end{array}$ & $\begin{array}{l}\text { Tagged HPK } \\
\text { Col.R. } \quad(\mathrm{RK} 564.8)\end{array}$ \\
\hline
\end{tabular}


Appendix D, continued.

\begin{tabular}{|c|c|c|c|}
\hline Channel & Code & $\begin{array}{l}\text { Dates } \\
\text { (month/day) }\end{array}$ & Comments \\
\hline$\overline{03}$ & 08 & $\begin{array}{l}9 / 20 \\
9 / 20 \\
10 / 1 \\
10 / 10 \\
11 / 9\end{array}$ & $\begin{array}{l}\text { Tagged LGR } \\
\text { LGR Dam } \\
\text { Snake R. (RK 176.5) } \\
\text { (LGR Dam)-fall back } \\
\text { LGO Juvenile Bypass k } \\
\text { facility (fall back) } \\
\text { LFH ab }\end{array}$ \\
\hline 03 & 10 & $\begin{array}{l}10 / 27 \\
10 / 27 \\
11 / 25-12 / 4\end{array}$ & $\begin{array}{l}\text { Tagged LGR } \\
\text { LGR Dam } \\
\text { Salmon R. (RK 4.8) }\end{array}$ \\
\hline 03 & 11 & $\begin{array}{l}10 / 6 \\
10 / 9 \\
10 / 15 \\
10 / 21-26\end{array}$ & $\begin{array}{l}\text { Tagged CHAR } \\
\text { (LMO Dam)-no data } \\
\text { LGO Dam (below dam) } \\
\text { (LMO Dam)-fall back } \\
\text { Snake R. (RK 48.4) } \\
\text { IHR Dam (fall back) }\end{array}$ \\
\hline 03 & 12 & $\begin{array}{l}9 / 13 \\
9 / 13 \\
9 / 13-10 / 24 \\
10 / 25 \\
10 / 26 \\
10 / 30 \\
10 / 30-31 \\
11 / 3\end{array}$ & $\begin{array}{l}\text { Tagged CHAR } \\
\text { IHR Dam (fall back) } \\
\text { IHR Dam } \\
\text { LMO Dam } \\
\text { Snake R. (RK } 86.7) \\
\text { LFH D } \\
\text { LGO Dam (below dam) } \\
\text { Near LFH (not recovered) }\end{array}$ \\
\hline 03 & 13 & $\begin{array}{l}9 / 15 \\
10 / 26-11 / 9 \\
12 / 10\end{array}$ & $\begin{array}{l}\text { Tagged HPK } \\
\text { Col. R. (RK 605.9-633.3) } \\
\text { Col. R. (RK 535.3) }\end{array}$ \\
\hline 03 & 14 & $\begin{array}{l}9 / 19 \\
9 / 24 \\
9 / 25-26 \\
9 / 27 \\
9 / 28 \\
9 / 30 \\
10 / 11 \\
10 / 15 \\
10 / 17-23 \\
10 / 26-31 \\
11 / 30-12 / 11\end{array}$ & $\begin{array}{l}\text { Tagged CHAR } \\
\text { (LMO Dam)-no data } \\
\text { LGO Dam } \\
\text { LGR Dam (below dam) } \\
\text { LGR adult trap c } \\
\text { LGR Dam } \\
\text { Snake R. (RK 237.1) } \\
\text { LGR Dam (fall back) } \\
\text { Snake R. (RK 133.5) } \\
\text { LGR Dam (below dam) } \\
\text { LGO Dam (fall back) } \\
\text { LMO Dam forebay }\end{array}$ \\
\hline
\end{tabular}


Appendix D, continued.

\begin{tabular}{|c|c|c|c|}
\hline Channel & Code & $\begin{array}{l}\text { Dates } \\
\text { (month/day) }\end{array}$ & Comments \\
\hline$\overline{03}$ & 15 & $\begin{array}{l}9 / 23 \\
9 / 24 \\
9 / 24-10 / 7 \\
10 / 15 \\
10 / 16 \\
10 / 21 \\
10 / 26 \\
11 / 9-12 / 3 \\
12 / 15\end{array}$ & 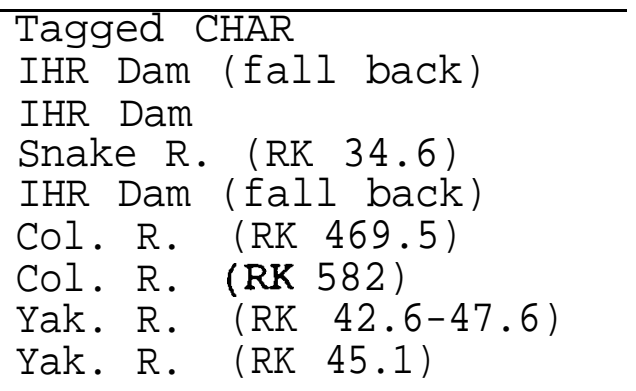 \\
\hline 03 & 16 & $\begin{array}{l}9 / 20 \\
11 / 7-12 / 3 \\
12 / 15\end{array}$ & 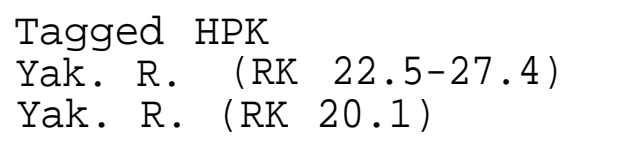 \\
\hline 03 & 17 & $\begin{array}{l}9 / 13 \\
9 / 17 \\
9 / 18-19 \\
9 / 19 \\
9 / 19 \\
10 / 30-11 / 16 \\
12 / 16\end{array}$ & $\begin{array}{l}\text { Tagged CHAR } \\
\text { (LMO Dam)-no data } \\
\text { LGO Dam } \\
\text { LGR Dam (below dam) } \\
\text { LGR adult trap c } \\
\text { LGR Dam } \\
\text { Gr. Ronde R. (RK 6.9-8.1) } \\
\text { Gr. Ronde R. (RK 6.1) }\end{array}$ \\
\hline 03 & 18 & $\begin{array}{l}10 / 30 \\
10 / 31 \\
11 / 2 \\
11 / 4 \\
11 / 4 \\
11 / 4-5 \\
11 / 6-24 \\
12 / 18\end{array}$ & $\begin{array}{l}\text { Tagged CHAR } \\
\text { LMO Dam } \\
\text { LGO Dam } \\
\text { LGR Dam (below dam) } \\
\text { LGR adult trap c } \\
\text { LGR Dam } \\
\text { CWR R. (RK 7.6-64) } \\
\text { CWR R. (RK 63.2) }\end{array}$ \\
\hline 03 & 19 & $\begin{array}{l}10 / 1 \\
10 / 31 \\
11 / 7-12 / 15 \\
11 / 23\end{array}$ & $\begin{array}{l}\text { Tagged HPK } \\
\text { IHR Dam (below dam) } \\
\text { Yak. R. (RK 45.1-48.3) } \\
\text { Yak. R. (RK 47.6) }\end{array}$ \\
\hline
\end{tabular}


Appendix D, continued.

\begin{tabular}{|c|c|c|c|}
\hline Channel & Code & $\begin{array}{l}\text { Dates } \\
\text { (month/day) }\end{array}$ & Comments \\
\hline$\overline{03}$ & 20 & $\begin{array}{l}9 / 22 \\
9 / 25 \\
9 / 27-28 \\
9 / 29 \\
9 / 29 \\
10 / 1-15 \\
10 / 17 \\
10 / 18-23 \\
10 / 26 \\
10 / 28 \\
10 / 30-11 / 3\end{array}$ & $\begin{array}{l}\text { Tagged CHAR } \\
\text { (LMO Dam)-no data } \\
\text { LGO Dam (below dam) } \\
\text { LGR Dam cR } \\
\text { LGR adult trap } \\
\text { LGR Dam } \\
\text { Snake R. (RK 187.6-209.2) } \\
\text { LGR Dam (fall back) } \\
\text { LGO Dam (fall back) } \\
\text { (LMO Dam)-fall back } \\
\text { Snake R. (RK 41.8) } \\
\text { LMO Dam } \\
\text { LFH ab }\end{array}$ \\
\hline
\end{tabular}

Recovered fish.

b spawned fish.

c Recaptured fish.

d Recaptured fish in steelhead ponds at LFH, removed the radio and returned fish to river.

e sport fishery recovery.

Fish found dead, possible tagging mortality.

9 Fish found dead, possibly spawned.

h Radio recovered later in trap so there is no tracking data from this fish after it was recaptured.

i Branded, un-clipped stray fall chinook spawned at LFH with other un-clipped fall chinook. No CWT because this fish was not adipose clipped. The brand read (RDU-1) at LGR adult trap indicating this fish was in the Bonneville Survival Study (1990 release at Spring Creek FH) .

j Fish possibly flushed out of the ladder to below the dam after being caught in the adult trap, prior to crossing LGR Dam. There was no data from the site at the top of the fish ladder to indicate this fish passed the dam. This fish could have been recaptured anytime before 6:00 pm. The adult trap was flushed at 4:45 pm and the fish was located below the dam at 6:42 pm. We believe this fish was flushed below LGR Dam.

k Recovered only radio transmitter. 


\section{APPENDIX E}

Data for fall chinook salmon radio tagged and released at Lower Granite Dam (RK 172.8), 1992.

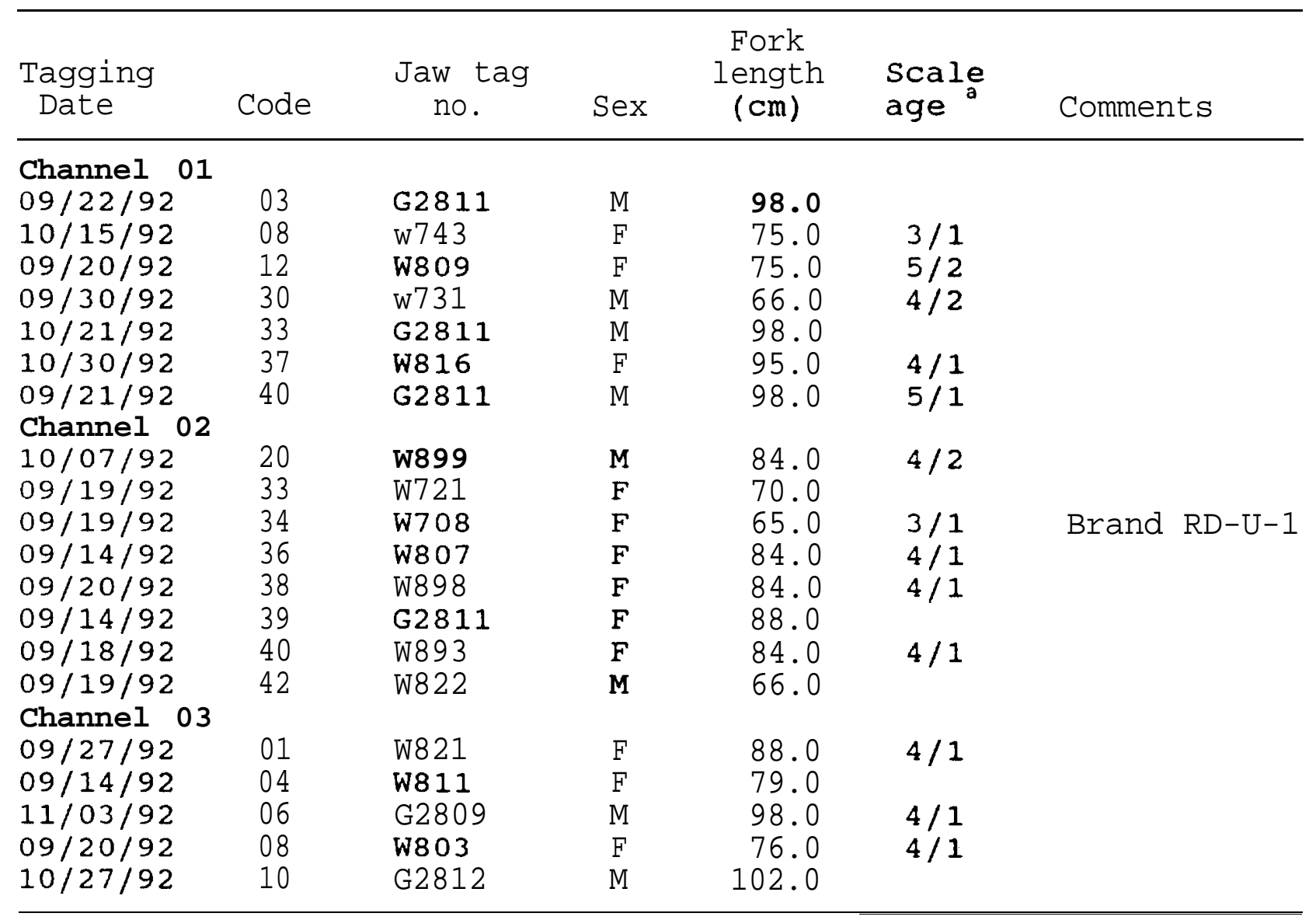

a Total age/years in fresh water. 


\section{CHAPTER TWO}

STOCK IDENTIFICATION OF SNAKE RIVER FALL CHINOOK SALMON

by

H. L. Blankenship

L. Lavoy

C. Knudsen

A. Marshall

D. Thompson

J. Sneva

Washington Department of Fisheries

Planning, Research, and Harvest Management

Olympia, Washington 98504-315 1

December 1993 


\section{ACKNOWLEDGEMENTS}

This project was funded by Bonneville Power Administration (BPA). Deborah Watkins was project manager for BPA and provided valuable administrative assistance with contracts and review of the annual report. The project could not have been accomplished without the coordinated professional assistance from Billy Connor, Aaron Garcia, Howard Burge, and Dennis Rondorf (United States Fish and Wildlife Service); Phil Groves (Idaho Power Company); Billy Arnsberg (Nez Perce Tribe); Jerry Harmon, Neil Paasch, Ken Thomas, and Ken McIntyre (National Marine Fisheries Service);

Charles Morrill (Washington Department of Wildlife); and Todd Kleist and the Lower Granite Dam fish counters. 


\section{LIST OF TABLES}

Table 1. Stock composition of fall chinook salmon counted to Lower Granite Dam

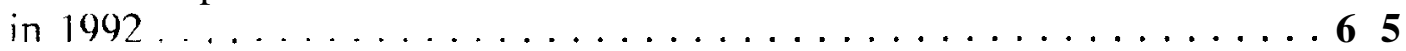

Table 2. Stock composition of fall chinook salmon escapement past Lower Ganite Dam . . . . . . . . . . . . . . . . . . . . . . . 65

Table 3. Stock composition of fall chinook salmon trucked from Lower Granite Dam to Lyons Ferry Hatchery in $1992 \ldots \ldots$. . . . . . . . . . . . . 65

Table 4. Stock composition of fall chinook salmon at Lower Granite Dam during $1990-1992 \ldots \ldots \ldots \ldots \ldots$. . . . . . . . . . . . . . . . 66

Table 5. Data from 44 fall chinook salmon carcasses collected in the Snake River

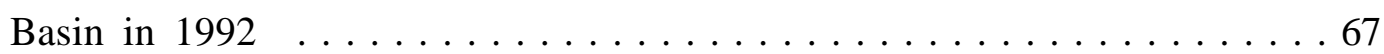

Table 6. The estimated percentage of Lyon's Ferry and mid-Columbia fall chinook salmon in the Snake River adult sample $(n=42) \ldots \ldots \ldots 69$

Table 7. The a posteriori probability values for membership to two baseline stocks of individual recoveries are given based on genetic data. Probability values outside of the 0.3 to 0.7 are highlighted and are somewhat dependable as indicators of stock origin $\ldots \ldots \ldots \ldots \ldots \ldots \ldots$

\section{LIST OF FIGURES}

Figure 1. Analysis of genetic distance among chinook stocks from the Upper Columbia and Snake Rivers. Dendrogram was constructed using 30 loci and unweighted pair group method with Cavalli-Sforza \& Edwards (1967) chord distance . . . . . . . . . . . . . . . . . . 71 


\title{
CHAPTER 2
}

\section{STOCK IDENTIFICATION OF SNAKE RIVER FALL CHINOOK SALMON}

\author{
Prepared by \\ H. Lee Blankenship \\ Larrie LaVoy \\ Curtis Knudsen \\ Anne Marshall \\ Dan Thompson \\ John Sneva
}

\begin{abstract}
This chapter describes the effort and results of the second year (of a threeyear study) to determine the amount of hatchery straying, stock composition and genetic profile of returning fall chinook salmon (Oncorynchus tshawytscha) and their offspring to the Snake River above Lower Granite Dam. Stock identification techniques included use of coded-wire tags, scale analysis, otolith analysis, and starch-gel electrophoresis for genetic analysis. Genetic and scale analysis provided evidence that there is probably not a spatial difference in spawning area between hatchery strays and native adult fall chinook salmon. Genetic analysis also indicated significant influence from mid-Columbia River chinook salmon stocks.
\end{abstract}

\section{STUDY AREA}

Intensive spawning ground surveys for collection of spawned adult salmon carcasses were conducted throughout the spawning area above Lower Granite Dam (LGR). This included the Snake River to Hells Canyon Dam as well as portions of the Cleat-water, Grande Ronde, Salmon, and Imnaha rivers. Juveniles sampled for electrophoresis were collected at LGR. The USFWS previously trapped and tagged these juveniles with passive integrated transponder (PIT) tags between the confluence of the Salmon River and the upper portion of Lower Granite pool.

\section{METHODS}

To accomplish the work described below, permission had to be obtained from National Marine Fisheries Service (NMFS) through a Section 10 Application of the Endangered Species Act. Although NMFS issued a permit to do the work, they added a request to collect all coded-wire tagged (CWT) adult fall chinook passing LGR and return these fish to Lyons Ferry Hatchery (LFH) for spawning and stock identification. Prior to 1992 only a portion of adults with CWTs were collected to determine stock identification and stray rates. Marked and unmarked chinook salmon adults at LGR were enumerated by Washington Department of Wildlife (WDW) personnel who were also counting and observing steelhead. 
Fall chinook salmon passing LGR in 1992 were counted throughout the migration. At LGR it is also possible to count nearly all fish with a CWT because the upstream fish passage system allows those fish possessing a CWT to be detected and trapped separately. Detection and trapping is not 100 percent efficient, hut efficiency is high. In 1992 NMFS requested that all fall chinook salmon with CWTs be removed from the population migrating past LGR and transported to LFH. They felt that by excluding as many hatchery origin chinook salmon as possible they could reduce the chance of compromising the genetic integrity of the natural run. These fish were jaw tagged prior to being transported to LFH and held along with fall chinook salmon collected at Ice Harbor Dam (IHR).

On-site recovery of jaw tags and CWTs occurred during weekly spawnings at LFH from 20 October to 8 December 1992. Additional samples were collected from hatchery pond mortalities. On spawning days CWTs were used to determine stock origin. Gametes from LFH origin CWT chinook (other than 1989 brood) were spawned separate from unknown and stray origin fish. It had previously been decided that 1989 brood LFH fish were genetically contaminated and should not be used as broodstock. All 1989 brood LFH chinook juveniles were tagged prior to release. Scales were collected on approximately 20 percent of the marked chinook and on 50 percent of the unmarked fish.

Except for 1989 brood LFH origin chinook, stock composition was estimated by expanding the readable tags by their respective juvenile mark rates and then by an adipose mark collection rate. For 1989 brood LFH, contribution was estimated from expanding CWT chinook salmon by the marked fish trap efficiency rate and by a juvenile tag shed rate. All chinook processed at the hatchery were examined for adipose clips (100\% sampling rate). The collection rate of dam-trapped fish was derived from the number of adipose clipped chinook salmon retained divided by an estimate of the total marks passing LGR as measured by fish counters at the viewing window.

Spawning ground observations to verify redds observed in aerial flights and sampling of spawned adult carcasses above LGR was done in cooperation with USFWS and IPC. This work was done in conjunction with the USFWS research on identifying and describing spawning habitat. Coordination occurred to avoid unnecessary and multiple visual contacts or "harassment." Spawned adults (dead or moribund) were collected with hook-and-line snagging gear. Salmon were collected on the spawning grounds by personnel very experienced with this collection method. Surveys were conducted throughout the spawning area in order to determine if an isolated area (e.g., above the confluence of Salmon River) might contain only wild chinook salmon, as opposed to a mix of hatchery strays and wild fish.

Carcasses were measured (postorbital to hypural plate) and examined for CWTs, radio telemetry tags, and other identifying characteristics such as fin marks. Tissue samples (eye, heart, liver, and muscle) were taken for later genetic analysis. Scales and otoliths 
were also collected.

To further develop a genetic baseline from the natural run of fall chinook salmon which spawned above LGR, we collected PIT tagged juveniles as they migrated downstream at LGR from June through August. These juveniles were captured above the LGR pool and PIT tagged by USFWS prior to, or at the start, of their migration.

\section{RESULTS AND DISCUSSION}

The final count of fall chinook salmon at LGR during the fall of 1992 was 855 adults ( $>22$ inches total length) and 102 jacks (12-22 inches). Composition of the adult run was 306 hatchery origin and 549 natural origin fall chinook salmon (Table 1). Lyons Ferry Hatchery comprised $98 \%$ of the estimated hatchery portion. Jacks numbered 31 hatchery and 71 natural origin chinook salmon. Adult escapement passing LGR included 549 naturally produced chinook salmon and 119 hatchery origin fish (Table 2). Jack spawning escapement consisted of 9 hatchery and 71 natural fish. A total of 209 fall chinook salmon collected at LGR were analyzed for stock composition at LFH in 1992 (Table 3).

Snake River returns of fall chinook salmon improved in 1992 from 1990 and 1991 as measured at LGR (Table 4). However, the jack count was a record low in 1992. The estimate of natural stock returning to LGR increased in 1992 to 549 adults from a low of 78 adults in 1990 (Cooney 1991) and 318 in 1991 (TAC 1992) using similar estimating methods. The method used by WDF, and accepted by NMFS, in previous years to estimate the number of wild fish passing LGR, has been to expand the sample of CWTs recovered from adults passing LGR to the total number of CWT fish passing LGR, and to expand by the tagged/untagged ratio for each CWT. The total number of fish represented by CWTs is subtracted from the total number of fish passing LGR. The remaining number of fish are then assumed to be wild fish. These estimates should be considered approximations because of the low numbers of CWT recoveries and the presence of unmarked hatchery fish in the population (especially in 1990-91). No other method exists at this time. The primary assumptions associated with these estimates are that all stray groups are represented by CWTs, the tagged fish are representative of their untagged counterparts, and that the tagged/untagged ratios reported are correct and few unmarked hatchery fish exist.

Forty-four carcasses were sampled on the spawning grounds above LGR in 1992 (Table 5). As expected, there were no CWT recoveries. A method of determining a "hatchery" versus "wild" fish has not yet been identified with salmon otoliths unless thermal marks were purposely applied to the hatchery fish. The otoliths from the carcasses will be archived for further analysis should this method become useful in the future.

Scales from adult fish were classified as age 0 or age 1 migrants. Age 1 or yearling migrants are assumed to be hatchery fish since wild fall chinook salmon are believed to migrate as 0s (at least, no evidence suggests yearling migration from mid-Columbia or Snake fall stocks). In 1992, only five of 21 fish were collected above the confluence of the Salmon River (River km. 301). Of these five, the one fish (label \# 92FF-60) 
Table 1. Stock composition of fall chinook salmon counted to Lower Granite Dam in 1992.

\begin{tabular}{|c|c|c|}
\hline TO LOWER GRANITE DAM: & $\begin{array}{c}\text { Adult } \\
(>\mathbf{2 2} \text { inches TL) }\end{array}$ & $\begin{array}{c}\text { Jack } \\
(12-22 \text { inches TL })\end{array}$ \\
\hline Total Dam Count & 855 & 102 \\
\hline Natural & 549 & 71 \\
\hline Lyons Ferry H. non-1989 brood & 139 & 11 \\
\hline Lyons Ferry H. 1989 brood & 135 & 9 \\
\hline Umatilla & 29 & 5 \\
\hline Bonneville Bypass study & 2 & 0 \\
\hline Other & 1 & 6 \\
\hline
\end{tabular}

Table 2. Stock composition of fall chinook salmon escapement past Lower Granite Dam in 1992.

\begin{tabular}{||c|c|c||}
\hline \hline ESCAPEMENT PAST LOWER GRANITE DAM: & $\begin{array}{c}\text { Adult } \\
\text { inches TL })\end{array}$ & $\begin{array}{c}\text { Jack } \\
\text { inches }\end{array}$ TL $)$ \\
\hline Total Escapement \# & 668 & 80 \\
\hline Natural & 549 & 71 \\
\hline Lyons Ferry H. non-1989 brood & 90 & 1 \\
\hline Lyons Ferry H. 1989 brood & 10 & 1 \\
\hline Umatilla & 19 & 0 \\
\hline Bonneville Bypass Study & 0 & 5 \\
\hline \hline
\end{tabular}

Table 3. Stock composition of fall chinook salmon trucked from Lower Granite Dam to Lyons Ferry Hatchery in 1992.

\begin{tabular}{||c|c|c||}
\hline TO LYONS FERRY HATCHERY: & $\begin{array}{c}\text { Adult } \\
\text { inches TL })\end{array}$ & $\begin{array}{c}\text { Jack } \\
\text { inches }\end{array}$ \\
\hline Total Transported & 187 & 22 \\
\hline Lyons Ferry H. non-1989 brood & 49 & 9 \\
\hline Lyons Ferry H. 1989 brood & 125 & 8 \\
\hline Umatilla & 10 & 4 \\
\hline Bonneville Bypass Study & 2 & 1 \\
\hline Other & 1 & 0 \\
\hline \hline
\end{tabular}


Table 4. Stock composition of fall chinook at Lower Granite Dam during 1990-92.

1990

1991

1992

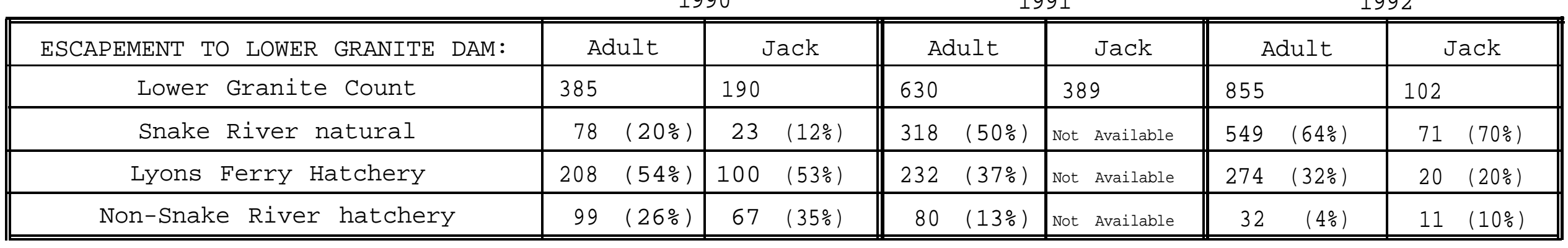

\begin{tabular}{|c|c|c|c|c|c|c|}
\hline & \multicolumn{2}{|c|}{$\underline{1990}$} & \multicolumn{2}{|c|}{1991} & \multicolumn{2}{|c|}{$\underline{1992}$} \\
\hline ESCAPEMENT PAST LOWER GRANITE DAM & Adult & Jack & Adult & Jack & Adult & Jack \\
\hline Dam Count & 385 & 190 & 630 & 389 & 855 & 102 \\
\hline Trucked to Lyons Ferry H. & -50 & -89 & -40 & -19 & -187 & -22 \\
\hline Escapement $=$ & 335 & 101 & 590 & 370 & 668 & 80 \\
\hline Natural & 78 & 23 & 318 & Not Available & 549 & 71 \\
\hline Lyons Ferry Hatchery & 174 & 47 & 202 & Not Available & 100 & 3 \\
\hline Non-Snake River hatchery & 83 & 31 & 70 & Not Available & 19 & 6 \\
\hline
\end{tabular}


Table 5. Data from 44 fall chinook salmon carcasses

collected in the Snake River Basin in 1992

\begin{tabular}{|c|c|c|c|c|c|c|c|}
\hline Date & Location & $\begin{array}{l}\text { River } \\
\mathrm{km} .\end{array}$ & $\begin{array}{l}\text { Post-Orbital to } \\
\text { Hypural (cm) }\end{array}$ & Sex & Age * & Identifying Characteristics & Labol \# \\
\hline 11109 & Gr.Ronde & & 75 & $F$ & $4 \backslash 1$ & None & $92 F F-1$ \\
\hline $11 \backslash 10$ & Snake & 311 & 75 & $F$ & $4 \backslash 1$ & None & $92 F F-2$ \\
\hline 11110 & Imnaha & & 66 & $F$ & $4 \backslash 1$ & None & $92 F F-3$ \\
\hline $11 \backslash 10$ & Imnaha & & 71 & $F$ & $4 \backslash 1$ & Radio Tag & $92 F F_{-4}$ \\
\hline 11116 & Gr.Ronde & & 76 & $F$ & $5 \backslash 1$ & None & $92 F F-5$ \\
\hline $11 \backslash 16$ & Gr.Ronde & & 76 & $F$ & $5 \backslash 1$ & None & $92 F F-6$ \\
\hline 11116 & Snake & 245 & 57 & $F$ & $3 \backslash 1$ & None & $92 F F=7$ \\
\hline $11 \backslash 16$ & Snake & 245 & 71 & $F$ & $4 \backslash 1$ & None & $92 F F-8$ \\
\hline 11119 & Dworshak & & 56 & $M$ & 311 & None & 92FF-9 \\
\hline 11119 & Snake & 261 & 52 & $\mathrm{~F}$ & $4 \backslash 1$ & None & $92 F F-10$ \\
\hline $11 \backslash 19$ & Snake & 259 & 71 & $M$ & $4 ! 1$ & None & $92 \mathrm{FF}-11$ \\
\hline $11 \backslash 19$ & Snake & 245 & 69 & F & $4 \backslash 1$ & None & $92 F F-12$ \\
\hline 11119 & Snake & 245 & 69 & $F$ & $4 \backslash 1$ & None & $92 F F-13$ \\
\hline $11 \backslash 19$ & Snake & 261 & 62 & $M$ & $3 \backslash 1$ & None & $92 F F-14$ \\
\hline $11 \backslash 19$ & Snake & 261 & 76 & $F$ & $4 \backslash 1$ & None & $92 \mathrm{FF}-15$ \\
\hline 11120 & Snake & 258 & 80 & $M$ & 511 & None & $92 \mathrm{FF}-16$ \\
\hline 11120 & Snake & 320 & 60 & $F$ & $4 \backslash 1$ & None & $92 F F=17$ \\
\hline 11120 & Dworshak & & 50 & $M$ & $3 ! 1$ & None & $92 F F-41$ \\
\hline $11 \backslash 20$ & Dworshak & & 72 & $F$ & $4 ! 1$ & None & $92 F F-42$ \\
\hline 11120 & Dworshak & & 56 & $M$ & 411 & None & $92 F F-43$ \\
\hline $11 \backslash 20$ & Dworshak & & 52 & $M$ & 412 & Yearling Out-Migrant & $92 F F-44$ \\
\hline $11 \backslash 20$ & Dworshak & & 60 & $M$ & $3\lfloor 1$ & None & $92 F F-45$ \\
\hline 11120 & Dworshak & & 58 & $M$ & $3 \backslash 1$ & None & $92 F F-46$ \\
\hline 11120 & Dworshak & & 68 & $F$ & $4 \backslash 1$ & None & $92 F F-47$ \\
\hline $11 \backslash 20$ & Dworshak & & 55 & $M$ & $3 \backslash 1$ & None & $92 F F-48$ \\
\hline $11 \backslash 23$ & Clearwater & & 87 & $M$ & 511 & None & $92 F F-21$ \\
\hline 11123 & Clearwater & & 64 & $F$ & $4 \backslash 1$ & None & $92 F F-22$ \\
\hline $11 \backslash 23$ & Clearwater & & 72 & $F$ & 512 & Yearling Out-Migrant & 92 FF-23 \\
\hline 11123 & Clearwater & & 73 & $F$ & $4 \backslash 1$ & None & $92 F F-24$ \\
\hline 11124 & Snake & 245 & 72 & $F$ & 411 & None & $92 F F-25$ \\
\hline $11 \backslash 24$ & Snake & 245 & 57 & $F$ & 412 & Yearling Out-Migrant & $92 F F-31$ \\
\hline 11124 & Snake & 245 & 53 & $M$ & $3 \backslash 1$ & None & $92 F F-32$ \\
\hline $11 \backslash 24$ & Clearwater & & 71 & $F$ & $4 \backslash 1$ & Scales Only & \\
\hline $11 \backslash 27$ & Snake & 245 & 61 & $\mathbf{F}$ & 512 & Yearling Out-Migrant & $92 F F-56$ \\
\hline 11127 & Snake & 245 & 57 & $M$ & $3 \backslash 1$ & None & $92 F F-57$ \\
\hline 12101 & Snake & 245 & 76 & $F$ & 511 & None & $92 F F-58$ \\
\hline 12101 & Snake & 245 & 57 & $F$ & $3 \backslash 1$ & None & 92FF-59 \\
\hline 12102 & Snake & 332 & 54 & $F$ & 412 & Yearling Out-Migrant & $92 F F-60$ \\
\hline $12 \backslash 04$ & Cleamater & & $71 \mathrm{~F}$ & & 441 & None & $92 F F-61$ \\
\hline 12104 & Clear-water & & 73 & $\mathbf{F}$ & $4 \backslash 1$ & None & $92 F F-62$ \\
\hline $12 ! n 4$ & Clearwater & & 69 & $\mathbf{F}$ & $5 \backslash 1$ & Tone & $92 F_{-63}$ \\
\hline 12104 & I clearrwater & & 59 & IF & T.- & (None & |92FF-81 \\
\hline $12 \backslash 04$ & Clearwater & 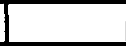 & 68 & IF & 4\11 & None & $92 F F-82$ \\
\hline 01120 & Clearwater & & 76 & 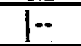 & $14 \backslash 1$ & Radio Tag \Scales Only & \\
\hline
\end{tabular}

* Age is given for age at return and age at ocean entrance (e.g. 4/2 denotes as $\mathbf{4}$ years adult return that migrated to the ocean as a yearling or during its second year of life). 
collected furthest upstream (River $\mathrm{km} \mathrm{332)}$ of all 21 recoveries in the mainstem Snake River, was a spawned female, which migrated as a yearling. This is not conclusive evidence that it is a hatchery fish, but it is highly probable. If it is a hatchery fish, then rhe theory that a spatial separation exists between wild fish and hatchery fish is questionable.

Genetic identification is another potential technique for characterizing fish not carrying a CWT. Electrophoresis has been used successfully to estimate stock composition of mixed stock groups of chinook salmon using maximum likelihood estimation (MLE) techniques (Marshall et al.). This analysis separates groups of fish as opposed to individual fish. We recently developed a way to analyze individual fish with a relatively high degree of accuracy if the genetic baselines are not too similar. This technique takes the genotypes of the individual and converts them to metric scores and uses linear discriminate analysis to classify individuals of unknown origin to the baseline group they most closely resemble. This technique was used to analyze the allele frequency data obtained from the tissues of 42 carcasses, which were sampled above LGR. Baseline group populations were from LFH and mid-Columbia River.

The 42 adult salmon from the Snake River were analyzed both, as a mixture sample, and as a collection of individual fish. Estimates of the proportion of Snake (LFH) and midColumbia fall-run fish in the adult sampler were made by both methods. In addition, the a posteriori probability of group membership was calculated for each individual fish in the Snake River sample. That is, the probability that a given fish was a member of either the LFH or mid-Columbia River group was calculated on the linear discriminant score for each fish.

A two-stock linear discriminant analysis model resulted in a classification accuracy of 70 percent for the LFH group and 65 percent for the mid-Columbia River. Thus, an average of 68 percent of the baseline fish were correctly classified. A subset of the 22 variables were used in the model. Using the BMDP 7M software (Brown et al. 1983), eight variables were selected for inclusion in the classification function based on their relatively high between-group differences in mean values. The actual estimation of the proportions of each group in the mixed-group sample was done using a program written by Russel Millar while at Fisheries Research Institute, University of Washington. The program does both, a linear discriminant function (LDF) analysis with error correction (Cook 1982), and a maximum likelihood estimate (MLE) analysis estimating the proportion of fish in the mixture from each of the two baseline groups along with standard deviation estimates. The estimates of Lyons Ferry and mid-Columbia River fall chinook in the Snake River sample are given in Table 6. 
Table 6. The estimated percentage of Lyons Ferry and mid-Columbia fall chinook in the Snake River adult sample $(\mathbf{n}=42)$.

\begin{tabular}{||l|c|c||}
\hline \multirow{2}{*}{ Estimation Method } & \multicolumn{2}{|c||}{ Estimated $\%(\mathrm{sd})$} \\
\cline { 2 - 3 } & Lyons Ferry & Mid-Columbia River \\
\hline \hline Linear Discriminant & $15(23)$ & $85(23 \mathrm{j}$ \\
\hline $\begin{array}{l}\text { Maximum Likelihood } \\
\text { Estimate }\end{array}$ & $03(20)$ & $97(20)$ \\
\hline \hline
\end{tabular}

The relatively low classification accuracy between the two baseline groups results in the large standard deviation (sd) values. This is also the reason for the differences in estimated percentages between the estimation techniques. While there is a difference of $12 \%$ between the LDF and MLE estimates, they are not significantly different. From these data our conclusion is that a high proportion of fish in the Snake River adult sample are of mid-Columbia River origin. However, given the limits of the model's accuracy and small sample size it is not possible to be more conclusive.

The a posteriori probabilities of group membership for individual fish are given in Table 7. The fish number is listed in the first column followed by the probability a fish belongs to the LFH group followed by the probability of membership in the mid-Columbia River group. This model does not allow a great deal to be learned from these data for most of the fish because of the similarities between the two baselines. The majority of probabilities range from 0.3 to 0.7 with only 12 of 42 values falling outside that range. Those fish with the higher values are highlighted in Table 7.

One of these 12 fish (label \# 92FF-17), however, was a recovery upstream of the Salmon River (River $\mathrm{km}$ 320) and classified as a mid-Columbia fish. This fish was also a spawned female and again, it does not support spatial spawning separation.

This genetic analysis was also used on the fall chinook salmon that returned to Dworshak National Fish Hatchery. Seven of the 9 fish that returned were spawned. However, a posteriori probabilities indicated both females (label \# 92 FF-42 and label \# 92 FF-47) which were spawned, were most likely of mid-Columbia origin (Table 7). This determination allowed NMFS and USFWS to decide to not include these fish as part of the evolutionarily significant unit (ESU) of threatened Snake River fall chinook.

Collection of PIT tagged juveniles at LGR was not very successful in 1992. Only 16 recoveries were made that could be used to form a genetic baseline to characterize wild Snake River fall chinook. This was because the PIT tag separator was inoperable during peak migration. This problem has been fixed, and we hope to be more successful in 1993. Fortunately, in 1991, 49 individuals were recovered from the 1990 brood which had been previously captured and tagged by USFWS crews. When the 49 were genetically analyzed (by MLE, using fall, spring and summer run baseline stocks) as a group the analysis indicated there were probably 2-4 spring/summer chinook in the sample. WDF Genetics Unit staff visually examined the genotypes at 28 variable loci for the 49 juveniles and dropped three fish from the sample that stood out as typical 
Table 7. The a posteriori probability values for membership to two baseline stocks of individual recoveries are given based on genetic data. Probability values outside of the 0.3 to 0.7 are highlighted and are somewhat dependable as indicators of stock origin.

\begin{tabular}{|c|c|c|c|c|c|}
\hline & & River & & Frobability of & Membership \\
\hline Label \# & Location & $\mathrm{km}$. & Sex & Lyons Ferry & Upper Columbia \\
\hline $92 \mathrm{FF}-1$ & Gr.Ronde & & $\mathrm{F}$ & 0.670 & 0.330 \\
\hline $92 \mathrm{FF}-2$ & Snake & 311 & $\mathrm{~F}$ & 0.510 & 0.490 \\
\hline $92 F F-3$ & Imnaha & & $F$ & 0.503 & 0.497 \\
\hline $92 F F-4$ & Imnaha & & $F$ & 0.458 & 0.542 \\
\hline $92 \mathrm{FF}-5$ & Gr.Ronde & & $F$ & 0.301 & 0.699 \\
\hline $92 F F-6$ & Gr.Ronde & & $F$ & 0.645 & 0.355 \\
\hline $92 \mathrm{FF}-7$ & Snake & 245 & $F$ & 0.645 & 0.355 \\
\hline 92FF-B & Snake & 245 & $\mathbf{F}$ & 0.177 & 0.823 \\
\hline $92 \mathrm{FF}-9$ & Dworshak & & $M$ & 0.555 & 0.445 \\
\hline $92 \mathrm{FF}-10$ & Snake & 261 & $F$ & 0.296 & 0.704 \\
\hline $92 \mathrm{FF}-11$ & Snake & 259 & $M$ & 0.645 & 0.355 \\
\hline $92 \mathrm{FF}-12$ & Snake & 245 & $\mathrm{~F}$ & 0.317 & 0.683 \\
\hline $92 \mathrm{FF}-13$ & Snake & 245 & $\mathrm{~F}$ & 0.319 & 0.681 \\
\hline $92 F F-14$ & Snake & 261 & $M$ & 0.165 & 0.835 \\
\hline $92 \mathrm{FF}-15$ & Snake & 261 & $F$ & 0.555 & 0.445 \\
\hline $92 \mathrm{FF}-16$ & Snake & 258 & $M$ & 0.319 & 0.681 \\
\hline $92 \mathrm{FF} \cdot 17$ & Snake & 320 & $F$ & 0.222 & 0.778 \\
\hline $92 F F-21$ & Clearwater & & $M$ & 0.296 & 0.704 \\
\hline $92 F F-22$ & Clearwater & & $F$ & 0.237 & 0.763 \\
\hline $92 F F-23$ & Clearwater & & $F$ & 0.295 & 0.705 \\
\hline $92 F F-24$ & Clearwater & & $F$ & 0.477 & 0.523 \\
\hline $92 \mathrm{FF}-25$ & Snake & 245 & $F$ & 0.645 & 0.355 \\
\hline $92 F F-31$ & Snake & 245 & $F$ & 0.814 & 0.186 \\
\hline $92 \mathrm{FF}-32$ & Snake & 245 & $M$ & 0.381 & 0.619 \\
\hline $92 F F-41$ & Oworshak & & $M$ & 0.555 & 0.445 \\
\hline $92 F F-42$ & Dworshak & & $F$ & 0.242 & 0.758 \\
\hline $92 F F-43$ & Dworshak & & $M$ & 0.457 & 0.543 \\
\hline $92 F F-44$ & Dworshak & & $M$ & 0.643 & 0.357 \\
\hline $92 F F-45$ & Dworshak & & $M$ & 0.365 & 0.635 \\
\hline $92 F F-46$ & Dworshak & & $M$ & 0.486 & 0.514 \\
\hline $92 F F-47$ & Dworshak & & $F$ & 0.302 & 0.698 \\
\hline $92 \mathrm{FF}-48$ & Dworshak & & $M$ & 0.294 & 0.706 \\
\hline $92 \mathrm{FF}-56$ & Snake & 245 & $F$ & 0.555 & 0.445 \\
\hline $92 F F-57$ & Snake & 245 & $M$ & 0.177 & 0.823 \\
\hline $92 F F-58$ & Snake & 245 & $F$ & 0.454 & 0.546 \\
\hline $92 F F-59$ & Snake & 245 & $F$ & 0.39 & 0.61 \\
\hline $92 F F-60$ & Snake & 332 & $F$ & 0.645 & 0.355 \\
\hline $92 F F-61$ & Clearwater & & $F$ & 0.382 & 0.618 \\
\hline $92 F F-62$ & Clearwater & & $F$ & 0.454 & 0.546 \\
\hline $92 F F-63$ & Clearwater & & $F$ & 0.727 & 0.273 \\
\hline $92 F F-81$ & Clearwater & & $F$ & 0.477 & 2.523 \\
\hline $92 F F-82$ & Clearwater & $i$ & $F$ & 0.555 & 2.445 \\
\hline
\end{tabular}


Figure 1. Analysis of genetic distance among chinook stocks from the Upper Columbia and Snake Rivers. Dendrogram was constructed using 30 loci and unweighted pair group method with Cavalli-Sforza \& Edwards (1967) chord distance.

\section{GENETIC DISTANCE}

$\begin{array}{lllllll}0.20 & 0.17 & 0.13 & 0.10 & 0.07 & 0.03 & 0.00\end{array}$

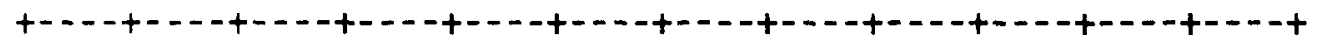

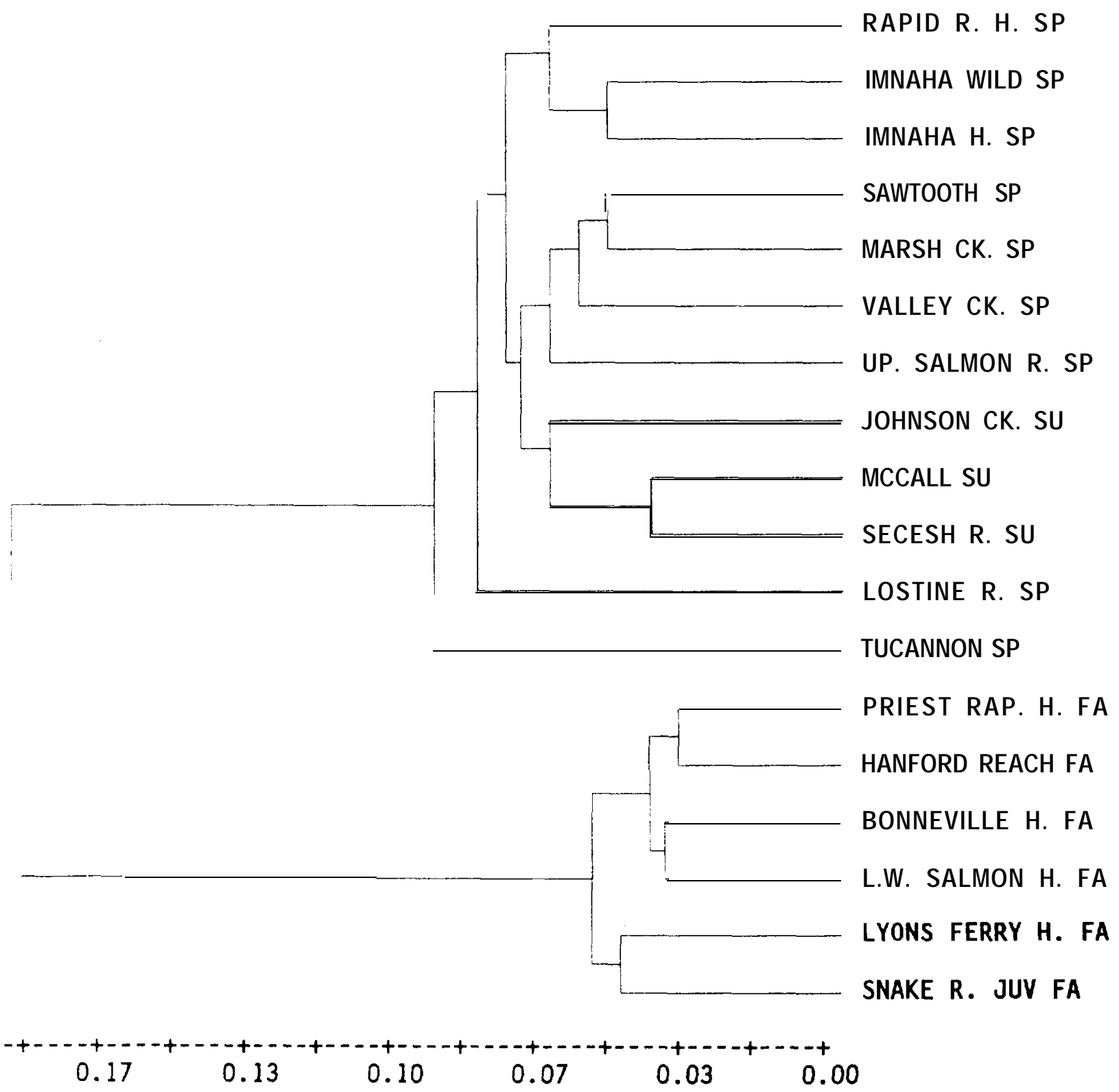


spring/summer genetic profiles. This was accomplishable because the allele frequencies of several variable loci are so different between mid-Columbia/Lyons Ferry fall chinook and Snake River spring/summer chinook. When the 46 remaining fish were re-analyzed by MLE, the stock composition estimate changed to 100 percent fall chinook. These 46 juveniles were then used to represent a genetic baseline of wild Snake River fall chinook. This baseline collection was used in a cluster analysis (un-weighted pair group method) based on the genetic distance, Cavalli-Sfor'za and Edwards (1967) chord distance, among Snake and mid-Columbia spring, summer, and fall stocks. The dendogram resulting from the cluster analysis is shown in Figure 1. The wild 1990 brood Snake River juveniles clustered with, and showed no significant genetic difference (G-test, 30 loci, $\mathrm{P} \geq .05$ ) from, the LFH baseline. Significant differences did appear between these two chinook salmon baselines and the mid-Columbia fall chinook salmon baselines. This information coupled with the information from Bugert et al. (1991) which shows no significant difference between the original Snake River broodstock taken at IHR starting in 1977 and the present LFH broodstock is very encouraging because that indicates that the intent of the Snake River Wild Eggbank Program has been maintained. The implication of this is that LFH stock can be considered as an option for rebuilding the threatened ESU Snake River fall chinook salmon population. In fact, because of the hatchery practices at LFH where genetic integrity is being maintained by elimination of all nonLFH from the broodstock fish, the LFH fish may be a more true genetic representation of the original wild population than what is spawning in the wild at present. 


\section{REFERENCES}

Brown, M. B., L. Engelman, J. W. Frane, M. A. Hill, R. I. Jenrick, and J. D. Toporek. 1983. BMDP statistical software. University of California Press, Berkeley. 733pp.

Bugert, R.. C. Busack, G. Mended, K. Petersen, D. Marback, L. Ross and J. Dedloff. 1991. 1990 Lower Snake River Compensation Plan, Lyons Ferry fall chinook salmon hatchery program. 1990 evaluation report to U.S. Fish and Wildlife Service. Report AFF 1/L SR-91-15 Cooperative Agreement 14-1600001-90525. Washington Department of Fisheries.

Cavalli - Sforza, L. L., and S. W. F. Edwards. 1967. Phylogenetic analysis: models and estimation precedures. Evolution 21: $550-570$.

Cook, R. C. 1982. Stock identification of sockeye salmon (Onconhynchus nerka) with scale pattern recognition. Canadian Journal of Fisheries and Aquatic Sciences 39(4):611-617

Cooney, T. 1991. Estimation of Snake River fall chinook returns to Ice Harbor, LF Hatchery, and over Lower Granite. Washington Department of Fisheries memorandum, May 7, 1991.

Marshall, A. R., M. Miller, C. Busack, and S. Phelps. 1991. Genetic stock identification analysis of three 1990 Washington ocean and Strait of Juan de Fuca chinook salmon fisheries. GSI summary report 91-1. Washington Department of Fisheries.

TAC. 1992 (Technical Advisory Committee to Columbia River Compact). Biological assessment of the impacts of anticipated 1992 summer and fall season Columbia River Fisheries on listed Snake River species under the Endangered Species Act. May 1992. 